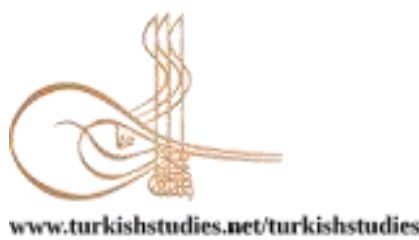

Turkish Studies

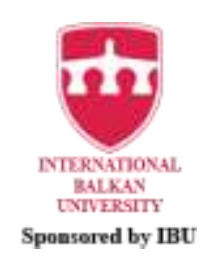

\title{
Okuma Kültürünün Oluşması Sürecinde Türkçe Öğretmenlerinin Yeri ve Önemi
}

\author{
The Place and Importance of Turkish Teachers in The Process of Formation of Reading Culture
}

\author{
Saadet Ünlü* - Nigar İpek Eğilmez ${ }^{* *}$
}

\begin{abstract}
The current study was conducted to explore the place and importance of Turkish teachers in the process of formation of reading culture. In the study, the concept of reading culture, the process of formation of reading culture and the elements affecting the process of formation of reading culture have been addressed. The study employed the survey model. The population of the study is comprised of the Turkish teachers working in the secondary schools located in the central and surrounding districts of the city of Muğla in the 2017-2018 school year. The sample of the study consists of 142 Turkish teachers selected from among the population by using the stratified random sampling method. As the data collection tool, the Questionnaire of Activities for Imparting Reading Culture to Students developed after seeking expert opinions was used. The data collected through the measurement tools were analyzed by using the content analysis method. The responses given by the Turkish teachers to the questionnaire items were coded and classified, and the classified data are presented in tables after their percentage and frequency calculations have been made. The items to which teachers provided more than one response were analyzed in SPSS program package and are presented in tables. Moreover, direct quotations are made from the teachers' opinions and are given under the tables. The findings of the study are presented under three main headings; "Findings about the Reading Culture of the Turkish Teachers", "Activities Conducted by the Turkish Teachers to Develop Reading Culture in Students" and "Suggestions Made by the Turkish Teachers for Students to Turn Reading into a Culture". The results of the study are presented under three main headings; "Results and Discussion related to the Findings about the Reading Culture of the Turkish Teachers", "Results and Discussion related to the Activities Conducted by the Turkish Teachers to Develop Reading Culture in Students" and "Results and Discussion related to the Findings about the Suggestions Made by the Turkish Teachers for Students to Turn Reading into a Culture". In light of the results of the study, suggestions are made for implementers (state, educational institutions, teachers) and researchers.
\end{abstract}

Structured Abstract: The development level of a society is directly proportional to the importance it attaches to reading. Only reading individuals can create the structure of a democratic, peaceful, sensitive and modern society. An individual who reads is an individual who knows the past of his/her country and can direct the

\footnotetext{
* Türkçe Öğretmeni, Gökçe Zeynep Gönen Ortaokulu

Turkish Teacher Gökçe Zeynep Gönen Middle School

ORCID 0000-0002-8633-8568

hepbahtiyar@hotmail.com

** Doç. Dr., Muğla Sıtkı Koçman Üniversitesi, Eğitim Fakültesi, Türkçe Bölümü

Assoc. Prof., Muğla Sitkı Koçman University

ORCID 0000-0003-4266-5935

nigaripek@mu.edu.tr

Cite as/ Atıf: Ünlü, S. \& Eğilmez, N. İ. (2021). Okuma kültürünün oluşması sürecinde Türkçe öğretmenlerinin yeri ve önemi. Turkish Studies, 16(4), 1365-1404. https://dx.doi.org/10.7827/TurkishStudies.49998

Received/Geliş: 18 March/Mart 2021

Accepted/Kabul: 25 August/Ağustos 2021

Checked by plagiarism software

Published/Yayın: 30 August/Ağustos 2021

CC BY-NC 4.0
} 
future of his/her country in line with this past. The results of the international exams such as PISA and PIRLS and the results of the survey conducted by the Platform of Making Reading Culture More Widespread (OKUYAY) in our country have revealed that the required importance has not been attached to reading in Turkey. For this reason, the act of reading should be internalized and turned into a culture in our society. The most important responsibility in this regard falls onto the shoulders of families and teachers. Thus, the current study aimed to investigate the place and importance of Turkish teachers in the process of formation of a reading culture. To this end, answers to the following questions were sought: What is the state of reading of the Turkish teachers? What are the characteristics of the Turkish teachers regarding their reading culture? What activities do the Turkish teachers perform to impart a reading culture to students? What are the suggestions made by the Turkish teachers to develop the reading culture of their students?

The current study employed the survey model as it attempted to describe an event, individual or object in its natural conditions as it is. The population of the study is comprised of the Turkish teachers working in the secondary schools located in the central and surrounding districts of the city of Muğla in the 2017-2018 school year. The sample of the study consists of 142 Turkish teachers selected from among the population by using the stratified random sampling method. The data of the current study were collected by visiting the secondary schools where the Turkish teachers in the sample were working and administering a questionnaire to them. The responses given to the questionnaire items by the teachers were analyzed by means of the content analysis method. The responses given by the Turkish teachers to the questionnaire items were examined, coded and classified into certain categories based on these codes. The classified data are presented in tables after their percentage and frequency calculations have been made. In order reflect the opinions of the participants more effectively, direct quotations from the teachers' responses are given. Moreover, the items to which the participating teachers gave more than one answer were analyzed in SPSS program package

The Turkish teachers were found to be reading a lot and the materials they most prefer to read are books, the literary genre they most prefer to read is novel and the type of the book they most prefer to read is literary books and they are individuals who are aware of the characteristics of their reading culture. When the Reading Culture Map of Turkey prepared by the Ministry of Culture and Tourism (2011) is examined, it is seen that the book $(54 \%)$ is the most read material. It was seen that the Turkish teachers could organize activities in line with the possibilities to develop their students' reading culture, that they thought in the process of students' acquiring a reading culture, students' interests, levels, family members and teachers' being a role model and activities organized on reading (fairs, talks, drama, debate, signature days, book days etc.) are important and that they made suggestions in line with these thoughts. In the Reading Culture and Awareness Workshop organized by the Ministry of Development (2017) within the context of the Kop Is Reading Project, a great emphasis was put on the problem of lack of socio-cultural activities in rural areas and suggestions were made such as organizing book fairs to overcome this problem, organizing events where readers and writers can come together and including activities related to reading and books in local festivals.

In the current study, it was concluded that the Turkish teachers are aware of the characteristics of their reading culture, that they are effective in the process of developing a reading culture in students, that they can become a role model to their students and that they can help their students develop their reading culture with the activities they conduct.

In light of the findings of the current study, the following suggestions can be made for implementers (state, educational institutions, teachers): Courses can be organized to make students love reading through different methods and techniques, the number of libraries can be increased, libraries can be improved and can be made more attractive, additional budgets can be allocated to libraries at schools, reading zones can be created in different places (bus, metro, prison, park, etc.), book fairs, signature days, author and poet conversions can be organized across the country, taxes and prices of books can be decreased, scenes encouraging reading can be shown in TV series, documentaries can be shot to make students love reading, the contributions of individuals reading to the society can be emphasized, seminars can be held to inform families about how to teach reading to their children and Turkish teachers can organize different activities to develop students' reading culture. And the following suggestions can be made for researchers: Further research can be conducted to investigate the effect of library use on the formation of reading culture considering the importance of libraries in the process of formation of reading culture. Research has revealed that reading culture starts to form in the family at early ages. In this respect, future research can investigate what families can do to develop a reading culture in their children. It is generally assumed that secondary school students should have a reading culture. 
Thus, it can be investigated whether secondary school students have developed a reading culture and what can be done to develop a reading culture in students.

Keywords: Turkish education, reading, reading culture, Turkish teacher, middle school

Öz: Bu çalışma; okuma kültürü oluşturma sürecinde Türkçe öğretmenlerinin yeri ve önemini araştırmak amacıyla yapılmıştır. Çalışmada; okuma kültürü kavramı, okuma kültürü oluşturma süreci, okuma kültürü oluşturma sürecini etkileyen etmenler üzerinde durulmuştur.Araştırmada tarama modeli kullanılmıştır. Araştırmanın evrenini 2017-2018 eğitim öğretim yılında, Muğla il merkezi ve ilçelerinde görev yapmakta olan Türkçe öğretmenleri oluşturmaktadır. Araştırmanın örneklemini ise Muğla ilinin farklı ilçelerinde görev yapan ve tabakalı rastgele örnekleme yöntemi ile seçilmiş 142 Türkçe öğretmeni oluşturmaktadır. Veri toplama aracı olarak uzman görüşü alınarak geliştirilen Öğrencilere Okuma Kültürü Edindirmek Amacıyla Yapılan Etkinlikler Anketi kullanılmıştır. Ölçme araçlarından elde edilen veriler içerik analizi yöntemi kullanılarak çözümlenmiştir. Türkçe öğretmenlerinin anket sorularına verdikleri cevaplar kodlanarak sınıflandırılmış, sınıflandırılan veriler yüzde ve frekans hesapları yapılarak tablolar halinde sunulmuştur. Öğretmenlerin birden fazla yanıt verdiği sorular ise SPSS programı ile çözümlenmiş ve tablolar halinde sunulmuştur. Ayrıca tabloların altında öğretmen görüşlerinden alıntılara yer verilmiştir. Araştırmanın bulguları; "Türkçe Öğretmenlerinin Okuma Kültürlerine İlişkin Tespitler”, “Öğrencilerde Okuma Kültürü Oluşturabilmek Adına Türkçe Öğretmenleri Tarafından Yapılan Etkinlikler" ve "Öğrencilerin Okumayı Bir Kültür Haline Getirebilmeleri İçin Türkçe Öğretmenlerinden Öneriler” olmak üzere üç ana başlık altında sunulmuştur. Araştırma sonuçları; "Türkçe Öğretmenlerinin Okuma Kültürlerine Dair Elde Edilen Tespitlere İlişkin Sonuçlar ve Tartışmalar”, "Öğrencilerde Okuma Kültürü Oluşturabilmek Adına Türkçe Öğretmenleri Tarafından Yapılan Etkinliklere Dair Elde Edilen Tespitlere Dair Sonuçlar ve Tartışmalar” ve "Öğrencilerin Okumayı Bir Kültür Haline Getirebilmeleri İçin Türkçe Öğretmenlerinin Verdiği Önerilerden Elde Edilen Tespitlere İlişkin Sonuçlar ve Öneriler" olmak üzere üç ana başlık altında sunulmuştur. Araştırma sonuçlarına göre; uygulayıcılara (devlet, eğitim kurumları, öğretmen) ve araştırmacılara yönelik öneriler sunulmuştur.

Anahtar kelimeler: Türkçe eğitimi, okuma, okuma kültürü, Türkçe öğretmeni, ortaokul

\section{Giriş}

Gelişmiş ve modern toplumlar okumaya oldukça önem vermektedir. Çünkü geçmiş, bugün ve gelecek arasında sağlıklı bir düşünce köprüsü kurabilmek, geçmiş yaşantıları yorumlayabilmek ve nesiller araşı kültürel aktarımı sağlayabilmek ancak okuyan bireylerden oluşmuş bir toplum ile sağlanabilir (İpek Eğilmez ve Özşavli, 2018: 731). Okumayı öğrenen çocuk toplumun ortak bilgilerine ve değerlerine kitaplar aracılığı ile katılır, bu sayede ortak geçmişi tanır ve her okuma ile bu geçmişi yeniler. Bu anlamda okumayı öğrenmek, bir tür üyeliğe kabul törenidir denilebilir (Manguel, 2002). Bu yönü ile okuma başlı başına bir okuldur (Gündüz ve Şimşek, 2011). Okumak sadece bir iş, bir beceri değil bir yaşam biçimidir aynı zamanda (Kasap, 2019: 18). Bu sebeple okumayı bir kültür haline getirmeli; okumanın önemini okulda, çarşıda, pazarda halka anlatarak nitelikli okurlara ulaşmalıyız (Ungan, 2008: 226).

PISA verilerine göre Türkiye'nin okuma alanı puan sıralaması, katılan ülkeler arasında 2009 y1lında 39, 2012 yılında 42, 2015 yılında 50'dir (MEB Ölçme Değerlendirme ve Sınav Hizmetleri Genel Müdürlüğü, 2015). 2001 yılında, ülkemiz PIRLS testine de katılmıştır. Test sonuçlarına bakıldığında Türkiye'nin 35 katılımcı ülke arasında 28. sırada yer aldığı görülmektedir (Çocuk Vakfı, 2006). Sonuçlar ülkemizin okuma konusunda dünya ortalamasının oldukça altında kaldığını göstermektedir. OKUYAY'ın (2019) 15 yaş üstü nüfusun okuma alışkanlıklarını, kitap seçme, okuma ve satın alma davranışlarını, sosyal medya, televizyon vb. alışkanlıklarını anlamak; kitaba erişim, kütüphane kullanımı, fuar ziyareti konularındaki düşüncelerini öğrenmek ve okuma kültürünü yaygınlaştırma konusunda yapılması gerekenleri ortaya koyabilmek amaciyla gerçekleştirdiği Türkiye Okuma Kültürü Araştırması sonuçlarına göre ise okuma kümeleri dağılımı şu şekildedir: okuyanlar \%42,3, okuyabilirler $\% 18,8$, eskiden okuyanlar $\% 16,4$, okumayanlar $\% 22,5$. 
$\mathrm{Bu}$ sonuçlarda görülmektedir ki toplumun yarıdan fazlası okumaktadır. Bu durum bizlere toplumumuz tarafindan okumaya gereken önemin verilmediğini ve toplumda yerleşik bir okuma kültürü olmadığını göstermektedir.

Y1lmaz’a (2009: 134) göre okuma kültürü bir bireyin, bir toplumsal grubun okuma ile ilişkilerinin düzeyini ve niteliğini gösterir. Yani bahsedilen bireyin ya da topluma ait yaşam biçiminin okumaya yansımasıdır. Kısaca okuma kültürü, okumaya ilişkin bireysel ve toplumsal bir yaşama biçimidir. Sever' e (2007: 108) göre okuma kültürünü, “yazılı kültür ürünlerinin dünyasıyla tanışmış; tanıştı̆̆ bu dünyanın kendine sunduğu iletileri paylaşma, sınama, sorgulama yeterliğine ulaşmış; bunların sunduğu olanaklarla yaşamayı alışkanlık haline getirmiş bireylerin edinmiş olduğu kültür" dür. İnce Samur'a (2016: 2) göre okuma kültürü, erken çocukluktan başlayarak duyarlı ve bilinçli çabalarla oluşturulması gereken hayati bir olgudur. Bu bağlamda okuma kültürü oluşturma, bireyin; gizilgüçlerini ortaya çıkaran, estetik duyarlıkla örülmüş yazılı ve görsel kültür ürünleriyle buluşması, başka bir ifadeyle okuma eylemini yaşam felsefesi olarak içselleştirmesiyle ilgili bir süreçtir. Bir toplumda okuma kültürünün varlığının en önemli göstergesi okumanın gündelik yaşam içerisinde yer almasıdır.

İnce Samur'a (2014: 2) göre bir kültürün yerleşmesi dil ve iletişim ile olur. Doğduğumuz andan itibaren dil ve iletişim ile hayatımız hep iç içedir. Dolayısı ile okuma kültürü edindirme süreci de doğumla başlayıp yaşam boyu devam eder. Okuma kültürü edindirme sürecinde 0-14 yaş kritik dönemdir. Çünkü birçok beceri bu yaşlarda kazanılır. İnsanın kişiliği, yaşam tarzı ve hayata bakışı yine bu dönemlerde şekillenir. İnce Samur (2014: 17-18) okuma kültürü oluşturma basamaklarını şu şekilde tanımlamıștır:

Okulöncesi Dönem

Görsel Okuma Dönemi (Görsel ve Dilsel Uyaranlarla İletişim Kurma)

1) Çocukların Kitapla Tanıştırılması (0-2 yaş)

2) Çocukların Kitaplarla Arkadaşlık Kurması (2-4 yaş)

3) Çocuklarda Kitap Sevgisinin Oluşturulması (4-6 yaş)

Illkokul Dönemi

Görsel Okumadan Dilsel Okumaya Geçiş Dönemi

4) Çocuklara Okuma Yazma Becerisinin Kazandırılması (6-8 yaş)

5) Çocuklara Okuma Alışkanlığı Kazandırılması (8-10 yaş)

Ortaokul Dönemi Dilsel Okumadan Eleştirel Okuma, İleme, Dinlemeye Geçiş Dönemi

6) Çocuklara Eleştirel Okuma, İzleme, Dinleme Becerisinin Edindirilmesi (10-12 yaş)

7) Çocuklara Okuma Kültürü Edindirilmesi (12-14 yaş).

Sever'e (2010) göre ise okuma kültürü birbirine bağımlı ve birbirini bütünleyen ardışık bir süreçtir. Bu sürecin ilk basamağı dinleme alışkanlığı, ikinci basamağı okuma yazma becerisi, üçüncü basamağı okuma alışkanlığı, dördüncü basamağı eleştirel okuma, beşinci ve son basamağı ise evrensel okur-yazarlık becerisidir.

Körkuyu (2014) okuma kültürü oluşturma sürecini etkileyen temel unsurları aile ve okul olarak ele almıştır. Körkuyu'nun sınıflandırmasından yola çıkılarak daha özele inildiğinde bireyin okuma kültürü oluşturma sürecini etkileyen; öğretmen, Türkçe dersi programı, Türkçe dersi, ilgi, yaş, cinsiyet, kitap, çocuk edebiyatı, kitaplık, kütüphane, süreli yayınlar, medya, sosyal medya, internet, ülkenin gelişmişlik düzeyi, toplumsal ve siyasi yapı, arkadaş çevresi gibi daha birçok etmen bulunmaktadır. Okuma kültürünün temelleri ailede atılmakta, okullarda öğretmenlerin elinde şekillenmektedir. Bir ülkede gelecek nesillerin yetişmesinden, eğitimin odak noktasında olan öğretmenler sorumludur. Okuma kültürü oluşturma sürecinde de öğretmenler görevlerini en iyi şekilde yerine getirmelidirler. Öğretmenlerin bu görevlerini başarıyla yerine getirebilmeleri için öncelikle kendilerinin okuma kültürüne sahip bireyler olmaları gerekmektedir ki öğrencilerine rol model olabilsinler. Körkuyu'ya (2014) göre de öğretmenin okuma kültürü oluşturabilme sürecinde rol alabilmesi için öncelikle kendisinde bu kültürün oluşmuş olması ve oluşma süreci ile ilgili bilgi 
sahibi olması gerekmektedir. Bu süreçte öğretmenin çocuğa rol model olması önemlidir. Ayrıca çocuğun düzeyine, ilgi ve ihtiyaçlarına uygun doğru yönlendirme ve desteklemeyi yapabilmesi öğretmenin bu konudaki bilgi birikimine bağlıdır. Bu nedenle bu çalışmada öğretmenlerin okuma kültürü oluşturma sürecindeki önemi dikkate alınarak ortaokul kademesinde, Türkçe öğretmenlerinin öğrencilerinde okuma kültürü oluşturma sürecine etkisi üzerinde durulmuştur.

Yerli ve yabancı literatürde okuma kültürü alanında oldukça az sayıda çalışma bulunmaktadır. Bu nedenle bu çalışmanın, "okuma kültürü" konusunda uygulamalı bir çalışma olarak alana katkı sağlayacağı düşünülmektedir. Yapılan araştırma sonucunda elde edilen verilere göre, çocuklarda okuma kültürü oluşturabilmek adına neler yapılabileceğine ilişkin yeni fikirler ve uygulamalar ortaya çıkabilir. Ortaya çıkan yeni fikirler bu konuda yapılacak çalışmalara 1 şık tutabilir.

Çalışmanın genel amac1; okuma kültürü oluşturma sürecinde, Türkçe öğretmenlerinin yeri ve önemini incelemektir. Bu genel amaç doğrultusunda şu alt amaçlara cevap aranmıştır:

a) Türkçe öğretmenlerinin okuma durumları nedir?

b) Türkçe öğretmenlerinin okuma kültürüne ilişkin özellikleri nelerdir?

c)Türkçe öğretmenleri öğrencilerine okuma kültürü oluşturmak için ne gibi uygulamalar yapmaktadir? nelerdir?

d) Türkçe öğretmenlerinin öğrencilerin okuma kültürlerini geliştirmeye yönelik önerileri

\section{Yöntem}

\section{Araştırmanın Modeli (Deseni)}

$\mathrm{Bu}$ araştırmada tarama modelinden yararlanılmıştır. Tarama modelleri, geçmişte ya da hâlen var olan bir durumu var olduğu şekliyle betimlemeyi amaçlayan araştırma yaklaşımlarıdır. Bu nedenle araştırmalara konu olan herhangi bir olay, birey ya da nesne kendi koşulları içinde ve olduğu gibi tanımlanmaya çalış1ır (Karasar, 1999: 77). Bu çalışmada da araştırmaya konu olan olay, birey ya da nesne kendi koşulları içinde ve olduğu gibi tanımlanmaya çalışılmıştır.

\section{Evren ve Örneklem}

Araştırmanın evrenini Muğla il ve ilçelerinde yer alan ortaokullarda 2017-2018 eğitim öğretim yılı içinde görev yapmakta olan 540 Türkçe öğretmeni oluşturmaktadır. Araştırmanın örneklemini ise farklı ilçelerde görev yapan ve tabakalı rastgele örnekleme yöntemi ile seçilmiş 142 Türkçe öğretmeni oluşturmaktadır. Tabakalı örnekleme, "sınırları saptanmış bir evrende alt tabakalar veya alt birim gruplarının var olduğu durumlarda kullanılan" bir örnekleme yöntemidir (Yıldırım ve Şimşek, 2005a: 105).

Çalışmada; Menteşe ilçesinden 17, Fethiye ilçesinden 17, Seydikemer ilçesinden 14, Yatağan ilçesinden 12, Ortaca ilçesinden 12, Dalaman ilçesinden 12, Milas ilçesinden 12, Marmaris ilçesinden 10, Köyceğiz ilçesinden 9, Ula ilçesinden 9, Datça ilçesinden 7, Kavaklıdere ilçesinden 7 ve Bodrum ilçesinden 4 adet Türkçe öğretmenine ulaşılmıştır.

Araştırmaya katılan öğretmenlerin \%65,5'i kadın, \%34,5'i erkek katılımcılardan oluşmaktadır. Yine araştırmaya katılan öğretmenlerin yaş aralıklarına bakıldığında; \%21,1'inin 2130 yaş, $\% 56,3$ 'ünün $31-40$ yaş, $\% 15,5$ 'inin $41-50$ yaş, $\% 7$ 'sinin ise 50 yaş ve üzeri öğretmenler olduğu görülmüştür. Araştırmaya katılan Türkçe öğretmenlerinin \%16,2'sinin 1-5 yıl kıdem, \%19,7'sinin 6-10 yıl kıdem, \%64,1'inin 11 yıl ve üzeri kıdem aralıklarında çalışmaktadır. Bulgular yorumlanırken ögretmenlerin kıdemleri göz önüne alınarak değerlendirme yapılmıştır.

Araştırmaya katılan Türkçe öğretmenlerinin eğitim durumlarına bakıldığında ise; \%96,5'inin lisans, \%3,5'inin ise yüksek lisans mezunu olduğu görülmüştür. Öğretmenlerin mezun olduklar1 bölümlere bakıldığında; \%71,1'inin Türkçe öğretmenliği bölümü, \%13,4'ünün Türk dili ve edebiyatı 
öğretmenliği bölümü, \%11,3'ünün Türk dili ve edebiyatı bölümü, \%2,1'inin sınıf öğretmenliği bölümü, \%1,4'ünün çağdaş Türk lehçeleri ve edebiyatları bölümü, \%0,7'sinin ise Fransızca öğretmenliği bölümünden mezun olduğu görülmüştür.

\section{Verilerin Toplanması}

Uygulama 2017-2018 Eğitim Öğretim yılının 2. döneminde Muğla il merkezi ve ilçelerinde yer alan ortaokullara gidilerek, bu okullarda görev yapmakta olan Türkçe öğretmenlerine anket uygulanarak gerçekleştirilmiştir.

\section{Veri Toplama Araçları}

$\mathrm{Bu}$ araştırma kapsamında Türkçe öğretmenlerine bir anket uygulanmıştır. Anket geliştirilirken öncelikle konu ile ilgili oldukça ayrıntılı bir alan taraması yapılmış, okuma kültürünü etkileyen etmenler ve okuma kültürü edinmiş bireyin özellikleri tespit edilmiştir. Tüm bu verilerden yola çıkarak dört alt bölümden oluşan "Öğrencilere Okuma Kültürü Edindirmek İçin Yapılan Etkinlikler Öğretmen Anketi” hazırlanmıştır. Hazırlanan ankette 13 adet açık uçlu soru, 10 adet evethayır seçenekli soru, 7 adet seçenekli soru vardır. Hazırlanan anket soruları 4 alan uzmanı tarafindan incelenmiş ve onların da önerileri alınarak düzenlenmiş ve geliştirilmiştir.

\section{Verilerin Analizi}

Öğretmenlerin yanıtladığı anket soruları, içerik analizi yöntemi ile çözümlenmiştir. İçerik analizinin amacı toplanan verileri açıklayabilecek kavramlara ve ilişkilere ulaşmak için birbirine benzeyen verilerin belirli kavramlar ve temalar çerçevesinde bir araya getirilmesi ve bunların okuyucun anlayabileceği şekilde yorumlanıp düzenlenmesidir (Yıldırım ve Şimşek, 2005b: 227). Türkçe öğretmenlerinin anket sorularına verdikleri cevaplar bu doğrultuda incelemiş, kodlanmış ve bu kodlara bağlı olarak belirli kategorilere ayrılarak sınıflandırılmıştır. Sınıflandırılan veriler yüzde ve frekans hesapları yapılarak tablolar haline sunulmuş̧ur. Ayrıca ankete katılanların düşüncelerini daha etkili bir şekilde yansıtabilmek için öğretmen cevaplarından doğrudan alıntılara yer verilmiştir.

Verilerin güvenirliğinin tespit edilebilmesi için farklı zaman dilimlerinde veriler iki kez gözden geçirilmiştir. Güvenirliğin hesaplanabilmesi için Miles ve Huberman'ın (2015: 64) önerdiği güvenirlik formülü kullanılmıştır.

\section{Güvenirlik = Görüş Birliği Sayıs1/Görüş Birliği + Görüş Ayrılığ1 Sayıs1}

Hesaplama sonucunda araştırmanın güvenirliği \%95 olarak belirlenmiş ve bu sonuç araştırmanın güvenirliği için yeterli kabul edilmiştir.

Her kıdem grubunda bulunan öğretmen sayısı farklılık gösterdiğinden tablolar oluşturulurken öğretmenlerin verdikleri cevapların yüzdesi alınmıştır. Bunun yanı sıra seçenekli sorularda öğretmenlerin sorulara birden fazla yanıt verdikleri göz önünde bulundurularak bu yanıtlar SPSS programı ile değerlendirilmiştir. Bu nedenle SPSS programı ile çözümlemesi yapılan sorularda öğretmen sayısı yerine soruya verilen cevap sayısı dikkate alınmış ve tablolar buna göre düzenlenmiştir (Tablo 2, Tablo 3, Tablo 17, Tablo 18).

\section{Bulgular}

Araştırmanın bu bölümünde, elde edilen bulgular sunulmuştur. Bulgular, "Türkçe Öğretmenlerinin Okuma Kültürlerine İlişkin Tespitler", “Öğrencilerde Okuma Kültürü Oluşturabilmek Adına Türkçe Öğretmenleri Tarafından Yapılan Etkinlikler" ve "Öğrencilerin Okumayı Bir Kültür Haline Getirebilmeleri İçin Türkçe Öğretmenlerinden Öneriler” olmak üzere üç ana başlık altında sunulmuştur. 


\section{Türkçe Öğretmenlerinin Okuma Kültürlerine İlişkin Tespitler}

Araştırmanın bu bölümünde birinci ve ikinci alt amaçlara ilişkin bulgular yer almaktadır. Bir başka deyişle Türkçe öğretmenlerinin okuma durumları ve okuma kültürlerine ilişkin özellikleri bu başlık altında ele alınmıştır.

Türkçe öğretmenlerine "Ne sıklıkla okursunuz?" sorusu sorulmuş ve alınan cevaplar tabloda gösterilmiştir.

Tablo 1: Türkçe Öğretmenlerinin Okuma Sıklıkları

\begin{tabular}{|c|c|c|c|c|c|c|c|c|}
\hline \multirow{2}{*}{$\begin{array}{l}\text { Türkçe Öğretmenlerinin } \\
\text { Okuma Sıklıkları }\end{array}$} & \multicolumn{2}{|c|}{ 1-5 Yil Kidem } & \multicolumn{2}{|c|}{ 6-10 Yil Kidem } & \multicolumn{2}{|c|}{11 Yil ve Üzeri Kidem } & \multicolumn{2}{|c|}{ Toplam } \\
\hline & f. & $\%$ & f. & $\%$ & f. & $\%$ & f. & $\%$ \\
\hline Her gün & 15 & 50 & 8 & 34,8 & 38 & 42,2 & 61 & 42,7 \\
\hline Boş zamanlarımda & 5 & 16,7 & 7 & 30,4 & 15 & 16,7 & 27 & 18,9 \\
\hline Ayda bir kitap & 5 & 16,7 & 2 & 8,7 & 12 & 13,3 & 19 & 13,3 \\
\hline Boş & 3 & 10 & 1 & 4,3 & 13 & 14,4 & 17 & 11,9 \\
\hline Ayda iki kitap & 1 & 3,3 & 1 & 4,3 & 8 & 8,9 & 10 & 7 \\
\hline Haftada bir kitap & 1 & 3,3 & 4 & 17,4 & 4 & 4,4 & 9 & 6,3 \\
\hline Toplam & 30 & 100 & 23 & 100 & 90 & 100 & 143 & 100 \\
\hline
\end{tabular}

Tabloya bakıldığında toplamda öğretmenlerin en çok "her gün" $(\% 42,7)$ cevabını verdikleri görülmüştür. Daha sonra "boş zamanlarımda" (\%18,9), "ayda bir kitap" $(13,3)$, "ayda iki kitap" (\%7) cevaplarını vermişlerdir. En az cevap ise "haftada bir kitap" (\%6,3) cevabıdır. Öğretmenlerin $\% 11,9$ u soruyu cevaplamamıştır. Türkçe öğretmenlerine "En çok tercih ettiğiniz okuma materyali nedir?" sorusu sorulmuş ve alınan cevaplar tabloda gösterilmiştir.

Tablo 2: Türkçe Öğretmenlerinin Tercih Ettiği Okuma Materyalleri

\begin{tabular}{|c|c|c|c|c|c|c|c|c|}
\hline \multirow[t]{2}{*}{ Materyaller } & \multicolumn{2}{|c|}{ 1-5 Y1l k1dem } & \multicolumn{2}{|c|}{ 6-10 Y1l Kidem } & \multirow{2}{*}{$\begin{array}{l}11 \quad \mathrm{Y} \\
\text { K1dem } \\
\text { f. }\end{array}$} & \multirow{2}{*}{$\begin{array}{cc}\text { ve } & \text { Üzeri } \\
\% & \\
\end{array}$} & \multicolumn{2}{|c|}{ Toplam } \\
\hline & $\mathrm{f}$. & $\%$ & f. & $\%$ & & & f. & $\%$ \\
\hline Kitap & 22 & 91,6 & 26 & 78,7 & 86 & 71 & 134 & 74,4 \\
\hline Dergi & 2 & 4,2 & 4 & 12,1 & 8 & 6,6 & 14 & 7,7 \\
\hline Gazete & 2 & 4,2 & 3 & 9,2 & 21 & 17,3 & 26 & 14,4 \\
\hline E-kitap & 0 & 0 & 0 & 0 & 4 & 3,3 & 4 & 2,2 \\
\hline $\begin{array}{l}\text { Diğer } \\
\text { (İnternet) }\end{array}$ & 0 & 0 & 0 & 0 & 2 & 1,6 & 2 & 1,1 \\
\hline Toplam & 26 & 100 & 33 & 100 & 121 & 100 & 180 & 100 \\
\hline
\end{tabular}

Türkçe öğretmenlerinin en çok "kitap" $(\% 74,4)$ materyalini okumayı tercih ettiği görülmüştür. Daha sonra "gazete" $(\% 14,4)$, "dergi" $(\% 7,7)$, "e-kitap" $(\% 2,2)$ ve "diğer (internet)" $(\% 1,1)$ cevapları verilmiştir. Kıdem boyutunda bakıldığında, 1-5 yıl kıdem ve 6-10 yıl kıdem öğretmenlerin e-kitap ve internetten okuma yapmayı tercih etmedikleri; sadece 11 yıl ve üzeri kıdem ögretmenlerin e-kitap ve internetten okuma yapmayı tercih ettikleri görülmektedir.

Türkçe öğretmenlerine "Hangi edebi türleri okumaktan hoşlanırsınız?" diye sorulmuş ve alınan cevaplar tabloda gösterilmiştir.

Tablo 3: Türkçe Öğretmenlerinin Okumaktan Hoşlandığı Edebi Türler

\begin{tabular}{|c|c|c|c|c|c|c|c|c|}
\hline \multirow{2}{*}{$\begin{array}{l}\text { Edebi } \\
\text { Türler }\end{array}$} & \multicolumn{2}{|c|}{ 1-5 Y1l Kidem } & \multicolumn{2}{|c|}{ 6-10 Y1l Kidem } & \multicolumn{2}{|c|}{$\begin{array}{l}11 \text { Yil } \\
\text { Kidem }\end{array}$} & \multicolumn{2}{|c|}{ Toplam } \\
\hline & f. & $\%$ & f. & $\%$ & f. & $\%$ & f. & $\%$ \\
\hline Roman & 22 & 28,5 & 26 & 34,2 & 84 & 30,8 & 132 & 31,1 \\
\hline Şiir & 14 & 18,1 & 8 & 10,5 & 43 & 15,8 & 65 & 15,2 \\
\hline Hikâye & 14 & 18,1 & 14 & 18,1 & 33 & 12,1 & 61 & 14,3 \\
\hline Deneme & 7 & 9 & 7 & 9,2 & 30 & 11 & 44 & 10,3 \\
\hline An1 & 7 & 9 & 4 & 5,2 & 28 & 10,2 & 39 & 9,1 \\
\hline Makale & 2 & 2,5 & 6 & 7,8 & 19 & 6,9 & 27 & 6,3 \\
\hline
\end{tabular}




\begin{tabular}{lllllllll}
\hline \hline Biyografi & 6 & 7,7 & 5 & 6,5 & 14 & 5,1 & 25 & 5,8 \\
Gezi yazısı & 3 & 3,8 & 4 & 5,2 & 12 & 4,4 & 19 & 4,4 \\
Söyleşi & 2 & 2,5 & 2 & 2,6 & 9 & 3,3 & 13 & 3,1 \\
Toplam & 77 & 100 & 76 & 100 & 272 & 100 & 425 & 100 \\
\hline
\end{tabular}

Tabloya bakıldığında Türkçe öğretmenlerinin toplamda en çok "roman" $(\% 31,1)$ edebi türünü okumayı tercih ettiği görülmektedir. Sonrasında tercih edilen edebi türler "şiir" $(\% 15,2)$, "hikâye" (14,3), "deneme" (\%10,3), "anı" (\%9,1), "makale" (\%6,3), "biyografi" (\%5,8), "gezi yazısı" $(\% 4,4)$ ve "söyleşi” $(\% 3,1)$ şeklinde sıralanmıştır.

Kıdem olarak ayrı ayrı bakıldığında, 1-5 yıl kıdemde öğretmenler yine en çok "roman $(\% 28,5)$ türünü okumayı tercih etmişlerdir. Sonrasında en çok tercih ettikleri edebi türler yine "şiir" $(\% 18,1)$ ve "hikâye" $(\% 18,1)$ dir. 1-5 y1l k1demde öğretmenlerin okumayı en az tercih ettiği edebi türler ise "makale" $(\% 2,5)$ ve "söyleşi" $(\% 2,5)$ dir. 6-10 y1l kıdemde öğretmenler en çok yine "roman" $(\% 34,2)$ edebi türünü okumayı tercih ederken en az "söyleşi”" $(\% 2,6)$ türünü okumayı tercih etmişlerdir. 11 yıl ve üzeri kıdemde öğretmenler de en çok "roman" $(\% 30,8)$ türünü okumayı tercih etmiştir. En az okumayı tercih ettikleri tür ise yine "söyleşi" $(\% 3,3)$ dir.

Türkçe öğretmenlerine "Hangi amaçlar ile okursunuz?" sorusu sorulmuş ve alınan cevaplar tabloda gösterilmiştir.

Tablo 4: Türkçe Öğretmenlerinin Okuma Amaçları

\begin{tabular}{|c|c|c|c|c|c|c|c|c|}
\hline \multirow[t]{2}{*}{ Amaçlar } & \multicolumn{2}{|c|}{ 1-5 Y1l Kidem } & \multicolumn{2}{|c|}{$\begin{array}{l}6-10 \\
\text { Kidem }\end{array}$} & \multicolumn{2}{|c|}{ Üzeri Kıdem } & \multicolumn{2}{|c|}{ Toplam } \\
\hline & f. & $\%$ & f. & $\%$ & f. & $\%$ & f. & $\%$ \\
\hline Kendimi geliştirmek için & 19 & 23,4 & 25 & 29,7 & 68 & 23 & 112 & 24,3 \\
\hline Eğlenceli vakit geçirmek için & 21 & 25,9 & 19 & 10,7 & 62 & 21 & 102 & 22,1 \\
\hline Edebi haz almak için & 15 & 18,5 & 20 & 23,8 & 63 & 21,3 & 98 & 21,3 \\
\hline Mesleki ilgilerimi sürdürmek için & 14 & 17,2 & 10 & 11,9 & 41 & 13,8 & 65 & 14,1 \\
\hline Güncel olayları takip etmek için & 6 & 7,4 & 5 & 5,9 & 38 & 12,8 & 49 & 10,6 \\
\hline Başarımı arttırmak için & 6 & 7,4 & 4 & 4,7 & 20 & 6,7 & 30 & 6,5 \\
\hline $\begin{array}{l}\text { Diğer (mutlu olmak, insanlardan } \\
\text { uzaklaşmak, ögrencilerim ile kitap } \\
\text { üzerine sohbet etmek, dünyayı ve } \\
\text { insanları anlamak için) }\end{array}$ & 0 & 0 & 1 & 1,1 & 3 & 1,1 & 4 & 0,8 \\
\hline Toplam & 81 & 100 & 84 & 100 & 295 & 100 & 460 & 100 \\
\hline
\end{tabular}

Tabloya bakıldığında, Türkçe öğretmenlerinin toplamda en çok "kendimi geliştirmek" $\% 24,3)$ amacı ile okudukları görülmektedir. Sonrasında sırası ile "eğlenceli vakit geçirmek" $(\% 22,1)$, "edebi haz almak" (\%21,3), "mesleki ilgilerimi sürdürmek" (\%14,1), "güncel olayları takip etmek" $(\% 10,6)$, "başarımı arttırmak" $(\% 6,5)$, "diğer (mutlu olmak, insanlardan uzaklaşmak, öğrencilerim ile kitap üzerine sohbet etmek, dünyayı ve insanları anlamak) $(\% 0,8)$ cevaplarını verdikleri görülmüştür.

1-5 y1l kıdemde ögretmenler, en çok "eğlenceli vakit geçirmek" $(\% 25,9)$ seçeneğini işaretlemişlerdir. En az okuma amaçları için ise "güncel olayları takip etmek" $(\% 7,4)$ ve "başarımı arttırmak" $(\% 7,4)$ seçeneklerini işaretlemişlerdir. 6-10 yıl kıdemde öğretmenler ise en çok "kendimi geliştirmek" $(\% 29,7)$ seçeneğini işaretlemişlerdir. Okuma amaçları olarak en az işaretledikleri seçenek ise "diğer" $(\% 1,1)$ seçeneğidir. 11 yıl ve üzeri kıdemde öğretmenlerin ise okuma amac1 olarak en çok "kendimi geliştirmek" (\%23) seçeneğini işaretledikleri görülmektedir. Bu kıdemde öğretmenler okuma amaçlarını belirtmek için en az "diğer" $(\% 1,1)$ seçeneğini işaretlemişlerdir.

Türkçe öğretmenlerine "Okuma seçimlerinizi neler etkiler?" sorusu sorulmuş ve alınan cevaplar aşağıdaki tabloda gösterilmiştir. 
Tablo 5: Türkçe Öğretmenlerinin Okuma Seçimlerini Etkileyen Etmenler

\begin{tabular}{|c|c|c|c|c|c|c|c|c|}
\hline \multirow{3}{*}{ Kitap Seçimini Etkileyen Etmenler } & \multirow{2}{*}{\multicolumn{2}{|c|}{$\begin{array}{l}1-5 \quad \text { Yil } \\
\text { Kidem }\end{array}$}} & \multirow{2}{*}{\multicolumn{2}{|c|}{$\begin{array}{l}\text { 6-10 } \\
\text { Kidem }\end{array}$}} & \multirow{2}{*}{\multicolumn{2}{|c|}{$\begin{array}{l}11 \quad \text { Yil ve } \\
\text { Üzeri Kidem }\end{array}$}} & \multirow{2}{*}{\multicolumn{2}{|c|}{ Toplam }} \\
\hline & & & & & & & & \\
\hline & f. & $\%$ & f. & $\%$ & f. & $\%$ & f. & $\%$ \\
\hline Yazar & 10 & 21,3 & 14 & 23,7 & 40 & 22,3 & 64 & 22,5 \\
\hline İçerik(konu) & 8 & 17 & 10 & 16,9 & 41 & 22,9 & 59 & 20,7 \\
\hline Yorum ve tavsiyeler & 7 & 14,9 & 7 & 11,9 & 18 & 10,1 & 32 & 11,2 \\
\hline Dil ve anlatım & 8 & 17 & 3 & 5,1 & 18 & 10,1 & 29 & 10,2 \\
\hline $\begin{array}{l}\text { Biçim (Kitap ismi, kapak tasarımı, } \\
\text { yayınevi, sayfa sayısı vb.) }\end{array}$ & 2 & 4,3 & 7 & 11,9 & 20 & 11,2 & 29 & 10,2 \\
\hline Tür & 1 & 2,1 & 4 & 6,8 & 15 & 8,4 & 20 & 7 \\
\hline Eğitici-öğretici niteliği & 4 & 8,5 & 4 & 6,8 & 7 & 3,9 & 15 & 5,3 \\
\hline Edebi değer & 0 & 0 & 5 & 8,5 & 7 & 3,9 & 12 & 4,2 \\
\hline İlgi alanı, merak & 7 & 14,9 & 0 & 0 & 3 & 1,7 & 10 & 3,5 \\
\hline Çok okunanlar listesi & 0 & 0 & 3 & 5,1 & 5 & 2,8 & 8 & 2,8 \\
\hline Boş & 0 & 0 & 1 & 1,7 & 3 & 1,7 & 4 & 1,4 \\
\hline Önemsediğim bir etmen yok & 0 & 0 & 1 & 1,7 & 2 & 1,1 & 3 & 1,1 \\
\hline Toplam & 47 & 100 & 59 & 100 & 179 & 100 & 285 & 100 \\
\hline
\end{tabular}

Türkçe öğretmenlerinin okuma seçimlerini etkileyen etmenlere bakıldığında toplamda; en etkili etmenin "yazar" $(\% 22,5)$ olduğu görülmüsstür. Sonrasında sırası ile "içerik(konu)" $(\% 20,7)$, yorum ve tavsiyeler (\%11,2), "dil ve anlatım" (\%10,2), "biçim" (\%10,2), "tür" (\%7), "eğitici-öğretici nitelik" $(\% 5,3)$, "edebi değer" (\%4,2), "ilgi alanı, merak" (\%3,5), "çok okunanlar listesi” $(\% 2,8)$ gibi etmenlerinin öğretmenlerin okuma seçiminde etkili olduğu görülmüştür. Öğretmenlerin toplamda $\% 1,1$ 'inin okuma seçimlerinde herhangi bir etmene dikkat etmediği, \%1,4'ünün ise soruya yanıt vermediği görülmüştür. Kıdem olarak ayrı ayrı değerlendirildiğinde de yine en etkili etmenlerin "yazar" ve "iç̧erik" olduğu görülmektedir. Aşağıda bu konuya ilişkin yer verilmiştir:

"Kişisel olarak bana getirisi olan kitapları okumaya özen gösteririm." (1-5 yll kıdem, 10.Ö)

"Özellikle herkes tarafindan okunan, iki günde biten ve hiçbir katkısı olmayan kitaplardan uzak duruyorum." (6-10 yl kıdem, 20. Ö)

"Seçeceğim kitabın bilişsel, duyuşsal ve kültürel anlamda bana katkı sağlaması önemli." (11 yıl ve üzeri kıdem, 31. Ö)

"Farklı yazarları okumayı seviyorum. Böylelikle tek bir düşünceye yönelmiyorum. Kişisel gelişim kitapları okumanın meslekte kendini geliştirmek adına önemli olduğunu düşünüyorum. Okuduğum kitabın bana bir şeyler katması gerekiyor." (11 yıl ve üzeri kıdem, 32. Ö)

"Internet sitelerinde okuyucuların eleştirilerine ve çevremdeki kişilerin tavsiyelerini dikkate alırım. Daha önce yapıtlarını okuduğum yazarların kitaplarını takip etmeye çalışırım." (11 yıl ve üzeri kıdem, 60. Ö)

Türkçe öğretmenlerine “Okuyacağınız materyalleri nasıl temin edersiniz?” sorusu sorulmuş ve cevaplar tabloda gösterilmiştir.

Tablo 6: Türkçe Öğretmenlerinin Okuma Materyallerini Temin Etme Şekilleri

\begin{tabular}{|c|c|c|c|c|c|c|c|c|}
\hline \multirow[t]{2}{*}{ Kitap Temin Etme Yolları } & \multicolumn{2}{|c|}{$\begin{array}{l}1-5 \\
\text { Kidem }\end{array}$} & \multicolumn{2}{|c|}{$\begin{array}{l}6-10 \\
\text { K1dem }\end{array}$} & \multicolumn{2}{|c|}{$\begin{array}{l}11 \text { Yil ve Üzeri } \\
\text { Kidem }\end{array}$} & \multicolumn{2}{|c|}{ Toplam } \\
\hline & f. & $\%$ & f. & $\%$ & f. & $\%$ & f. & $\%$ \\
\hline $\begin{array}{l}\text { Satın alarak (internet, kitap evi, } \\
\text { sahaf, fuarlar vb.) }\end{array}$ & 26 & 81,3 & 30 & 75 & 64 & 58,2 & 120 & 65,9 \\
\hline Ödünç alma (aile, arkadaşlar vb.) & 3 & 9,4 & 4 & 10 & 25 & 22,7 & 32 & 17,6 \\
\hline Kütüphaneler & 3 & 9,4 & 6 & 15 & 19 & 17,3 & 28 & 15,4 \\
\hline Boş & 0 & 0 & 0 & 0 & 2 & 1,8 & 2 & 1,1 \\
\hline Toplam & 32 & 100 & 40 & 100 & 110 & 100 & 182 & 100 \\
\hline
\end{tabular}


Tabloda, Türkçe öğretmenlerinin hem toplamda hem kıdem boyutunda en çok "satın alarak" $(\% 65,9)$ okuma materyali temin ettiği görülmektedir. Öğretmenler okuyacakları materyalleri internet, kitapevleri, sahaflar ve kitap fuarlarından satın alma yolu temin etmektedirler. Ayrica "ödünç alma" $(\% 17,6)$ ve "kütüphaneler" $(\% 15,4)$ de okuma materyali temin edilen yerler arasında yer almaktadır. Öğretmenlerin bir kısmı soruyu "boş" $(\% 1,1)$ bırakarak yanıtlamamıştır.

Türkçe öğretmenlerine "Genellikle nerede okumayı tercih edersiniz?" sorusu sorulmuş ve cevaplar aşağıdaki tabloda gösterilmiştir.

Tablo 7: Türkçe Öğretmenlerinin Tercih Ettiği Okuma Ortamları

\begin{tabular}{|c|c|c|c|c|c|c|c|c|}
\hline \multirow[t]{2}{*}{ Tercih Edilen Ortamlar } & \multicolumn{2}{|c|}{$\begin{array}{l}1-5 \quad \text { Yil } \\
\text { Kidem }\end{array}$} & \multicolumn{2}{|c|}{$\begin{array}{l}\text { 6-10 Y1l } \\
\text { Kidem }\end{array}$} & \multicolumn{2}{|c|}{$\begin{array}{l}11 \quad \text { Yil ve } \\
\text { Üzeri Kidem }\end{array}$} & \multicolumn{2}{|c|}{ Toplam } \\
\hline & f. & $\%$ & f. & $\%$ & f. & $\%$ & f. & $\%$ \\
\hline Evde (yatak odası, çalışma odası, salon, balkon vb.) & 15 & 50 & 21 & 52,5 & 73 & 59,8 & 109 & 64,5 \\
\hline Sessiz sakin ortamlarda (sahil, orman, kütüphane vb.) & 3 & 10 & 11 & 27,5 & 15 & 12,3 & 29 & 17,2 \\
\hline Okulda & 3 & 10 & 0 & 0 & 21 & 17,2 & 24 & 14,2 \\
\hline Her yerde (yer seçmem) & 6 & 20 & 7 & 17,5 & 10 & 8,2 & 23 & 13,6 \\
\hline Yolculukta & 2 & 6,7 & 1 & 0,5 & 3 & 2,5 & 6 & 3,6 \\
\hline Boş & 1 & 3,3 & 0 & 0 & 0 & 0 & 1 & 0,6 \\
\hline Toplam & 30 & 100 & 40 & 100 & 122 & 100 & 169 & 100 \\
\hline
\end{tabular}

Tabloya bakıldığında hem toplamda hem de kıdem bazında Türkçe öğretmenlerinin en çok "evde" $(\% 64,5)$ okumayı tercih ettikleri görülmüştür. Öğretmenler salon, yatak odası, çalışma odası, balkon gibi evin farklı bölümlerinde okumayı tercih edebilmektedir. Ayrıca sahil, orman, kütüphane gibi "sessiz sakin ortamlar" (\%17,2) "okul" $(\% 14,2)$, "yolculuk" $(\% 3,6)$ da diğer tercih ettikleri yerler arasında yer almaktadır. Öğretmenlerin bir kısmı yer seçmediklerini "her yerde" $(\% 13,6)$ okuduklarını belirtmiştir. Bir kısmı ise soruyu yanıtlamayarak "boş" $(\% 0,6)$ bırakmıştır. almaktadır:

Aşağıda öğretmenlerin kitap okumayı tercih ettikleri ortamlara ilişkin görüşleri yer 8. $\ddot{O})$

"Dikkatimi toplayabildiğim ve firsat bulduğum her yerde kitap okuyabilirim.” (1-5 yll kıdem,

"Evde, okulda her yerde okuyabilirim. Çantamda her zaman kitap taşırım. Fırsatını bulunca da çıkarır, okurum." (11 yıl ve üzeri kıdem, 30. Ö)

Türkçe öğretmenlerine "Okuduklarınızı çevrenizle/ öğrencilerinizle paylaşır mısınız? Nasıl?" sorusu sorulmuştur. Öğretmenlerin tamamı okuduklarını çevreleri ile de öğrencileri ile de paylaştıklarını söylemişlerdir. Nasıl paylaşımda bulundukları ise aşağıdaki tabloda gösterilmiştir.

Tablo 8: Türkçe Öğretmenlerinin Okuduklarını Çevreleri/Öğrencileri ile Paylașım Yolları

\begin{tabular}{llllllllll}
\hline \multirow{2}{*}{ Nasıl Paylaşırım? } & \multicolumn{2}{l}{$\begin{array}{l}1-5 \\
\text { Kıdem }\end{array}$} & \multicolumn{2}{l}{ Y1l } & \multicolumn{2}{l}{$\begin{array}{l}\text { K-10 } \\
\text { K1dem }\end{array}$} & \multicolumn{2}{l}{$\begin{array}{l}\text { Y11 Y1l ve Üzeri } \\
\text { Kidem }\end{array}$} & \multicolumn{2}{l}{ Toplam } \\
\cline { 2 - 10 } & f. & $\%$ & f. & $\%$ & f. & $\%$ & f. & $\%$ \\
\hline Anlatırım & 0 & 0 & 6 & 20,7 & 36 & 38,7 & 42 & 29,2 \\
Tavsiye ederim & 8 & 36,4 & 11 & 37,9 & 22 & 23,7 & 41 & 28,5 \\
İşlenen konu ile bağlantı kurarım & 8 & 36,4 & 3 & 10,3 & 23 & 24,7 & 34 & 23,6 \\
Alıntı yaparım & 6 & 27,3 & 3 & 10,3 & 11 & 11,8 & 20 & 13,9 \\
Kitabı ödünç veririm & 0 & 0 & 4 & 13,8 & 0 & 0 & 4 & 2,8 \\
Sosyal medya hesabımda paylaşırım & 0 & 0 & 2 & 6,9 & 1 & 1,1 & 3 & 2,1 \\
Toplam & 22 & 100 & 29 & 100 & 93 & 100 & 144 & 100 \\
\hline
\end{tabular}

Tabloda Türkçe öğretmenlerinin okuduklarını en çok "anlatarak" $(\% 29,2)$ paylaştıkları görülmektedir. Sonra sırası ile "tavsiye etme" $(\% 28,5)$, "işlenen konu ile bağlantı kurma" $(\% 23,6)$, "alıntı yapma" $(\% 13,9)$, "kitap ödünç verme" $(\% 2,8)$ ve "sosyal medyada paylaşma" $(\% 2,1)$ gibi 
yöntemler ile çevreleri ve öğrencileri ile paylaşımda bulundukları paylaşımda bulundukları görülmüştür.

1-5 y1l kıdem öğretmenlerin en çok "tavsiye etme" $(\% 36,4)$ ve "işlenen konu ile bağlantı kurma" (\%36,4) yöntemleri ile paylaşımda bulundukları görülmüştür. 1-5 y1l k1demdeki öğretmenlerin "ödünç verme" ve "sosyal medyada paylaşma" yollarını hiç kullanmadıkları görülmüştür. 6-10 y1l k1demdeki öğretmenlerin ise en çok "tavsiye etme" $(\% 37,9)$ yöntemini kullandıkları görülmektedir. 11 yıl ve üzeri kıdemde öğretmenler en çok "anlatma" $(\% 38,7)$ yöntemini kullanmakta; "kitabı ödünç verme" yöntemini hiç kullanmamaktadır. Aşağıda bu konudaki öğretmen görüşlerine örnekler verilmiştir:

11. $\ddot{O})$

"Okuduğum kitaplarda ilginç bulduğum, beni etkileyen şeyleri anlatırım." (6-10 yıl kıdem,

"Okuduğum kitaptaki olaylar, kişiler veya mekân yaşadığımız an ile paralellik gösteriyorsa paylaşırım.” (11 yll ve üzeri kıdem, 2. Ö)

"Öğretmen arkadaşlarıma okuduğum kitapları tanıtıyorum. Aynı kitapları okuduysak birlikte değerlendirme yapıyoruz." (11 yll ve üzeri kıdem, 47. Ö))

Türkçe öğretmenlerine "Okuma kültürünüzün oluşmasında hangi etmenlerin etkili olduğunu düşünüyorsunuz?" sorusu sorulmuştur ve cevabı aşağıdaki tabloda verilmiştir.

Tablo 9: Türkçe Öğretmenlerinin Okuma Kültürlerinin Oluşmasında Etkili Olan Etmenler

\begin{tabular}{|c|c|c|c|c|c|c|c|c|}
\hline \multirow[t]{2}{*}{ Etmenler } & \multicolumn{2}{|c|}{$\begin{array}{ll}1-5 & \text { Y1l } \\
\text { Kidem }\end{array}$} & \multicolumn{2}{|c|}{$\begin{array}{l}\text { 6-10 Y1l } \\
\text { Kidem }\end{array}$} & \multicolumn{2}{|c|}{$\begin{array}{l}11 \text { Y1l ve } \\
\text { Üzeri Kıdem }\end{array}$} & \multicolumn{2}{|c|}{ Toplam } \\
\hline & f. & $\%$ & f. & $\%$ & f. & $\%$ & f. & $\%$ \\
\hline Öğretmenler & 9 & 20,5 & 12 & 26,1 & 31 & 20,8 & 52 & 21,8 \\
\hline Aile & 6 & 13,6 & 10 & 21,7 & 29 & 19,5 & 45 & 18,8 \\
\hline Arkadaşlar & 5 & 11,4 & 3 & 6,5 & 24 & 16,1 & 32 & 13,4 \\
\hline Kendini geliştirme isteği & 4 & 9,1 & 2 & 4,3 & 23 & 15,4 & 29 & 12,1 \\
\hline Meslek & 2 & 4,5 & 3 & 6,5 & 14 & 9,4 & 19 & 7,9 \\
\hline Merak, ilgi & 3 & 6,8 & 5 & 10,9 & 9 & 6 & 17 & 7,1 \\
\hline $\begin{array}{l}\text { Okul yaşantıs1 (mezun olunan okullar, } \\
\text { okullarda yapılan etkinlikler }\end{array}$ & 3 & 6,8 & 0 & 0 & 9 & 6 & 12 & 5 \\
\hline $\begin{array}{l}\text { Kitap sevgisini ve okuma alışkanlığını erken } \\
\text { yaşta kazanmış olmak }\end{array}$ & 2 & 4,5 & 5 & 10,9 & 4 & 2,7 & 11 & 4,6 \\
\hline Toplumun sosyokültürel yapıs1 & 4 & 9,1 & 0 & 0 & 1 & 0,7 & 5 & 2,1 \\
\hline $\begin{array}{l}\text { Ekonomik etmenler (gelir düzeyi, kitap } \\
\text { fiyatları vb.) }\end{array}$ & 3 & 6,8 & 0 & 0 & 1 & 0,7 & 4 & 1,7 \\
\hline Doğru kitaplarla karşılaşmış olmak & 0 & 0 & 4 & 8,7 & 0 & 0 & 4 & 1,7 \\
\hline Edebi haz alma isteği & 1 & 2,3 & 2 & 4,3 & 0 & 0 & 3 & 1,3 \\
\hline Kitle iletişim araçları & 2 & 4,5 & 0 & 0 & 0 & 0 & 2 & 0,8 \\
\hline Kütüphane kullanma alışkanlığ1 & 0 & 0 & 0 & 0 & 2 & 1,3 & 2 & 0,8 \\
\hline Boş & 0 & 0 & 0 & 0 & 2 & 1,3 & 2 & 0,8 \\
\hline Toplam & 44 & 100 & 46 & 100 & 149 & 100 & 239 & 100 \\
\hline
\end{tabular}

Tabloda da görüldüğü gibi Türkçe öğretmenlerinin okuma kültürünün oluşmasında en etkili etmenin "öğretmenleri" $(\% 21,8)$ olduğu görülmüştür. Daha sonra sıra ile "aile" $(\% 18,8)$, "arkadaşlar" (\%13,4), "kendini geliştirme isteği” (\%12,1), "meslek" $(\% 7,9)$, "merak, ilgi" (\%7,1), "okul yaşantısı" (\%5), "kitap sevgisini ve okuma alışkanlığını erken yaşta kazanmış olmak" $(\% 4,6)$, "toplumun sosyokültürel yapısı" (\%2,1), "ekonomik etmenler” (\%1,7), "doğru kitaplarla karşılaşmış 
olmak" (\%1,7), "edebi haz alma isteği” (\%1,3), "kitle iletişim araçları" (\%0,8), "kütüphane kullanma alışkanlığı" $(\% 0,8)$ gibi etmenlerin öğretmenlerin okuma kültürü edinme sürecinde etkili oldukları görülmektedir. Ayrıca bazı öğretmenler soruyu "boş" $(\% 0,8)$ bırakarak yanıtlamamıştır.

1-5 yıl kıdemdeki öğretmenlerin okuma kültürlerinin oluşmasında "doğru kitaplarla karşılaşmış olmak" ve "kütüphane kullanma alışkanlığı" etmenlerinin etkili olmadığı görülmektedir. 6-10 yıl kıdemdeki öğretmenlerde ise "okul yaşantısı", "toplumun sosyokültürel yapısı", "ekonomik etmenler", "kitle iletişim araçları" ve kütüphane kullanma alışkanlığı" etmenlerinin okuma kültürü edinmelerinde etkili olmadığı görülmüştür. 11 yıl ve üzeri kıdemdeki öğretmenlerde ise "doğru kitaplarla karşılaşmış olmak", "edebi haz alma isteği" ve "kitle iletişim" araçları etmenlerinin okuma kültürü edinme sürecinde etkili olmadığı görülmüştür.

Aşağıda bu konuda öğretmen görüşlerine yer verilmiştir:

"Küçük yaşta okumaya başlamış olmam en büyük etmen, öğretmenlerimin okuduğu kitapları bana önermesi de çok etkili olmuştur." (1-5 yll kıdem, 4. Ö)

"Farklı içerik ve üslupları merak etmem ve kelimelerin bir araya gelişindeki ahenkten duyduğum hazzın etkisi olmuştur." (1-5 yll kıdem, 8. Ö)

"Erken yaşlarda kitabı sevmek en azından kitapla tanışmak lazım. Ailede kitap okuyan birinin de olması çok etkili. Bir de çocuklara iyi kitaplar sunulmalı." (6-10 yıl kıdem, 1. Ö)

"Zamaninda edebiyat öğretmenimin özendirmeleri, ailemin desteği kitap okuma kültürümün oluşmasını sağladı. Okuyan bir çevrede yaşamak bu alışkanlığımı geliştirdi." (11 yıl ve üzeri kıdem, 43. $\ddot{O})$

"Kitabın farklı bir dünya olduğunu keşfettim. Bunun yanında çevremde okuyan insanların da olması etkili oldu." (11 yıl ve üzeri kıdem, 54. Ö)

"Babam çok okurdu, büyük bir kütüphanesi vardl. İlk onun kitaplarlyla okumaya başladım. Bu durum okuma kültürü kazanmamda en büyük etken olmuştur." (11 yıl ve üzeri kıdem, 68. Ö)

\section{Öğrencilerde Okuma Kültürü Oluşturabilmek Adına Türkçe Öğretmenleri Tarafından Yapılan Etkinlikler}

Araştırmanın bu bölümünde üçüncü alt amaca ilişkin bulgular yer almaktadır. Bir başka deyişle Türkçe öğretmenlerinin öğrencilerinde okuma kültürü oluşturabilmek için yaptıkları uygulamalar ve etkinlikler bu başlık altında ele alınmıştır. Öğretmenler sorulara çoğunlukla "kitap" materyali üzerinden cevap vermiştir. Bu nedenle tablo başlıkları bu yanıtlara göre düzenlenmiştir. Türkçe öğretmenlerine "Öğrencilerinize ne sıklıkla okuma yaptırırsınız?" sorusu sorulmuş ve cevaplar aşağıdaki tabloda gösterilmiştir.

Tablo 10: Türkçe Öğretmenlerinin Öğrencilerine Okuma Yaptırma Sıklıkları

\begin{tabular}{|c|c|c|c|c|c|c|c|c|}
\hline \multirow{2}{*}{$\begin{array}{l}\text { Türkçe } \quad \text { Öğretmenlerinin } \\
\text { Öğrencilerine Okuma Yaptırma } \\
\text { Sıklıkları }\end{array}$} & \multicolumn{2}{|c|}{$\begin{array}{l}1-5 \\
\text { Kidem }\end{array}$} & \multicolumn{2}{|c|}{$\begin{array}{l}\text { 6-10 } \\
\text { Kidem }\end{array}$} & \multicolumn{2}{|c|}{$\begin{array}{l}11 \text { Yil ve Üzeri } \\
\text { Kidem }\end{array}$} & \multicolumn{2}{|c|}{ Toplam } \\
\hline & f. & $\%$ & f. & $\%$ & f. & $\%$ & f. & $\%$ \\
\hline Haftada bir saat & 16 & 59,3 & 13 & 43,3 & 47 & 51,6 & 76 & 51,4 \\
\hline Her gün & 1 & 3,7 & 7 & 23,3 & 14 & 15,4 & 22 & 14,9 \\
\hline Haftada bir kitap & 5 & 18,5 & 2 & 6,7 & 11 & 12,1 & 18 & 12,2 \\
\hline Ayda bir kitap & 2 & 7,4 & 2 & 6,7 & 10 & 11 & 14 & 9,5 \\
\hline Ayda iki kitap & 3 & 11,1 & 3 & 10 & 5 & 5,5 & 11 & 7,4 \\
\hline Seviyeye göre değişir & 0 & 0 & 3 & 10 & 2 & 2,2 & 5 & 3,4 \\
\hline Karışmam, serbest bırakırım & 0 & 0 & 0 & 0 & 2 & 2,2 & 2 & 1,4 \\
\hline Toplam & 27 & 100 & 30 & 100 & 91 & 100 & 148 & 100 \\
\hline
\end{tabular}

Tabloya toplam olarak ve kıdem bazında bakıldığında öğretmenlerin öğrencilerine en çok "haftada bir saat" $(\% 51,4)$ okuma yaptırdığı görülmektedir. Daha sonra sırası ile "her gün" $(\% 14,9)$, 
"haftada bir kitap" (\%12,2), "ayda bir kitap" (\%9,5), "ayda iki kitap" $(\% 7,4)$ seklinde okuma yaptırma sıklıkları devam etmektedir. Öğretmenlerin bir kısmı $(\% 3,4)$ kesin bir süre belirlemediklerini, okuma yaptırma sıklığının öğrencinin "seviyesine göre” değişebileceğini belirtmişlerdir. 1-5 yıl kıdemde, öğretmenlerin okuma yaptırma sıklıklarını belirlerken öğrencilerin seviyelerini dikkate almadıkları görülmektedir. Ayrıca sadece 11 yıl ve üzeri kıdemdeki öğretmenlerin öğrencilere okuma konuda "karışmam, serbest bırakırım" (\%2,2) dedikleri görülmektedir. 1-5 ve 6-10 yıl kıdemdeki öğretmenlerin öğrencilerinin okuma sıklıklarına müdahalede bulundukları görülmektedir. Öğretmenlerin bu konudaki görüşleri şöyledir:

"Kitap okuma saatimiz var. Haftada bir gün sinıfta birlikte okuyoruz. Sonra ögrenciler evde okumaya devam ediyorlar." (11 yıl ve üzeri kıdem, 69. Ö)

Türkçe öğretmenlerine “Öğrencilerinize okutacağınız kitapları nasıl belirlersiniz?” sorusu sorulmuş ve cevaplar aşağıdaki tabloda gösterilmiştir.

Tablo 11: Türkçe Öğretmenlerinin Okutacakları Kitapları Belirlemede Dikkat Ettikleri Etmenler

\begin{tabular}{|c|c|c|c|c|c|c|c|c|}
\hline \multirow{2}{*}{$\begin{array}{l}\text { Kitap Seçimlerini } \\
\text { Etmenler }\end{array}$} & \multicolumn{2}{|c|}{ 1-5 Yil Kidem } & \multicolumn{2}{|c|}{$\begin{array}{l}6-10 \\
\text { Kidem }\end{array}$} & \multicolumn{2}{|c|}{$\begin{array}{l}11 \text { Yil ve Üzeri } \\
\text { Kidem }\end{array}$} & \multicolumn{2}{|c|}{ Toplam } \\
\hline & f. & $\%$ & f. & $\%$ & f. & $\%$ & f. & $\%$ \\
\hline $\begin{array}{l}\text { Seviye (yaş, sınıf, } \\
\text { psikososyal gelişim vb.) }\end{array}$ & 15 & 34,1 & 11 & 26,8 & 34 & 24,8 & 60 & 27 \\
\hline Öğrencinin ilgi alanı & 6 & 13,6 & 7 & 17,1 & 28 & 20,4 & 41 & 18,5 \\
\hline Yorum ve tavsiyeler & 7 & 15,9 & 7 & 17,1 & 17 & 12,4 & 31 & 14 \\
\hline 100 temel eser & 5 & 11,4 & 3 & 7,3 & 12 & 8,8 & 20 & 9 \\
\hline Karışmam, serbest bırakırım & 1 & 2,3 & 2 & 4,9 & 16 & 11,7 & 19 & 8,6 \\
\hline İçerik (konu) & 3 & 6,8 & 5 & 12,2 & 8 & 5,8 & 16 & 7,2 \\
\hline Klasikler & 3 & 6,8 & 1 & 2,4 & 7 & 5,1 & 11 & 5 \\
\hline Eğitici, öğretici nitelik & 3 & 6,8 & 2 & 4,9 & 4 & 2,9 & 9 & 4,1 \\
\hline Dil ve anlatım & 1 & 2,3 & 0 & 0 & 2 & 1,5 & 3 & 1,4 \\
\hline $\begin{array}{l}\text { Biçim (kitap ismi, yayınevi, sayfa } \\
\text { savısı, kapak tasarımı vb.) }\end{array}$ & & & & & & & & \\
\hline $\begin{array}{l}\text { sayısı, kapak tasarımı vb.) } \\
\text { Tür }\end{array}$ & $\begin{array}{l}0 \\
0\end{array}$ & $\begin{array}{l}0 \\
0\end{array}$ & $\begin{array}{l}0 \\
0\end{array}$ & $\begin{array}{l}0 \\
0\end{array}$ & $\begin{array}{l}3 \\
3\end{array}$ & $\begin{array}{l}2,2 \\
2,2\end{array}$ & $\begin{array}{l}3 \\
3\end{array}$ & $\begin{array}{l}1,4 \\
1,4\end{array}$ \\
\hline Güncellik & 0 & 0 & 2 & 4,9 & 0 & 0 & 2 & 0,9 \\
\hline Yazar & 0 & 0 & 1 & 2,4 & 1 & 0,7 & 2 & 0,9 \\
\hline Ders kitabındaki temalar & 0 & 0 & 0 & 0 & 2 & 1,5 & 2 & 0,9 \\
\hline Toplam & 44 & 100 & 41 & 100 & 137 & 100 & 222 & 100 \\
\hline
\end{tabular}

Tabloya bakıldığında hem toplamda ve hem kıdem boyutunda öğretmenlerin okutacakları kitapları belirlerken en çok öğrencilerin "seviyelerini” (\%27) dikkate aldıkları görülmüştür. Kitapları öğrencilerin yaş ve sınıf seviyelerine göre; ayrıca bilişsel ve psikososyal seviyelerine göre belirlenmektedirler. Sonrasında "öğrencilerin ilgi alanları" (\%18,5), "yorum ve tavsiyeler" (\%14), "100 temel eser" (\%9) dikkate alınarak kitap seçimi yapıldığı görülmektedir. Bazı öğretmenler öğrencilerin kitap seçimlerine karışmadıklarını $(\% 8,6)$ belirtmişlerdir. "İçerik" $(\% 7,2)$, "klasikler" (\%5), "kitabın eğitici ve öğretici niteliği" (\%4,1), "dil ve anlatım" $(\% 1,4)$, "biçim" $(\% 1,4)$, "tür" $(\% 1,4)$, "güncellik" $(\% 0,9)$, "yazar" $(\% 0,9)$, "ders kitaplarındaki temalar" $(\% 0,9)$ da Türkçe öğretmenlerinin öğrencilerine okutacakları kitapları belirlemelerinde etkili olan diğer etmenler olarak belirlenmiştir.

1-5 y1l ve 6-10 y1l kıdemdeki öğretmenlerin kitap seçiminde; kitabın ismi, yayınevi, sayfa sayısı, kapak tasarımı gibi "biçim" özelliklerine, kitabın "türüne" ve "ders kitaplarındaki temalara" dikkat etmediği görülmüştür. Ayrıca 1-5 yıl kıdeme sahip öğretmenlerin "güncellik" ve "yazar" unsurlarını da dikkate almadıkları görülmüştür. Yine 6-10 yıl kıdem öğretmenlerin "dil ve anlatım" unsuruna dikkat etmedikleri tespit edilmiştir. Öğretmenlerin bu konudaki görüşleri şöyledir: 
"Çoğunlukla 100 Temel eserden seçerim. Sosyal paylaşım sitelerinde Türkçe öğretmenliği ile ilgili sayfaları takip eder, orada önerilen kitapları alırım." (1-5 yıl kıdem, 1. Ö)

"Müfredata göre, konulara uygun, ögrrendikleri bilgileri kullanabilecekleri kitapları seçiyorum." (1-5 yll kldem, 5. Ö)

"Öğretmen arkadaşlarımla fikir alışverişi yaparak öğrenci seviyesine uygun kitapları okutmaya çalışırım." (6-10 yıl kıdem, 13. Ö)

"Onları serbest bırakıyorum. Zira bir kitabı birine okutmaya çalışmak doğru değil. Herkes beğenisi yönünde okur, okumall da.” (11 yll ve üzeri kıdem, 35. Ö)

“Öğrencilerimin kişilik özelliklerini ve bireysel farklllıklarını göz önünde bulundurarak seçerim." (11 yll ve üzeri kidem, 12. Ö)

"Okumaktan zevk alacakları, seviyelerine uygun, onlara bir şeyler kazandıracak kitapları seçerim." (11 yll ve üzeri kldem, 43. Ö)

"Öğrenciler okudukları kitapları sınıfa getirip tanıtırlar, okumaları için birbirlerini özendirirler. Kendi aralarında kitap değişimi yaparlar.” (11 yıl ve üzeri kıdem, 43. Ö)

"Farklı yazı türlerini tanımalarını isterim. Kitabın vereceği mesaja göre seçerim. Aynı zamanda okumaktan keyif almalarını da isterim." (11 yıl ve üzeri kıdem, 85. Ö)

Türkçe öğretmenlerine “Öğrencilerinizle birlikte kitap okur musunuz? Neden?” sorular1 sorulmuştur. Öğretmenlerin tamamı öğrencilerle birlikte kitap okuduklarını söylemişlerdir. Öğretmenlerin öğrencilerle birlikte okuma nedenleri aşağıdaki tabloda gösterilmiştir.

Tablo 12: Türkçe Öğretmenlerinin Öğrencileri ile Birlikte Kitap Okuma Nedenleri

\begin{tabular}{|c|c|c|c|c|c|c|c|c|}
\hline \multirow{3}{*}{ Nedenler } & $1-5$ & Y1l & $6-1$ & Y11 & 11 & 11 ve & Topl & \\
\hline & \multicolumn{2}{|c|}{ Kidem } & \multicolumn{2}{|c|}{ Kidem } & \multicolumn{4}{|c|}{ Üzeri K1dem } \\
\hline & f. & $\%$ & f. & $\%$ & f. & $\%$ & f. & $\%$ \\
\hline Rol model olmak için & 14 & 60,9 & 14 & 51,9 & 47 & 52,2 & 75 & 53,6 \\
\hline Boş & 3 & 13 & 6 & 22,2 & 28 & 31,1 & 37 & 26,4 \\
\hline Okuma saati var & 2 & 8,7 & 1 & 3,7 & 7 & 7,8 & 10 & 7,1 \\
\hline Okumaya teşvik eder & 0 & 0 & 5 & 18,5 & 4 & 4,4 & 9 & 6,4 \\
\hline Öğretmen-öğrenci paylaşımı artar & 3 & 13 & 1 & 3,7 & 4 & 4,4 & 8 & 5,7 \\
\hline Okumada devamlılık sağlar & 1 & 4,3 & 0 & 0 & 0 & 0 & 1 & 0,7 \\
\hline Toplam & 23 & 100 & 27 & 100 & 90 & 100 & 140 & 100 \\
\hline
\end{tabular}

Tabloya bakıldığında toplamda ve kıdem boyutunda öğretmenlerin en çok öğrencilerine "rol model olmak için" $(\% 53,6)$ birlikte kitap okudukları görülmektedir. Öğretmenlerin bazıları sadece birlikte okuduklarını belirtmişler; ancak neden birlikte okumayı tercih ettiklerini açıklamayarak soruyu "boş" $(\% 26,4)$ bırakmışlardır. Bir kısmı okulda "okuma saati" $(\% 7,1)$ olduğu için öğrencilerle birlikte okuduğunu belirtmiştir. Ayrıca "okumaya teşvik etme" $(\% 6,4)$, "öğretmen- öğrenci paylaşımını arttırma" (\%5,7) ve "okumada devamlılı sağlama" $(\% 0,7)$ gibi nedenlerle öğretmenlerin öğrencilerle birlikte okudukları tespit edilmiştir.

1-5 yıl kıdemdeki öğretmenlerin "okumaya teşvik etme" amacı taşımadığı; 6-10 yıl ve 11 yıl ve üzeri kıdemdeki öğretmenlerin ise "okumada devamlılık sağlama" amacı taşımadıkları tespit edilmiştir.

Öğretmenlerin bu konudaki görüşleri şöyledir: kıdem, 8. O)

"Birlikte kitap okumak ve okuduklarını paylaşmak okumanın sürekliliğini sağllyor." (1-5 yll 
"Birlikte kitap okuduğumuz anlarda hem ben huzur buluyorum hem de ögrencilerim mutlu oluyorlar." (6-10 yll kıdem, 1. Ö)

“Görgülü kuş gördüğ̈̈nü işler. Yani söylemek yerine örnek olurum.” (11 yll ve üzeri kıdem,

Türkçe öğretmenlerine "Öğrencilerinize kitap okuma konusunda örnek olduğunuzu düşünüyor musunuz?" sorusu sorulmuştur. Öğretmenlerin \%99'u "evet" cevabını verirken \%1'i "hayır" cevabını vermiştir. Hayır cevabı veren öğretmenler herhangi bir neden belirtmezken evet diyen öğretmenlerin bu konuda öğrencilerine örnek olma yolları aşağıldaki tabloda gösterilmiştir.

Tablo 13: Türkçe Öğretmenlerinin Okuma Konusunda Öğrencilerine Örnek Olma Yolları

\begin{tabular}{|c|c|c|c|c|c|c|c|c|}
\hline \multirow[t]{2}{*}{ Nasıl örnek olurum? } & \multicolumn{2}{|c|}{$\begin{array}{l}1-5 \\
\text { Kidem }\end{array}$} & \multicolumn{2}{|c|}{$\begin{array}{l}\text { 6-10 } \\
\text { Kidem }\end{array}$} & \multicolumn{2}{|c|}{$\begin{array}{l}11 \text { Y1l ve } \\
\text { Üzeri K1dem }\end{array}$} & \multicolumn{2}{|c|}{ Toplam } \\
\hline & f. & $\%$ & f. & $\%$ & f. & $\%$ & f. & $\%$ \\
\hline Öğrencilerle birlikte okurum & 8 & 38,1 & 9 & 28,1 & 31 & 42,5 & 48 & 38,1 \\
\hline Kitap öneririm & 4 & 19 & 3 & 9,4 & 21 & 28,8 & 28 & 22,2 \\
\hline Yanımda her zaman kitap taşırım & 1 & 4,8 & 5 & 15,6 & 18 & 24,7 & 24 & 19 \\
\hline Öğrencilerin görebileceği yerlerde okurum & 7 & 33,3 & 8 & 25 & 0 & 0 & 15 & 11,9 \\
\hline Kitabın önemini ve faydalarını anlatırım & 0 & 0 & 5 & 15,6 & 3 & 4,1 & 8 & 6,3 \\
\hline Okumaya teşvik eden faaliyetler düzenlerim & & & & & & & & \\
\hline (okuma saati, okuma yarışması vb.) & 1 & 4,8 & 2 & 6,3 & 0 & 0 & 3 & 2,4 \\
\hline Toplam & 21 & 100 & 32 & 100 & 73 & 100 & 126 & 100 \\
\hline
\end{tabular}

Tabloya bakıldığında toplamda ve kıdem bazında öğretmenlerin kitap okuma konusunda en çok "öğrencileriyle birlikte kitap okuyarak" $(\% 38,1)$ öğrencilerine örnek oldukları görülmüştür. Bunun dışında "kitap önererek" (\%22,2), "yanlarında hep kitap taşıyarak" (\%19), "öğrencilerin görebileceği yerlerde okuyarak" (\%11,9), "kitabın önemini ve faydalarını anlatarak" (\%6,3) Türkçe öğretmenlerinin okuma konusunda öğrencilerine örnek oldukları görülmüsstür. Ayrıca okuma saati, okuma yarışması gibi "okumaya teşvik eden etkinlikler düzenleyerek" $(\% 2,4)$ de öğrencileri okumaya teşvik ettikleri görülmektedir.

1-5 yıl kıdemdeki ögretmenlerin "kitabın önemini ve faydalarını anlatmadıkları"; 11 yıl ve üzeri kıdeme sahip öğretmenlerin "öğrencilerin görebileceği yerlerde kitap okumadığı" ve "okumaya teşvik eden etkinlikler düzenlemedikleri” görülmüştür.

Öğretmenlerin bu konudaki görüşleri şöyledir:

“Okumaya teşvik eden faaliyetler düzenlerim.” (1-5 yıl kıdem, 1. Ö)

"Mümkün olduğunca kitap okumayı yüceltir ve okumamla övünürüm. Onları da okumaya teşvik edebilmek için görebilecekleri yerde okurum." (6-10 yıl kıdem, 5. Ö)

"Okuyup beğendiğim kitapları ögrencilerime önerdiğim zaman, onların da bu kitapları alıp okuduğunu ve sevdiğini gördüm.” (11 yll ve üzeri kıdem, 53. Ö)

“Öğrencilerim beni kitap okurken görürler, nöbet tutarken bile kitap okurum. Okuduğum kitaplardan sinıfta söz ederim." (11 yll ve üzeri kıdem, 85. Ö)

Türkçe öğretmenlerine "Öğrencilerinize kitap önerisinde bulunur musunuz? Neden?" soruları sorulmuştur. Öğretmenlerin \%97,1 i "evet", \%2,9 u ise "hayır" cevabını vermiştir. Öğretmenlerin evet ve hayır cevaplarını vermelerinin nedenleri aşağıdaki tablolarda gösterilmiştir. 
Tablo 14: Türkçe Öğretmenlerinin Öğrencilerine Kitap Önerisinde Bulunma Nedenleri

\begin{tabular}{|c|c|c|c|c|c|c|c|c|}
\hline \multirow[t]{2}{*}{ Evet $(\% 97,1)$ Çünkü... } & \multicolumn{2}{|c|}{$\begin{array}{l}1-5 \quad \text { Y1l } \\
\text { Kidem }\end{array}$} & \multicolumn{2}{|c|}{$\begin{array}{l}6-10 \\
\text { Kidem } \\
\end{array}$} & \multicolumn{2}{|c|}{$\begin{array}{l}11 \text { Y1l ve } \\
\text { Üzeri Kidem }\end{array}$} & \multicolumn{2}{|c|}{ Toplam } \\
\hline & f. & $\%$ & f. & $\%$ & f. & $\%$ & f. & $\%$ \\
\hline Boş & 0 & 0 & 10 & 34,5 & 43 & 50,6 & 53 & 40,2 \\
\hline $\begin{array}{l}\text { İlgi ve seviyelerine uygun kitapları } \\
\text { seçebilmeleri için }\end{array}$ & 5 & 27,8 & 9 & 31,0 & 31 & 36,5 & 45 & 34,1 \\
\hline Fikirlerimi önemsiyorlar & 5 & 27,8 & 5 & 17,2 & 6 & 7,1 & 16 & 12,1 \\
\hline Bu konuda yardım istiyorlar & 6 & 33,3 & 5 & 17,2 & 5 & 5,9 & 16 & 12,1 \\
\hline $\begin{array}{l}\text { Okumayı alıskanlık haline getirmeleri için } \\
\text { Okuma kültürü acısından cesitlilik }\end{array}$ & 1 & 5,6 & 0 & 0 & 0 & 0 & 1 & 0,8 \\
\hline kazanmaları için & 1 & 5,6 & 0 & 0 & 0 & 0 & 1 & 0,8 \\
\hline Toplam & 18 & 100 & 29 & 100 & 85 & 100 & 132 & 100 \\
\hline
\end{tabular}

Tabloya bakıldığında kitap önerisinde bulunan öğretmenlerin bir kısmı $(\% 40,2)$ neden öneride bulunduklarına ilişkin bir açıklama yapmamışlardır. Neden öneride bulunduklarına ilişkin öneride bulunan öğretmenlere bakıldığında toplamda öğretmenlerin şu cevapları verdikleri görülmüştür: "ilgi ve seviyelerine uygun kitapları seçebilmeleri için" (\%34,1), "fikirlerimi önemsiyorlar" (\%12,1), "bu konuda yardım istiyorlar" (\%12,1), "okumayı alı̧skanlık haline getirmeleri için" $(\% 0,8)$, "okuma kültürleri açısından çeşitlilik kazanmaları için” $(\% 0,8)$.

Kıdem açısından bakıldığında ise ankete katılan 1-5 y1l kıdemdeki öğretmenlerin hepsinin neden kitap önerisinde bulunduklarına ilişkin açıklamada bulundukları görülmektedir. Bu kıdemdeki öğretmenlerin kitap önerisinde bulunma nedenlerinde en çok öğrencilerin "bu konuda yardım istemeleri" (\%33,3) etkili olmaktadır. 6-10 yıl ve 11 yıl ve üzeri kıdemdeki öğretmenlerin ise kitap önerisinde bulunurken "okumayı alışkanlık haline getirmeleri için" ve "okuma kültürleri açısından çeşitlilik kazanmaları için” nedenlerini dikkate almadıkları görülmektedir.

Bu konudaki öğretmen görüşleri şöyledir:

"Bazı öğrenciler kendi okuma zevkleri oluşana kadar yönlendirilmeye ihtiyaç duyuyorlar." (11 yıl ve üzeri kldem, 11. Ö)

"Benden kitap önerisi istiyorlar." (11 yll ve üzeri kıdem, 48. Ö)

Aşağıdaki tabloda ise hayır diyen öğretmenlerin nedenleri yer almaktadır.

Tablo 15: Türkçe Öğretmenlerinin Öğrencilerine Kitap Önerisinde Bulunmama Nedenleri

\begin{tabular}{|c|c|c|c|c|c|c|c|c|c|}
\hline \multirow[t]{2}{*}{ Hayır $(\% 2,9)$ Çünkü... } & \multicolumn{3}{|c|}{$\begin{array}{ll}1-5 & \text { Y11 } \\
\text { Kidem } & \\
\end{array}$} & \multicolumn{2}{|c|}{$\begin{array}{lr}6-10 & \text { Y1l } \\
\text { Kidem } & \\
\end{array}$} & \multicolumn{2}{|c|}{$\begin{array}{l}11 \text { Yil ve Üzeri } \\
\text { Kidem }\end{array}$} & \multicolumn{2}{|c|}{ Toplam } \\
\hline & f. & $\%$ & & f. & $\%$ & f. & $\%$ & f. & $\%$ \\
\hline Kendi seçimlerini kendileri yapmalılar & 0 & 0 & & 0 & 0 & 4 & 66,6 & 4 & 66,6 \\
\hline (siyasi ve maddi açidan) & 0 & 0 & & 0 & 0 & 2 & 33,3 & 2 & 33,3 \\
\hline Toplam & 0 & 100 & & 0 & 100 & 6 & 100 & 6 & 100 \\
\hline
\end{tabular}

Türkçe öğretmenlerinin kitap önerisinde bulunmama nedenleri olarak toplamda öğrencilerin "kendi seçimlerini kendileri yapmaları" $(\% 66,6)$ düşüncesi ile siyasi ve maddi açıdan "yanlış anlaşılmalara neden olabilir" $(\% 33,3)$ düşünceleri yer almaktadır.

Kıdem boyutunda bakıldığında ise sadece 11 yıl ve üzeri kıdemdeki bazı öğretmenlerin kitap önerisinde bulunmadığı görülmektedir. Bu konudaki öğretmen görüşlerine örnekler aşağıda verilmiştir:

"Kitap önerisinde bulunmam; çünkü siyasi olarak yanlış anlaşılmaktan korkarım." (11 yll ve üzeri kıdem, 90. Ö)

"Hayır. Çünkü kendi seçimlerini kendileri yapmalılar." (11 yıl ve üzeri kıdem, 41. Ö) 
Türkçe öğretmenlerine "Önerdiğiniz kitaplarla ilgili öğrencilerinizle paylaşımda bulunur musunuz? Nasıl?" soruları sorulmuştur. Öğretmenlerin \%99 u "evet bulunurum”, \%1 i ise "hayır bulunmam" cevabını vermişlerdir. Hayır diyen öğretmenler cevapları ile ilgili bir neden belirtmemişlerdir. Evet diyen öğretmenlerin nasıl paylaşımda bulundukları ise aşağıdaki tabloda gösterilmiştir.

Tablo 16: Türkçe Öğretmenlerinin Kitaplar ile İlgili Öğrencileri ile Paylaşımda Bulunma Yolları

\begin{tabular}{|c|c|c|c|c|c|c|c|c|}
\hline \multirow[t]{2}{*}{ Nasıl Paylaşımda Bulunurum? } & \multicolumn{2}{|c|}{ 1-5 Y1l Kidem } & \multicolumn{2}{|c|}{ 6-10 Y1l Kidem } & \multicolumn{2}{|c|}{$\begin{array}{l}11 \text { Yil ve Üzeri } \\
\text { Kidem }\end{array}$} & \multicolumn{2}{|c|}{ Toplam } \\
\hline & f. & $\%$ & f. & $\%$ & f. & $\%$ & f. & $\%$ \\
\hline Kitap hakkında sohbet ederiz & 2 & 8 & 17 & 63 & 45 & 51,1 & 64 & 45,7 \\
\hline Kitap ile ilgili sorular sorarım & 13 & 52 & 6 & 22,2 & 15 & 17 & 34 & 24,3 \\
\hline Özet çıkarttırırım & 4 & 16 & 2 & 7,4 & 11 & 12,5 & 17 & 12,1 \\
\hline Boș & 3 & 12 & 0 & 0 & 10 & 11,4 & 13 & 9,3 \\
\hline Kitaptan alıntı yaparız & 0 & 0 & 2 & 7,4 & 5 & 5,7 & 7 & 5 \\
\hline Kitap tanıtımı yaptırırım & 3 & 12 & 0 & 0 & 2 & 2,3 & 5 & 3,6 \\
\hline Toplam & 25 & 100 & 27 & 100 & 88 & 100 & 140 & 100 \\
\hline
\end{tabular}

Tabloya bakıldığında toplamda Türkçe öğretmenlerinin öğrencilerine önerdikleri kitaplarla ilgili en çok "kitap hakkında sohbet ederek" $(\% 45,7)$ paylaşımda bulundukları görülmektedir. Daha sonra sırası ile; "kitap ile ilgili sorular sorarak" $(\% 24,3)$, "özet çıkarttırarak" $(\% 12,1)$, "kitaptan alıntı yaparak $(\% 5)$ ve "kitap tanıtımı yaptırarak" $(\% 3,6)$ sınıf içerisinde okunan kitaplarla ilgili olarak paylaşımda bulunulduğu görülmektedir. Öğretmenlerin bir kısmı $(\% 9,3)$ ise nasıl paylaşımda bulunduklarına dair herhangi bir bilgi vermemiştir.

1-5 yıl kıdemdeki öğretmenlerin "kitaptan alıntı" yapmadıkları tespit edilirken 6- 10 yıl kıdemdeki öğretmenlerin ise "kitap tanıtımı" yaptırmadıkları görülmüştür.

Bu konudaki öğretmen görüşleri şöyledir:

"Kitapta beğendiği ve beğenmediği bölümleri sorarım. Beğenmediği bölümleri yazarın yerinde olsa nasıl yazard, kitapta hangi kelimeler ve cümleler dikkatini çekti, kitabın heyecan veren bölümü hangisiydi gibi sorular sorarım." (1-5 yl kidem, 8. Ö)

"Kitap hakkında konuşuruz. Yazarın başka kitapları var mı diye bakarız. Yazarı beğendiysek diğer kitaplarını okuma listemize ekleriz.” (6-10 yll kıdem, 11. Ö)

"Sınıf içinde kitabı tartışırız. Her öğrenci kitapla ilgili eleştiri yapar." (11 yıl ve üzeri kıdem,

Türkçe öğretmenlerine "Öğrencileriniz edebi türlerden hangilerini okumaktan hoşlanır?" sorusu sorulmuş ve alınan cevaplar tabloda gösterilmiştir.

Tablo 17: Türkçe Öğretmenlerine Göre Öğrencilerinin Okumaktan Hoşlandıkları Edebi Türler

\begin{tabular}{|c|c|c|c|c|c|c|c|c|}
\hline \multirow{2}{*}{$\begin{array}{l}\text { Edebi } \\
\text { Türler }\end{array}$} & \multicolumn{2}{|c|}{ 1-5 Y1l Kidem } & \multicolumn{2}{|c|}{ 6-10 Y1l Kidem } & \multicolumn{2}{|c|}{$\begin{array}{l}11 \text { Y1l } \\
\text { Kidem }\end{array}$} & \multicolumn{2}{|c|}{ Toplam } \\
\hline & f. & $\%$ & f. & $\%$ & f. & $\%$ & f. & $\%$ \\
\hline Hikâye & 19 & 25,6 & 26 & 32,9 & 82 & 32,4 & 127 & 28,9 \\
\hline Roman & 17 & 22,9 & 17 & 21,5 & 76 & 30 & 110 & 25,1 \\
\hline Masal & 12 & 16,2 & 18 & 22,7 & 58 & 1,9 & 88 & 20,1 \\
\hline Şiir & 7 & 9,4 & 4 & 5 & 26 & 10,2 & 37 & 8,4 \\
\hline An1 & 9 & 12,1 & 6 & 7,5 & 20 & 3,8 & 35 & 7,9 \\
\hline Gezi yazısı & 6 & 8,1 & 4 & 5,1 & 14 & 5,5 & 24 & 5,4 \\
\hline Biyografi & 4 & 5,4 & 2 & 2,5 & 6 & 2,3 & 12 & 2,7 \\
\hline Deneme & 0 & 0 & 2 & 2,5 & 3 & 1,1 & 5 & 1,1 \\
\hline Makale & 0 & 0 & 0 & 0 & 0 & 0 & 0 & 0 \\
\hline Söyleşi & 0 & 0 & 0 & 0 & 0 & 0 & 0 & 0 \\
\hline Toplam & 74 & 100 & 79 & 100 & 253 & 100 & 438 & 100 \\
\hline
\end{tabular}


Tabloya göre "hikâye" $(\% 28,9)$ türünün öğrencilerin en sevdiği tür olduğu görülmektedir. Daha sonra sırası ile "roman" $(\% 25,1)$, "masal" $(\% 20,1)$, "şiir" $(\% 8,4)$, "anı" $(\% 7,9)$, "gezi yazısı" $(\% 5,4)$, "biyografi" $(\% 2,7)$, "deneme" $(\% 1,1)$ türlerini sevdikleri görülmüştür. Öğrencilerin "makale" ve "söyleşi" türlerini okumayı tercih etmedikleri tespit edilmiştir.

Türkçe öğretmenlerine "Öğrencilerinize kitap okutma amaçlarınız nelerdir?" sorusu sorulmuş ve alınan cevaplar tabloda gösterilmiştir.

Tablo 18: Türkçe Öğretmenlerinin Öğrencilerine Kitap Okutma Amaçları

Amaçlar

1-5 Yil Kidem 6-10 Yil Kidem 11 Y1l ve Toplam

\begin{tabular}{|c|c|c|c|c|c|c|c|c|}
\hline & & & & & & & & \\
\hline & f. & $\%$ & f. & $\%$ & f. & $\%$ & f. & $\%$ \\
\hline Okuma sevgisi kazandırabilmek & 23 & 20,5 & 27 & 20,3 & 86 & 20 & 136 & 20,6 \\
\hline $\begin{array}{l}\text { Anlama ve anlatma becerisini } \\
\text { gelistirmek }\end{array}$ & 20 & 17,8 & 25 & 18,7 & 83 & 19,3 & 128 & 19,3 \\
\hline $\begin{array}{l}\text { Kendisini } \quad \text { geliştirmesini } \\
\text { sağlamak }\end{array}$ & 18 & 16 & 23 & 17,2 & 73 & 17 & 114 & 17,2 \\
\hline Başarısını arttırmak & 12 & 10,7 & 19 & 14,2 & 65 & 15,1 & 96 & 14,5 \\
\hline $\begin{array}{l}\text { Keyifli zaman geçirmesini } \\
\text { sağlamak }\end{array}$ & 13 & 11,6 & 20 & 15,03 & 54 & 12,6 & 87 & 13,1 \\
\hline $\begin{array}{l}\text { Edebi haz duyabilmelerini } \\
\text { sağlamak }\end{array}$ & 11 & 9,8 & 15 & 11,2 & 44 & 10,2 & 70 & 10,6 \\
\hline $\begin{array}{lll}\text { Güncel olayları } & \text { takip } \\
\text { edebilmesini sağlamak } & \end{array}$ & 2 & 1,7 & 4 & 3 & 23 & 5,3 & 29 & 4,3 \\
\hline Toplam & 112 & 100 & 133 & 100 & 428 & 100 & 660 & 100 \\
\hline
\end{tabular}

Tabloya bakıldığında Türkçe öğretmenleri en çok “okuma sevgisi kazandırabilmek” $(\% 20,6)$ amacıyla öğrencilerine kitap okutmaktadır. Daha sonra sırası ile "anlama ve anlatma becerisini geliştirmesi" (\%19,3), "kendisini geliştirmesi" (\%17,2), "başarısını arttırmak" (\%14,5), "keyifli zaman geçirmesi" (\%13,1), "edebi haz duyabilmesini sağlamak" (\%10,6), "güncel olayları takip edebilmesini sağlamak" $(\% 4,3)$ gibi amaçlar benimsedikleri görülmektedir.

Türkçe öğretmenlerine "Öğrencilerinizin okuma konusunda birbirlerini olumlu etkileyebileceği etkinlikler düzenler misiniz? Örnek verebilir misiniz?” sorusu sorulmuştur. Öğretmenlerin \%98 i "evet düzenlerim" demiştir. \%2 si ise soruyu yanıtlamayarak "boş" bırakmışlardır. Evet cevabını veren öğretmenlerin düzenledikleri etkinlikler aşağıdaki tabloda gösterilmiştir.

Tablo 19: Türkçe Öğretmenlerinin Okuma Konusunda Düzenledikleri Etkinlikler

\begin{tabular}{|c|c|c|c|c|c|c|c|c|}
\hline \multirow[t]{2}{*}{ Düzenlenen Etkinlikler } & \multicolumn{2}{|c|}{$\begin{array}{l}1-5 \\
\text { Kidem }\end{array}$} & \multicolumn{2}{|c|}{$\begin{array}{l}6-10 \\
\text { Kidem }\end{array}$} & \multicolumn{2}{|c|}{$\begin{array}{l}11 \text { Yil ve Üzeri } \\
\text { Kidem }\end{array}$} & \multicolumn{2}{|c|}{ Toplam } \\
\hline & f. & $\%$ & f. & $\%$ & f. & $\%$ & f. & $\%$ \\
\hline Kitap okuma yarışması & 4 & 26,7 & 3 & 9,4 & 2 & 24,5 & 30 & 21,3 \\
\hline $\begin{array}{l}\text { Birlikte kitap okuma saati düzenleme } \\
\text { (sinıfta kütünhanede ac1k havada }\end{array}$ & 3 & 20 & 9 & 281 & 9 & 96 & 21 & 14.9 \\
\hline Boș & 0 & 0 & 0 & 0 & 18 & 19,1 & 18 & 12,8 \\
\hline Okunan kitabı sınıfta anlattırma & 0 & 0 & 4 & 12,5 & 12 & 12,8 & 16 & 11,3 \\
\hline Kitap tanıtımı & 0 & 0 & 0 & 0 & 15 & 16 & 15 & 10,6 \\
\hline Kitap sohbetleri & 3 & 20 & 4 & 12,5 & 5 & 5,3 & 12 & 8,5 \\
\hline Birbirine kitap hediye etme & 1 & 6,7 & 0 & 0 & 9 & 9,6 & 10 & 7,1 \\
\hline $\begin{array}{l}\text { Arkadaşımın kitabını } \\
\text { etkinliği }\end{array}$ & 0 & 0 & 8 & 25 & 0 & 0 & 8 & 5,7 \\
\hline Okunan kitabı sinıfta canlandırma & 3 & 20 & 2 & 6,3 & 2 & 2,1 & 7 & 5 \\
\hline $\begin{array}{l}\text { Kitap kahramanlarını tanıtan } \\
\text { görseller hazırlama }\end{array}$ & 1 & 6,7 & 0 & 0 & 0 & 0 & 1 & 0,7 \\
\hline Kitabın devamını tahmin etme oyunu & 0 & 0 & 1 & 3,1 & 0 & 0 & 1 & 0,7 \\
\hline
\end{tabular}




\begin{tabular}{lllllllll}
\hline \hline Kitap çekilişi & 0 & 0 & 1 & 3,1 & 0 & 0 & 1 & 0,7 \\
Kitap kapağı tasarlama & 0 & 0 & 0 & 0 & 1 & 1,1 & 1 & 0,7 \\
Toplam & 15 & 100 & 32 & 100 & 94 & 100 & 141 & 100 \\
\hline
\end{tabular}

Tabloya bakıldığında öğretmenlerin etkinlik olarak toplamda en çok "kitap okuma yarışması" $(\% 21,3)$ düzenlediği görülmektedir. Bu etkinlikten sonra sırası ile yapılan etkinlikler şunlardır: sınıfta, kütüphanede, açık havada vb. yerlerde "birlikte kitap okuma saati düzenleme" $(\% 14,9)$, "okunan kitabı sinıfta anlattırma" (\%11,3), "kitap tanıtımı" (\%10,6), "kitap sohbetleri $(\% 8,5)$, "birbirine kitap hediye etme" $(\% 7,1)$, "arkadaşımın kitabını okuyorum etkinliği" $(\% 5,7)$, "okunan kitabı sınıfta canlandırma etkinliği" (\%5), "kitap kahramanlarını tanıtan görseller hazırlama" (\%0,7), "kitabın devamını tahmin etme oyunu" (\%0,7), "kitap çekilişi" (\%0,7), "kitap kapağı tasarlama" $(\% 0,7)$. Bazı öğretmenler ise soruyu cevaplamayarak boş $(\% 12,8)$ bırakmışlardır.

1-5 y1l kıdemdeki öğretmenler "okunan kitabı sınıfta anlattırma", "kitap tanıtımı", "arkadaşımın kitabını okuyorum etkinliği”," "kitabın devamını tahmin etme oyunu" ve "kitap çekilişi" gibi etkinlikleri yapmamaktadır. 6-10 yıl kıdemdeki öğretmenlerin ise "kitap tanıtımı", "birbirine kitap hediye etme", "kitap kahramanlarını tanıtan görseller hazırlama" ve "kitap kapağı tasarlama" gibi etkinlikleri yapmadıkları görülmektedir. 11 yıl ve üzeri kıdemdeki öğretmenler de "arkadaşımın kitabını okuyorum", "kitap kahramanlarını tanıtan görseller hazırlama", "kitabın devamını tahmin etme oyunu" ve "kitap çekilişi”" etkinliklerini yapmamaktadırlar. 1-5 yıl $(\% 26,7)$ ve 11 yıl ve üzeri $(\% 24,5)$ kıdemdeki öğretmenlerin en çok yaptırdığı etkinlik "kitap okuma yarışması" iken; 6-10 yıl kıdemdeki öğretmenlerin en çok yaptırdığı etkinlik "birlikte kitap okuma saati düzenleme" $(\% 28,1)$ etkinliğidir.

Aşağıda Türkçe öğretmenlerinin bu soru ile ilgili dikkat çekici görüşlerine örnekler verilmiştir:

"Okulun bahçesinde daire düzeninde otururuz ve her öğrenci okuduğu kitapla ilgili paylaşımda bulunur. Sonrasında okudukları kitapları birbirlerine hediye ederler." (1-5 yıl kıdem, 3. $\ddot{O})$

"Drama odasında öğrenciler okudukları kitapların kahramanlarının yerine kendilerini koyarak canlandirma yaparlar." (1-5 yık kıdem, 7. Ö)

"Belirlenen kitaplardan her ögrenci bir kitap aliyor. Kitapların arkasina sinıf listesi yapıştırılıyor. Dönem boyunca her ögrenci arkadaşlarından kitap alıp okuyor. Kitabın sahibi kitabını okuyan arkadaşına sorular soruyor. Dönem sonunda en çok kitap okuyan ve kitabını en çok okutan ögrenciye ödül veriliyor." (6-10 yl kıdem, 11. Ö)

“Öğrencilerim okudukları kitapları sınıfta arkadaşlarına tanıtır. Ortak olarak belirlediğimiz bir kitap okunmuşsa kitap ile ilgili sorular hazırlanır ve bilgi yarlşması yapılır." (11 yıl ve üzeri kıdem, 4. Ö)

"Her kitap için puanlama sistemimiz var. Okuyan öğrenciler kitaba 10 üzerinden puan veriyor. Böylece ögrrenci çok puan alan kitapları daha çok okumak istiyor." (11 yll ve üzeri kıdem, 56. $\ddot{O})$

Türkçe öğretmenlerine öğrencilerinde okuma kültürü oluşturabilmek amacıyla aşağıdaki tabloda verilen etkinlikleri yaptırıp yaptırmadıkları sorulmuştur. Öğretmenlerin etkinlikleri yaptırma durumları aşağıdaki tabloda gösterilmiştir. Söz konusu etkinlikleri yaptırma nedenlerine ilişkin olarak öğretmenlerin neredeyse tamamı görüş bildirmemiştir. Görüş bildiren öğretmenlerin görüşleri tablonun altında verilmiştir. 
Tablo 20: Türkçe Öğretmenlerinin Öğrencilerinde Okuma Kültürü Oluşturabilmek Amaciyla Etkinlik Yaptırma Durumları

\begin{tabular}{|c|c|c|c|c|c|c|c|c|c|c|c|c|c|c|c|c|}
\hline \multirow{3}{*}{ Etkinlikler } & \multicolumn{4}{|c|}{ 1-5 Yil Kidem } & \multicolumn{4}{|c|}{ 6-10 Yil Kidem } & \multicolumn{4}{|c|}{$\begin{array}{l}11 \text { Y1l ve Üzeri } \\
\text { Kidem }\end{array}$} & \multicolumn{4}{|c|}{ Toplam } \\
\hline & \multicolumn{2}{|c|}{ Evet } & \multicolumn{2}{|c|}{ Hayır } & \multicolumn{2}{|c|}{ Evet } & \multicolumn{2}{|c|}{ Hayır } & \multicolumn{2}{|c|}{ Evet } & \multicolumn{2}{|c|}{ Hayır } & \multicolumn{2}{|c|}{ Evet } & \multicolumn{2}{|c|}{ Hayır } \\
\hline & f. & $\%$ & $f$ & $\%$ & f. & $\%$ & $\mathrm{f}$ & $\%$ & f. & $\%$ & f. & $\%$ & f. & $\%$ & f. & $\%$ \\
\hline \multirow[t]{2}{*}{ Kitap fuarlarına götürme } & 4 & 3, & 1 & 2 & 6 & 4, & 2 & 2 & 2 & 6 , & 6 & 2 & 3 & 5, & 1 & 2 \\
\hline & & 6 & 4 & $\begin{array}{l}0, \\
3\end{array}$ & & 2 & 6 & 8 & 9 & 1 & 3 & $\begin{array}{l}5, \\
5\end{array}$ & 9 & 4 & $\begin{array}{l}0 \\
3\end{array}$ & $\begin{array}{l}5, \\
2\end{array}$ \\
\hline \multirow[t]{2}{*}{ İmza günlerine götürme } & 6 & 5 , & 1 & 2 & 9 & 6 & 2 & 2 & 3 & 6 , & 5 & 2 & 4 & 6 , & 9 & 2 \\
\hline & & 5 & 7 & $\begin{array}{l}4, \\
6\end{array}$ & & 3 & 0 & $\begin{array}{l}1, \\
5\end{array}$ & 2 & 7 & 8 & $\begin{array}{l}3, \\
5\end{array}$ & 7 & 5 & 5 & $\begin{array}{l}3, \\
2\end{array}$ \\
\hline \multirow{2}{*}{$\begin{array}{l}\text { Şair ve yazar söyleşilerine } \\
\text { götürme }\end{array}$} & 8 & 7, & 1 & 2 & 6 & 4, & 2 & 2 & 3 & 7, & 5 & 2 & 5 & 7 & 9 & 2 \\
\hline & & 3 & 5 & $\begin{array}{l}1, \\
7\end{array}$ & & 2 & 3 & $\begin{array}{l}4, \\
7\end{array}$ & 7 & 8 & 3 & $\begin{array}{l}1, \\
5\end{array}$ & 1 & & 1 & $\begin{array}{l}2, \\
2\end{array}$ \\
\hline \multirow{2}{*}{$\begin{array}{l}\text { Süreli yayın (dergi, gazete } \\
\text { vb.) takibi için teşvik etme }\end{array}$} & 1 & 1 & 1 & 1 & 1 & 1 & 1 & 1 & 7 & 1 & 1 & 7 & 9 & 1 & 4 & 1 \\
\hline & 2 & $\begin{array}{l}0, \\
9\end{array}$ & 1 & $\begin{array}{l}5 \\
9\end{array}$ & 5 & $\begin{array}{l}0, \\
6\end{array}$ & 4 & $\begin{array}{l}5, \\
1\end{array}$ & 1 & $\begin{array}{l}4, \\
9\end{array}$ & 9 & 7 & 8 & $\begin{array}{l}3, \\
5\end{array}$ & 4 & $\begin{array}{l}0, \\
8\end{array}$ \\
\hline \multirow{2}{*}{$\begin{array}{l}\text { Kitap okuma ile ilgili proje } \\
\text { ödevi verme }\end{array}$} & 1 & 1 & 7 & 1 & 2 & 1 & 6 & 6 , & 7 & 1 & 1 & 5 & 1 & 1 & 2 & 6 , \\
\hline & 6 & $\begin{array}{l}4 \\
5\end{array}$ & & $\begin{array}{l}0, \\
1\end{array}$ & 3 & $\begin{array}{l}6, \\
2\end{array}$ & & 5 & 7 & $\begin{array}{l}6, \\
2\end{array}$ & 3 & 3 & $\begin{array}{l}1 \\
6\end{array}$ & 6 & 6 & 4 \\
\hline kütüphanesinden & 2 & 1 & 2 & 2 , & 2 & 1 & 2 & 2 , & 7 & 1 & 1 & 6 & 1 & 1 & 2 & 4 , \\
\hline faydalanılmasının sağlanması & 1 & $\begin{array}{l}9, \\
1\end{array}$ & & 9 & 7 & 9 & & 2 & 4 & $\begin{array}{l}5, \\
6\end{array}$ & 6 & 5 & $\begin{array}{l}2 \\
2\end{array}$ & $\begin{array}{l}6, \\
8\end{array}$ & 0 & 9 \\
\hline \multirow[t]{2}{*}{ Kitap hediye etme } & 2 & 1 & 2 & 2 , & 2 & 2 & 0 & 0 & 7 & 1 & 1 & 6 & 1 & 1 & 1 & 4 , \\
\hline & 1 & $\begin{array}{l}9, \\
1\end{array}$ & & 9 & 9 & $\begin{array}{l}0, \\
4\end{array}$ & & & 3 & $\begin{array}{l}5, \\
4\end{array}$ & 7 & 9 & $\begin{array}{l}2 \\
3\end{array}$ & $\begin{array}{l}6, \\
9\end{array}$ & 9 & 6 \\
\hline kitaplığından & 2 & 2 & 1 & 1 , & 2 & 1 & 2 & 2 , & 8 & 1 & 8 & 3 & 1 & 1 & 1 & 2 , \\
\hline faydalanılmasının sağlanması & 2 & 0 & & 4 & 7 & 9 & & 2 & 2 & $\begin{array}{l}7, \\
3\end{array}$ & & 2 & $\begin{array}{l}3 \\
1\end{array}$ & 8 & 1 & 7 \\
\hline \multirow[t]{3}{*}{ Toplam } & 1 & 1 & 6 & 1 & 1 & 1 & 9 & 1 & 4 & 1 & 2 & 1 & 7 & 1 & 4 & 1 \\
\hline & 1 & 0 & 9 & 0 & 4 & 0 & 3 & 0 & 7 & 0 & 4 & 0 & 2 & 0 & 0 & 0 \\
\hline & 0 & 0 & & 0 & 2 & 0 & & 0 & 5 & 0 & 7 & 0 & 7 & 0 & 9 & 0 \\
\hline
\end{tabular}

Tabloya bakıldığında "kitap fuarlarına götürme" etkinliğine 1-5 yıl kıdemdeki öğretmenlerin \%3,6's1 "evet götürürüm", \%20,3'ü ise "hayır götürmem" demiştir. 6-10 y1l k1demdeki öğretmenlerin \%4,2'si “evet", \%28'i ise "hayır" demiştir. 11 yıl ve üzeri kıdemdeki öğretmenler ise $\% 6,1$ "evet", \%25,5 oranında "hayır" demiştir. Toplamda öğretmenlerin \%5,4'ü "evet götürürüm", \%25,2'si "hayır götürmem" demiştir. Genel olarak öğretmen görüşlerine bakıldığında öğretmenlerin "evet” deme nedenleri: "öğrencilerin fuar atmosferini solumalarının sağlanması, bir kitabı ve yazarı tanıma imkânı sağlaması, kitaba dikkat çeken bir etkinlik olması" olarak belirlenmiştir. Hayır deme nedenleri olarak ise "imkân yetersizliği (maddiyat ve ulaşım), yakın çevrede böyle etkinliklerin yapılmaması, izin almanın zor olması (aile ve MEB), öğretmenin sorumluluk almak istememesi" olarak belirlenmiştir.

"İmza günlerine götürme” etkinliğine $1-5$ y1l kıdemdeki öğretmenlerin $\% 5,5$ 'i “evet götürürüm" demiştir, \%24,6's1 "hayır götürmem" demiştir. 6-10 yıl kıdemdeki öğretmenlerin ise $\% 6,3$ 'ü evet, \%21,5'i hayır demiştir. 11 yıl ve üzeri kıdemdeki öğretmenler ise $\% 6,7$ "evet”, \%23,5 "hayır" demiştir. Toplamda öğretmenlerin \%6,5'i “evet götürürüm”, $\% 23,2$ 'si ise "hayır götürmem" demiştir. Genel olarak öğretmen görüşlerine bakıldığında öğretmenlerin evet deme nedenleri: "okumaya teşvik etmesi, edebi zevk oluşturması, öğrencilerin duygu ve düşünce dünyalarını geliştirmesi, şair ve yazarları tanımalarını sağlaması" olarak belirlenmiştir. Hayır deme nedenleri 
olarak ise "imkân yetersizliği (maddiyat ve ulaşım), yakın çevrede böyle etkinliklerin yapılmaması, izin almanın zor olması (aile ve MEB)" olarak belirlenmiştir. Öğretmenlerin bu konudaki görüşleri şöyledir:

"Bu gibi etkinlikler büyük şehirlerde düzenlendiği için öğrencileri bu gibi etkinliklere götüremiyorum." (1-5 yıl kıdem, 13. Ö)

"Okulumuz küçük bir ilçede, imkânlarımız kısıtl. Böyle etkinlikler il merkezinde gerçekleşiyor. Bu yüzden ögrrencilerimizi şair ve yazarlarla görüşürremiyoruz.” (11 yıl ve üzeri kıdem, 5. Ö)

"Şair ve yazar söyleşilerine götürme" etkinliğine 1-5 y1l k1demdeki öğretmenlerin \%7,3’ü "evet götürürüm", \%21,7'si "hayır götürmem" demiştir. 6-10 yıl kıdemdeki öğretmenlerin \%4,2'si "evet", \%24,7'si "hayır" demiştir. 11 yıl ve üzeri kıdemdeki öğretmenlerin ise \% 7,8'i "evet", \%21,5'i "hayır" demiştir. Toplama bakıldığında öğretmenlerin \%7'si "evet götürürüm”, \%22,2'si "hayır götürmem" demiştir. Genel olarak öğretmen görüşlerine bakıldığında öğretmenlerin evet deme nedenleri: "öğrencilerin genel kültürlerini arttıran bir etkinlik olması, kitaba ilgiyi arttırması, kütüphanecilik kulüp etkinliği olması, okumaya teşvik etmesi, kitaplarla ilgili birinci ağızdan bilgi sağlamas1, özgüveni arttırması" olarak belirlenmiştir. Bu konuda bir öğretmenin görüşü şöyledir:

“Evet. Çünkü şair ve yazarlarl dinlemek onlara ilham verir." (11 yıl ve üzeri kıdem, 9. Ö)

Hayır deme nedenleri olarak ise "imkân yetersizliği (maddiyat ve ulaşım), yakın çevrede böyle etkinliklerin yapılmaması, izin almanın zor olması (aile ve MEB) olarak belirlenmiştir.

"Süreli yayın (dergi, gazete vb.) takibi için teşvik etme" etkinliğine 1-5 yıl kıdemdeki öğretmenlerin \%10,9'u "evet”, \%15,9'u "hayır" demiştir. 6-10 yıl kıdemdeki öğretmenlerin \%10,6's1 "evet", \%15,1'i "hayır" demiştir. 11 yıl ve üzeri kıdemdeki öğretmenlerin ise $\% 14,9$ 'u "evet", \%7,7'si "hayır" demiştir. Toplama bakıldığında öğretmenlerin \%13,5'i "evet teşvik ederim", $\% 10,8$ 'i "hayır teşvik etmem" demiştir. Genel olarak öğretmen görüşlerine bakıldığında evet diyen öğretmenlerin süreli yayın olarak "dergi (Bilim Çocuk, TRT Çocuk, Bilge Çocuk, Minika GO, 7'den 70 'e, Türk Dili vb.) ve gazete” önerdikleri görülmektedir. Öğretmenlerin hayır deme nedenleri ise "imkân yetersizliği (ekonomik), öğrencilerin ilgisini çekmemesi, öğretmenin kendisinin uygun bir yayın bilmemesi, öğretmenin kitap okumaya daha çok önem vermesi, öğretmenin kendisinin de bir süreli yayın takip etmemesi, öğretmenin yanlış anlaşılmaktan korkması (ekonomik ve siyasi olarak)" olarak belirlenmiştir.

"Kitap okuma ile ilgili proje ödevi verme" etkinliğine 1-5 yıl kıdemdeki öğretmenlerin $\% 14,5$ 'i "evet", \%10,1'i ise "hayır" demiştir. 6-10 y1l k1demdeki öğretmenlerin \%16,2'si "evet", \%6,5'i "hayır" demiştir. 11 yıl ve üzeri kıdemdeki öğretmenlerin ise \%16,2'si "evet", \%5,3'ü "hayır" demiştir. Toplama bakıldığında öğretmenlerin \%16'sı "evet", \%6,4'ü "hayır" demiştir. Genel olarak öğretmen görüşlerine bakıldığında öğretmenlerin evet veririm deme nedenleri: "okuma becerisi açısından faydalı bir ödev olduğu düşüncesi, hiç okumayan öğrencilerin bu yolla okumasının sağlanması, okul idaresinin böyle bir ödev verilmesinin istemesi” olarak belirlenmiştir. Bu konudaki bir öğretmen görüşü şöyledir:

"Evet, veririm; çünkü en azından hiç okumayan öğrencilere bu yolla kitap okutmuş olurum." (6-10 yl kıdem, 10. Ö)

Hayır, vermem diyen öğretmenlerin nedenleri ise "okumanın ödev olması öğrenciyi olumsuz etkiler düşüncesi, ders içerisinde yeterince kitap okutulması ve böyle bir ödeve gerek görülmemesi, öğrencilerin internetten kitap özetlerini bulmaları, okumanın notla değerlendirilmesinin ve bir görev olarak görülmesinin yanlış olduğu düşüncesi” olarak belirlenmiş̧ir. Bu konudaki örnek öğretmen görüşleri şöyledir: 
"Ödev kaygısı ile okudukları kitabın değerini anlayamadıkları için vermem. Okumak kaygılı bir süreç olmamalı. Öğrenci okurken rahat olmalı ve okumanın zevkine varmall." (1-5 yll kıdem, 8. O)

"Böyle bir ödev vermem; çünkü kitap okumanın notla değerlendirilmesini doğru bulmuyorum." (6-10 yul kudem, 11. Ö)

"Okul kütüphanesinden faydalanılmasının sağlanması" etkinliğine 1-5 yıl kıdemdeki öğretmenlerin \%19,1'i “evet”, \%2,9'u "hayır" cevabını vermiştir. 6- 10 y1l kıdemdeki öğretmenlerin $\% 19$ 'u "evet", \%2,2'si "hayır" demiștir. 11 y1l ve üzeri kıdemdeki öğretmenlerin ise \%15,6's1 "evet", $\% 6,5$ 'i "hayır" demiştir. Toplama bakıldığında öğretmenlerin \%16,8'i "evet", \%4,9'u ise "hayır" cevabını vermiştir. Genel olarak öğretmen görüsslerine bakıldığında öğretmenlerin öğrencilerinin okul kütüphanesinden faydalanmalarını sağlamalarının nedenleri: "farklı kitaplarla tanışmalarını sağlamak, okuma alışkanlığı kazandırmak, okudukları kitapları takip etmek, sorumluluk bilinci geliştirmek, ulaşılması en kolay ve yakın kitap kaynağı olması, öğrencilerin evlerinde kitaplık olmaması, araştırma ve bulma hazzını yaşatmak, öğrencilerin kitap alacak maddi güçlerinin olmaması" olarak belirlenmiştir. Bu konuda bir öğretmen görüşü şöyledir:

"Zengin bir okul kütüphanemiz var. Her ögrenciye hitap edebilecek kitaplar mevcut. Bu yüzden öğrencilerimi sık sık kütüphaneye götürürüm” (11 yıl ve üzeri kıdem, 43. Ö)

"Hayır, okul kütüphanesinden faydalandırmam" diyen öğretmenlerin nedeni ise "okulda kütüphane olmaması" olarak belirlenmiştir. Türkçe öğretmenlerini öğrencilerine kütüphane kullandıramamasının nedeninin imkân yetersizliği olduğu görülmektedir.

"Kitap hediye etme" etkinliğine 1-5 yıl kıdemdeki öğretmenlerin \%19,1'i “evet”, \%2,9’u "hayır" cevabını vermiştir. 6- 10 yıl kıdemdeki öğretmenlerin \%20,4'ü "evet" demiştir. Bu kıdemdeki öğretmenlerden hayır cevabını veren öğretmen bulunmamaktadır. 11 yıl ve üzeri k1demdeki öğretmenlerin \%15,4'ü "evet", \%6,9'u ise "hayır" demiştir. Toplama bakıldığında öğretmenlerin \%16,9'u "evet kitap hediye ederim", \%4,6'sı ise "hayır kitap hediye etmem" demiştir. Öğretmenlerin görüşlerine bakıldığında kitap hediye etme nedenlerinin "kitap sevgisi aşılaması, kitabın en güzel hediye olduğu düşüncesi, okumaya teşvik etmesi, hediyeler anı oluşturur düşüncesi, öğrencilerin kendilerinin ulaşmadığı kitapların temin edilebilmesi, nitelikli kitapların okunmasının sağlanması" olduğu görülmüştür. Öğretmenlerin bu konudaki örnek görüssleri şöyledir:

"Öğretmenim de bana kitap hediye etmişti. Ben bu sayede erken yaşta kitap okumaya başladım." (1-5 yll kıdem, 4. Ö)

"Gerçekten seveceği bir kitap hediye edersek hayatı boyunca unutamayacağı bir anıya sahip olacaktır." (6-10 yll kidem, 10. Ö)

"Okumaya teşvik etmek açısından önemli olduğunu düşünüyorum. Diğer çocuklar da hediye almak için okumaya başlayabilirler." (11 yıl ve üzeri kıdem, 51. Ö)

Hayır, kitap hediye etmem diyen öğretmenlerin nedenlerinin "öğrenci okuyacağ kendisi seçebilmeli düşüncesi, kitap hediyesinin öğrenciyi mutlu etmediği düşüncesi, okulda yeterli kitap sayısının olması, bu konuda bir ödenek olmaması" olduğu görülmüştür. Bu konudaki bir öğretmen görüşü şöyledir:

"Hayır, kitap hediye etmem. Çünkü çocukları daha yaratıcı hediyeleri seviyor. Birine nasıl ekmek hediye etmiyorsak kitap da hediye etmemeliyiz. Kitap da ekmek gibi yaşamsal bir ihtiyaç olmall." (11 yll ve üzeri kıdem, 12. Ö)

"Sınıf kitaplığından faydalanılmasının sağlanması" etkinliğine 1-5 y1l kıdemdeki öğretmenlerin \%20'si “evet”, \%1,4'ü "hayır” cevabını vermiştir. 6- 10 yıl kıdemdeki öğretmenlerin \%19'u "evet", \%2,2'si ise "hayır" cevabını vermiştir. 11 yıl ve üzeri kıdemdeki öğretmenlerin 
\%17,3'ü "evet”, \%3,2'si "hayır” cevabını vermiştir. Toplama bakıldığında öğretmenlerin \%18’i "evet sınıf kitaplığından faydalanılmasını sağlarım", \%2,7'si ise "hayır sınıf kitaplığından faydalanılmasını sağlamam" demiştir. Öğretmen görüşlerine bakıldığında evet cevabını veren öğretmenlerin nedenlerinin "öğrencilerin okuduğu kitapları takip edebilmek, farklı kitaplarla tanışmalarını sağlamak, ulaşması en kolay ve yakın kitap kaynağı olması, okuma alışkanlığı kazandırmak, sorumluluk bilinci kazandırmak, evlerinde kitaplık olmaması, birbirleri ile fikir alışverişinde bulunmalarını sağlamak" olduğu görülmüştür. Bu konudaki öğretmen görüşleri şöyledir:

"Aynı kitapları (seçilmiş kitaplar) okuyup birbirleri ile fikir alışverişi yapmalarını isterim." (6-10 yll kidem, 2. Ö)

"Evlerinde okuduklarl kitapları takip edemiyorum, seviyelerine uygun olmayan kitapları da okuyabiliyorlar. Sinıf kitaplı̆̆ından okumaları takibi kolaylaştırıyor.” (11 yıl ve üzeri kıdem, 55. Ö)

Hayır, cevabını veren öğretmenlerin nedenin "sınıfta sınıf kitaplığının olmaması” olduğu görülmüştür.

Tablonun geneline bakıldı̆̆ında öğretmenlerin en çok "sınıf kitaplığından faydalanılması" $(\% 18)$ etkinliğine "evet" cevabını verdikleri görülmektedir. Sonra sırası ile "kitap hediye etme" $(\% 16,9)$, "okul kütüphanesinden faydalanılmasının sağlanması" $(\% 16,8)$, "kitap okuma ile ilgili proje ödevi verme" (\%16), "süreli yayın takibi için teşvik etme" $(\% 13,5)$, "şair ve yazar söyleşilerine götürme" (\%7), "imza günlerine götürme" $(\% 6,5)$, "kitap fuarlarına götürme" $(\% 5,4)$ etkinliklerine "evet" cevabını verdikleri görülmektedir. Yine tablo geneline bakıldığında en çok "hayır" diyerek yapmayı tercih etmediği etkinliğin "kitap fuarlarına götürme" $(\% 25,2)$ olduğu görülmektedir. Öğretmenler sonra sırası ile "imza günlerine götürme" $(\% 23,2)$, "şair ve yazar söyleşilerine götürme" $(\% 22,2)$, "süreli yayın takibi için teşvik etme" $(\% 10,8)$, "kitap okuma ile ilgili proje ödevi verme" $(\% 6,4)$, "okul kütüphanesinden faydalanılmasının sağlanması" $(\% 4,9)$, "kitap hediye etme" $(\% 4,6)$, "sınıf kitaplığından faydalanılması" (\%2,7) etkinliklerine "hayır" cevabını vermişlerdir.

\section{Öğrencilerin Okumayı Bir Kültür Haline Getirebilmeleri İçin Türkçe Öğretmenlerinden Öneriler}

Araştırmanın bu bölümünde dördüncü alt amaca ilişkin bulgular yer almaktadır. Bir başka deyişle Türkçe öğretmenlerinin öğrencilerin okuma kültürlerini geliştirmeye yönelik önerileri bu başlık altında ele alınmıştır.

Türkçe öğretmenlerine "Öğrencilerinizin okumayı içselleştirerek, bir kültür haline getirmeleri için önerileriniz nelerdir?” sorusu sorulmuş ve cevaplar aşağıdaki tabloda gösterilmiştir.

Tablo 21: Türkçe Öğretmenlerinin Öğrencilerde Okuma Kültürü Oluşturabilmek Adına Önerileri

\begin{tabular}{|c|c|c|c|c|c|c|c|c|}
\hline \multirow[t]{2}{*}{ Öneriler } & \multicolumn{2}{|c|}{$\begin{array}{l}1-5 \quad \text { Y1l } \\
\text { Kidem }\end{array}$} & \multicolumn{2}{|c|}{$\begin{array}{l}\text { 6-10 Y1 } \\
\text { Kidem }\end{array}$} & \multicolumn{2}{|c|}{$\begin{array}{ll}11 \quad \text { Y1l ve } \\
\text { Üzeri } \\
\text { Kidem }\end{array}$} & \multicolumn{2}{|c|}{ Toplam } \\
\hline & f. & $\%$ & f. & $\%$ & f. & $\%$ & f. & $\%$ \\
\hline $\begin{array}{l}\text { Öğrencilerin ilgi alanlarına ve seviyelerine } \\
\text { uygun kitaplarla buluşmaları sağlanmalı }\end{array}$ & 7 & 22,6 & 5 & 13,5 & 21 & 15,4 & 33 & 16,2 \\
\hline $\begin{array}{l}\text { Aile bireyleri (anne, baba, kardeşler vb.) örnek } \\
\text { olmalı }\end{array}$ & 6 & 19,4 & 8 & 21,6 & 18 & 13,2 & 32 & 15,7 \\
\hline Boş & 7 & 22,6 & 4 & 10,8 & 15 & 11 & 26 & 12,7 \\
\hline $\begin{array}{l}\text { Okuma üzerine etkinlikler (fuarlar, söyleşiler, } \\
\text { drama, münazara, imza günleri, kitap günleri } \\
\text { vb.) düzenlenmeli }\end{array}$ & 5 & 16,1 & 3 & 8,1 & 15 & 11 & 23 & 11,3 \\
\hline Öğretmen rol-model olmalı & 1 & 3,2 & 0 & 0 & 20 & 14,7 & 21 & 10,3 \\
\hline Okumanın faydaları anlatılmalı & 1 & 3,2 & 2 & 5,4 & 11 & 8,1 & 14 & 6,9 \\
\hline
\end{tabular}




\begin{tabular}{|c|c|c|c|c|c|c|c|c|}
\hline Okuma bir hayat biçimi haline getirilmeli & 0 & 0 & 0 & 0 & 9 & 6,6 & 9 & 4,4 \\
\hline $\begin{array}{l}\text { Okuduklarını paylaşmaları } \\
\text { (arkadaş, aile, öğretmen ile) }\end{array}$ & 1 & 3,2 & 3 & 8,1 & 3 & 2,2 & 7 & 3,4 \\
\hline Okul-aile iş birliği sağlanmalı & 3 & 9,7 & 3 & 8,1 & 0 & 0 & 6 & 2,9 \\
\hline $\begin{array}{l}\text { Okumada süreklilik sağlanmalı (hayat boyu } \\
\text { okuma, her yerde okuma, her zaman okuma } \\
\text { vb.) }\end{array}$ & 0 & 0 & 0 & 0 & 6 & 4,4 & 6 & 2,9 \\
\hline $\begin{array}{l}\text { Okumaları için zorlama yapılmamalı (ödül } \\
\text { veya ceza) }\end{array}$ & 0 & 0 & 2 & 5,4 & 3 & 2,2 & 5 & 2,5 \\
\hline $\begin{array}{l}\text { Okuma sevgisi ve alışkanlı̆̆ erken yaşta } \\
\text { kazandırılmalı }\end{array}$ & 0 & 0 & 0 & 0 & 5 & 3,7 & 5 & 2,5 \\
\hline Kitap fiyatları düşürülmeli & 0 & 0 & 1 & 2,7 & 3 & 2,2 & 4 & 2 \\
\hline Kitaplarla temas kurmaları sağlanmalı & 0 & 0 & 2 & 5,4 & 0 & 0 & 2 & 1 \\
\hline $\begin{array}{l}\text { Okuduklarını hayatlarına } \quad \text { uygulamaları } \\
\text { sağlanmalı }\end{array}$ & 0 & 0 & 1 & 2,7 & 1 & 0,7 & 2 & 1 \\
\hline $\begin{array}{l}\text { Sevdikleri yazarların başka kitapları ile de } \\
\text { tanışmaları sağlanmalı }\end{array}$ & 0 & 0 & 1 & 2,7 & 0 & 0 & 1 & 0,5 \\
\hline $\begin{array}{l}\text { Okumanın yeri ve zamanı yoktur düşüncesi } \\
\text { benimsetilmeli }\end{array}$ & 0 & 0 & 1 & 2,7 & 0 & 0 & 1 & 0,5 \\
\hline $\begin{array}{l}\text { Kitap tanıtımı ve paylaşımı konusunda sosyal } \\
\text { medyanın önemi vurgulanmalı }\end{array}$ & 0 & 0 & 1 & 2,7 & 0 & 0 & 1 & 0,5 \\
\hline $\begin{array}{l}\text { Kütüphane kullanımı bir kültür haline } \\
\text { getirilmeli }\end{array}$ & 0 & 0 & 0 & 0 & 1 & 0,7 & 1 & 0,5 \\
\hline Kitap seçiminde sınırlandırma yapılmamalı & 0 & 0 & 0 & 0 & 1 & 0,7 & 1 & 0,5 \\
\hline $\begin{array}{l}\text { Kitle iletişim araçlarının (televizyon, internet } \\
\text { vb.) kullanımına sınır getirilmeli }\end{array}$ & 0 & 0 & 0 & 0 & 1 & 0,7 & 1 & 0,5 \\
\hline Kitaplıklar ve kütüphaneler güncelleştirilmeli & 0 & 0 & 0 & 0 & 1 & 0,7 & 1 & 0,5 \\
\hline Her evde kitaplık bulunmalı & 0 & 0 & 0 & 0 & 1 & 0,7 & 1 & 0,5 \\
\hline Okumada seçici olunması sağlanmalı & 0 & 0 & 0 & 0 & 1 & 0,7 & 1 & 0,5 \\
\hline Toplam & 31 & 100 & 37 & 100 & 136 & 100 & 204 & 100 \\
\hline
\end{tabular}

Tabloya bakıldığında toplamda öğretmenlerin en çok "öğrencilerin ilgi alanlarına ve seviyelerine uygun kitaplarla buluşmaları sağlanmalı" (\%16,2) önerisinde bulundukları görülmüştür. Sonrasında sırası ile " aile bireyleri (anne, baba, kardeşler vb.) örnek olmalı" (\%15,7), "okuma üzerine etkinlikler (fuarlar, söyleşiler, drama, münazara, imza günleri, kitap günleri vb.) düzenlenmeli" (\%11,3), "öğretmen rol model olmalı" (\%10,3), "okumanın faydaları anlatılmalı" $(\% 6,9)$, "okuma bir hayat biçimi haline getirilmeli $(\% 4,4)$, "okuduklarını paylaşmaları sağlanmalı (arkadaş, aile, öğretmen ile), “ (\%3,4), "okul-aile işbirliği sağlanmalı" (\%2,9), "okumada süreklilik sağlanmalı (hayat boyu okuma, her yerde okuma, her zaman okuma vb. )" (\%2,9), "okumaları için zorlama yapılmamalı (ödül veya ceza)" (\%2,5), "okuma sevgisi ve alışkanlığı erken yaşta kazandırılmalı" (\%2,5), "kitap fiyatları düşürülmeli" (\%2), "kitaplarla temas kurmaları sağlanmalı" (\%1), "okuduklarını hayatlarına uygulamaları sağlanmalı" (\%1), " sevdikleri yazarların başka kitapları ile de tanışmaları sağlanmalı" $(\% 0,5)$, “ okumanın yeri ve zamanı yoktur düşüncesi benimsetilmeli" (\%0,5), “ kitap tanıtımı ve paylaşımı konusunda sosyal medyanın önemi vurgulanmalı" (\%0,5), "kütüphane kullanımı bir kültür haline getirilmeli" $(\% 0,5)$, "kitap seçiminde bir sınırlandırma yapılmamalı" (\%0,5), "kitle iletişim araçlarının (televizyon, internet vb.) kullanımına sınır getirilmeli" (\%0,5), "kitaplıklar ve kütüphaneler güncelleştirilmeli" $(\% 0,5)$, "her evde kitaplık bulunmalı" (\%0,5), "okumada seçici olunması sağlanmalı" (\%0,5) önerilerinde bulunulmuştur. Öğretmenlerin bir kısmı $(\% 12,7)$ ise soruyu yanıtlamayarak boş bırakmıştır.

Kıdem bazında değerlendirildiğinde ise; $1-5$ yıl kıdemdeki öğretmenler en çok "öğrencilerin ilgi alanlarına ve seviyelerine uygun kitaplarla buluşmaları sağlanmalı" $(\% 22,6)$ cevabını 
vermişlerdir. Sonrasında bu kıdemdeki öğretmenler "aile bireyleri (anne, baba, kardeşler vb.) örnek olmalı" (\%19,4), "okuma üzerine etkinlikler (fuarlar, söyleşiler, drama, münazara, imza günleri, kitap günleri vb.) düzenlenmeli" (\%16,1), "okul-aile iş birliği sağlanmalı" (\%9,7), "öğretmen rolmodel olmalı" (\%3,2), "okumanın faydaları anlatılmalı $(\% 3,2)$, "okuduklarını paylaşmaları sağlanmalı (arkadaş, aile, öğretmen ile)" (\%3,2) önerilerinde bulunmuşlardır. Öğretmenlerin bir kısmı ise soruyu yanıtlamayarak "boş" $(\% 22,6)$ bırakmıştır. 1-5 y1l kıdemdeki öğretmenlerin diğer kıdemlere göre daha az öneride bulundukları görülmektedir. Öğretmenlerin verdiği önerilere ilişkin örnekler aşağıdadır:

"Öğrenciler bu aşamada aktif rol oynamalıdırlar. Onları sadece okuyan değil aynı zamanda okutan bireyler haline getirmeliyiz, sorumluluk vermeliyiz. Çevresine okuma konusunda örnek olan bir birey olması gerektiğini vurgulamalıyız. Okuduklarını çevresi ile paylaşmasını sağlamalıyız." (15 yll kudem, 3. Ö)

"Evde okuma kültürüne sahip ebeveynler bulunması bu konuda önemli bir adımdır. Okumaya başladı̆̆ ilk ylllarda masal, fabl gibi çocuğu okumaya sevk edecek türlerle başlanmalı sonrasında hikâye, efsane gibi türlere geçilerek aşamalı ve planlı bir çalışma yapılmalıdır. Aile ve ögretmen bu sürece katılmalıdır. Aksi takdirde çocuk büyüdükçe okuma kültürü kazandırmak zorlaşacaktır." (1-5 yıl kıdem, 9. Ö)

6-10 yıl kıdemdeki öğretmenlerin ise en çok "aile bireyleri (anne, baba, kardeşler vb.) örnek olmalı" (\%21,6) önerisinde bulundukları dikkat çekmektedir. Bu kıdemde "öğrencilerin ilgi alanlarına ve seviyelerine uygun kitaplarla buluşmaları sağlanmalı" $(\% 13,5)$ önerisi ikinci sırada yer almaktadır. Bunların dışında öğretmenler "okuma üzerine etkinlikler (fuarlar, söyleşiler, drama, münazara, imza günleri, kitap günleri vb.) düzenlenmeli" $(\% 8,1)$, "okuduklarını paylaşmaları sağlanmalı (arkadaş, aile, öğretmen ile)" (\%8,1), "okul-aile işbirliği sağlanmalı" (\%8,1), "okumaları için zorlama yapılmamalı" $(\% 5,4)$, "okumanın faydaları anlatılmalı" $(\% 5,4)$, "kitaplarla temas kurmaları sağlanmalı" (\%5,4), "kitap fiyatları düşürülmeli" "okuduklarını hayatlarına uygulamaları sağlanmalı" (\%2,7), "sevdikleri yazarların başka kitapları ile de tanışmaları sağlanmalı" $(\% 2,7)$, "okumanın yeri ve zamanı yoktur düşüncesi benimsetilmeli" $(\% 2,7)$, "kitap tanıtımı ve paylaşımı konusunda sosyal medyanın önemi vurgulanmalı" $(\% 2,7)$ önerilerinde bulunmuşlardır. Bazı öğretmenlerin soruyu yanıtlamayarak "boş" $(\% 10,8)$ bıraktıkları görülmektedir. Öğretmenlerin verdiği önerilere ilişkin örnek görüşler aşağıdadır:

"Okumanın içselleştirilebilmesi için çok okumak yerine sürekli okumak gerekiyor." (6- 10 yll kldem, 21. O)

"Kitapları, onlara hiç küsmeyen, onlar her zaman dinleyen, hep yanlarında olan arkadaşları olarak görmelerini sağlamalıyız. Günde en az bir kere kitaba dokunmalarını sağlamalıyız." (6-10 yıl kidem, 24. Ö)

“Öncelikle bu isteği oluşturacak ortamlar meydana getirmeliyiz. Okumanın kültür haline gelebilmesi için önce yetişkinlerde okuma bilinci gelişstirmeliyiz. "(6-10 yll kıdem, 25. Ö) kıdem, 26. O)

“Okuma bir görev olmaktan çıkıp zevk haline dönüşürse kültür haline gelecektir." (6-10 yıl

11 y1l ve üzeri kıdemdeki öğretmenlerin cevaplarına bakıldığında ise öğretmenlerin en çok "öğrencilerin ilgi alanlarına ve seviyelerine uygun kitaplarla buluşmaları sağlanmalı" $(\% 15,4)$ önerisinde bulundukları görülmüştür. Sonrasında "öğretmen rol-model olmalı" (\%14,7), "aile bireyleri (anne, baba, kardeşler vb.) örnek olmalı" (\%13,2), "okuma üzerine etkinlikler (fuarlar, söyleşiler, drama, münazara, imza günleri, kitap günleri vb.) düzenlenmeli” (\%11), "okumanın faydaları anlatılmalı" (\%8,1), "okuma bir hayat biçimi haline getirilmeli" $(\% 6,6)$, "okumada süreklilik sağlanmalı (hayat boyu okuma, her yerde okuma, her zaman okuma vb. )" (\%4,4), "okuma sevgisi ve alışkanlığı erken yaşta kazandırılmalı" (\%3,7), "okumaları için zorlama yapılmamalı (ödül 
veya ceza)" (\%2,2), "kitap fiyatları düşürülmeli" $(\% 2,2)$, "okuduklarını hayatlarına uygulamaları sağlanmalı" (\%0,7), "kütüphane kullanımı bir kültür haline getirilmeli" $(\% 0,7)$, "kitap seçiminde sınırlandırma yapılmamalı" (\%0,7), "kitle iletişim araçlarının (televizyon, internet vb.) kullanımına sınır getirilmeli" (\%0,7), "kitaplıklar ve kütüphaneler güncelleştirilmeli" $(\% 0,7)$, "her evde kitaplık bulunmalı" $(\% 0,7)$, "okumada seçici olunması sağlanmalı" $(\% 0,7)$ önerilerinde bulunmuşlardır. Öğretmenlerin bir kısmı ise soruyu yanıtlamayarak boş (\%11) bırakmıştır. En fazla sayıda ve çeşitlilikte öneride bulunan öğretmenlerin bu kıdemde yer aldığı görülmektedir.

"Çocuklara bu konuda ailelerin örnek olması gerekir. 'Kitap oku.' demek yerine ailelerin çocuklarının önünde kitap okuması gerekir. 'Kitap size yeni ufuklar açar.' demek yerine o ufukların neler olduğunu göstermek gerekir. Bizim seçtiğimiz değil kendi seçtikleri kitapları okumalarını ve bu konuda seçici olmalarl gerektiğini öğretmek gerekir." (11 yll ve üzeri kıdem, 1. Ö)

"Okuma kültürünün edinilmesinde ailenin çok büyük bir etken olduğunu düşünüyorum. Bebeklikten itibaren kitaplarla haşır neşir olan çocuğun kitabı içselleştireceğini, okul hayatına başladığında da yaşına uygun eserlerle tanıştırılırsa okumayı bir kültür haline getireceğini düsünüyorum." (11 yıl ve üzeri kldem, 2. Ö)

"Çocuklar okuyacakları kitapları kendileri seçmelidirler. Öğretmen ögrenciye istemediği kitabı okutturmamalıdır. Zaten bir süre sonra ögrenci kendi zevkine uygun kitapları seçmeyi ögrenecek ve keyifle okuyacaktır. Birkaç kişiyle başlayan okuma serüveni tüm sinıfi etkileyecektir." (11ve üzeri yıl kıdem, 7. Ö)

"Bir insan sadece bir hayat yaşayabilir. Ancak kitaplar binlerce hayatı önümüze serebilir. Bu farkındalığı hissettirmeliyiz." (11 yll ve üzeri kıdem,12. Ö)

“Kitap okumak ödül veya ceza olmamalıdır." (11 yll ve üzeri kıdem, 15. Ö)

"Okumanın bir çalışma değil yaşam biçimi olduğu vurgulanmalı." (11 yıl ve üzeri kıdem,

"Hayatta başarılı ve özgüven sahibi bir birey olabilmelerinde okumanın yeri ve önemi anlatılmalı." (11 yll ve üzeri kıdem, 51. Ö)

"Ilgilerini çeken kitapları okumalarının içselleştirmeyi kolaylaştırdı̆̆ını düşünüyorum." (11 yll ve üzeri kıdem, 53. Ö)

"Her gün okumalılar, her şeyi okumalılar. Toplumun ancak okumayla gelişeceğini fark etmeliler." (11 yıl ve üzeri kıdem,58. Ö)

"Nasıl acıktığımızda yiyor, içiyorsak; bilgiye, okumaya da öyle ihtiyaçları olduğunu çocuklara fark ettirmeliyiz." (11 yıl ve üzeri kıdem,89. Ö)

"Her kitapta farklı dünyalara kapı açtığımızı, farklı insanları tanıdığımızı, kitap okumanın bir gezi olduğu hissi verilmeli." (11 yll ve üzeri kıdem, 86. Ö)

\section{Sonuç, Tartışma ve Öneriler}

Türkçe öğretmenlerinin okuma kültürü edindirme sürecine etkilerini araştırmak amaciyla 23’ü 1-5 yıl kıdem, 28'i 6-10 yıl kıdem, 91'i 11 yıl ve üzeri kıdem olmak üzere 142 Türkçe öğretmenine anket uygulanmıştır. Araştırmanın bu bölümünde uygulanan anketlerden elde dilen bulgulardan yola çıkılarak araştırmanın sonuçları tartışılmış ve tartışılan sonuçlara ilişkin öneriler sunulmuştur.

Sonuçlar ve tartışmalar, "Türkçe Öğretmenlerinin Okuma Kültürlerine Dair Elde Edilen Tespitlere İlişkin Sonuçlar ve Tartışmalar”, "Öğrencilerde Okuma Kültürü Oluşturabilmek Adına Türkçe Öğretmenleri Tarafından Yapılan Etkinliklere Dair Elde Edilen Tespitlere Dair Sonuçlar ve Tartışmalar" ve "Öğrencilerin Okumayı Bir Kültür Haline Getirebilmeleri İçin Türkçe 
Öğretmenlerinin Verdiği Önerilerden Elde Edilen Tespitlere İlişkin Sonuçlar ve Tartışmalar” olmak üzere üç ana başlık altında sunulmuştur.

\section{Türkçe Öğretmenlerinin Okuma Kültürlerine Dair Elde Edilen Tespitlere İlişkin Sonuçlar ve Tartışmalar}

Türkçe öğretmenlerinin okuma sıklıkları ile ilgili bulgulara bakıldığında, öğretmenlerin okuma sıklıkları olarak "her gün $(\% 42,7)$, boş zamanlarımda $(\% 18,9)$, ayda bir kitap $(\% 13,3)$, ayda iki kitap (\%7), haftada bir kitap (\%6,3)" cevaplarını verdikleri görülmüştür. Bulgulardan yola çıkılarak araştırmaya katılan öğretmenlerin genel olarak okumaya önem veren bireyler oldukları söylenebilir. Araştırmaya katılan öğretmenlerin bir kısmı (\%11,9) soruyu yanıtlamayarak boş bırakmıştır. Bu durumda bazı öğretmenlerin okumaya gereken önemi vermediği söylenebilir. Çocuk Vakfı (2006) tarafından hazırlanan Türkiye Okuma Karnesine göre; çok okuyan 1 yılda 21 ve daha fazla kitap okuyan kişi, orta düzey okuyan 1 yılda 6-20 kitap okuyan kişi, az okuyan 1 yılda 1-5 kitap okuyan kişi, okuyucu olmayan ise hiç kitap okumayan kişi olarak belirlenmiştir. Yılmaz (2009) 2 ayda 1 kitap ya da daha az okuyanı zayıf okuyucu, ayda ortalama 1 kitap okuyanı orta düzey okuyucu ve ayda 2 kitap ve daha fazla okuyanı güçlü (etkin) okuyucu olarak adlandırmaktadır.

Öğretmenlerin tercih ettiği okuma materyallerine bakıldığında bu materyallerin "kitap $(\% 74,4)$, gazete $(\% 14,4)$, dergi $(\% 7,7)$, e-kitap $(\% 2,2)$ ve diğer (internet) $(\% 1,1)$ " olduğu görülmüştür. Buna göre Türkçe öğretmenlerinin en çok tercih ettiği okuma materyalinin "kitap" olduğu tespit edilmiştir. Kıdem olarak ayrı ayrı bakıldığında da her üç kıdemde de yine okunması en çok tercih edilen materyalin "kitap" olduğu görülmüştür. 1-5 yıl kıdem ve 6-10 yıl kıdemdeki öğretmenlerin okuma materyali tercihlerinde e-kitap ve internet kullanmadıkları; sadece $11 \mathrm{y}$ ll ve üzeri kıdemdeki öğretmenlerin e-kitap ve internetten okuma yapmayı tercih ettikleri görülmüsstür. Yaş ve kıdem olarak büyük olan 11 yıl ve üzeri kıdemdeki öğretmenlerin teknolojiye dayalı internet ve e-kitap uygulamalarını yaşça ve kıdemce küçük olan öğretmenlere göre daha fazla kullanmaları dikkat çekicidir. Kültür ve Turizm Bakanlığının (2011) oluşturduğu Türkiye Okuma Kültürü Haritasına bakıldığında kitabın (\%54) en çok okunan materyal olduğu görülmektedir. Bu bağlamda Türkiye Okuma Kültürü Haritası sonuçları ile öğretmenlerin verdikleri cevaplar örtüşmektedir. Ancak Bulut'un (2011) 14 faklı ilde branş öğretmenler üzerinde yaptığı araştırmaya bakıldığında ögretmenlerin \%15,7'sinin yeterince kitap, \%8,9'unun yeterince dergi, \%42,6'sının yeterince gazete okudukları belirtilmiştir. Bulut'un sonuçları ile öğretmenlerin verdikleri cevapları örtüşmediği görülmektedir. $\mathrm{Bu}$ bağlamda ülke genelinde bireylerin okuma materyali seçimi ile Türkçe öğretmenlerinin okuma materyali seçimlerinin örtüşmekte olduğu ancak Türkçe öğretmenleri ile farklı branşlardaki öğretmenlerin okuma materyali seçimlerinde farklılıklar olduğu söylenebilir.

Türkçe öğretmenlerinin okumayı en çok tercih ettiği edebi türe ait bulgulara bakıldığında "roman $(\% 31,1)$, şiir $(\% 15,2)$, hikâye $(\% 14,3)$, deneme $(\% 10,3)$, anı $(\% 9,1)$, makale $(\% 6,3)$, biyografi $(\% 5,8)$, gezi yazısı $(\% 4,4)$ ve söyleşi $(\% 3,1)$ " olduğu görülmüştür. Buna göre Türkçe öğretmenlerinin en çok okumayı tercih ettiği edebi türün "roman" olduğu tespit edilmiştir. En çok tercih edilen türlerde romanı "şiir" ve "hikâye" takip etmektedir. Kıdem açısından bakıldığında da her üç kıdemde de yine okunması en çok tercih edilen edebi türün "roman" olduğu görülmüştür. Bu tespitlerden yola çıkılarak araştırmaya katılan öğretmenlerin nesir(düzyazı) türlerinden olayı dayalı türleri okumayı tercih ettikleri söylenebilir. Fırat ve Coşkun'un (2017) Türkçe öğretmeni adaylarının kitap okuma kültürlerine ilişkin çalışmasında, öğretmen adaylarının en çok okumayı tercih ettiği edebi türlerin "roman $(\% 68,1)$, hikâye $(\% 32,5)$, şiir $(\% 24,3)$ " olduğu görülmektedir. Her iki çalışmada da okunması en çok tercih edilen edebi türün roman olması çalışma sonuçlarını örtüştürmektedir. Ancak Fırat ve Coşkun'un çalışmalarında öğretmen adaylarının okumayı tercih ettiği edebi türler arasında ikinci sırada şiir yerine hikâyenin yer alması dikkat çekmektedir. İki çalışma birlikte değerlendirildiğinde, Türkçe öğretmenleri ile Türkçe öğretmeni adaylarının birbirine yakın tür tercihlerde bulundukları söylenebilir. 
Türkçe öğretmenlerinin okuma amaçlarına dair bulgulara bakıldığında öğretmenlerin; "kendimi geliştirmek $(\% 24,3)$, keyifli zaman geçirmek $(\% 22,1)$, edebi haz almak $(\% 21,3)$, mesleki ilgilerimi sürdürmek $(\% 14,1)$, güncel olayları takip etmek $(\% 10,6)$, başarımı arttırmak $(\% 6,5)$, diğer (mutlu olmak, insanlardan uzaklaşmak, öğrencilerim ile kitap üzerine sohbet etmek, dünyayı ve insanları anlamak) $(\% 0,8)$ " amaçları ile okudukları görülmüştür. $\mathrm{Bu}$ durumda Türkçe öğretmenlerinin en çok "kendilerini geliştirmek" amacı ile kitap okudukları söylenebilir. Yalnızca 15 yıl kıdemdeki öğretmenler en çok "keyifli zaman geçirmek" $(\% 25,9)$ amacıyla kitap okuduklarını söylemişlerdir. Bu bağlamda öğretmenlerin okuma amaçlarının kıdem durumlarına göre farklılık gösterdiği söylenebilir. Ayyıldız, Bozkurt ve Canlı'nın (2006) Türkçe öğretmeni adayları üzerinde yaptığı çalışmalarında öğrencilerin okuma amaçlarının "bir şeyler öğrenmek için $(\% 59,5)$, edebi haz almak için (\%46,2), zaman geçirmek için (\%26)" olduğu görülmektedir. Fırat'1n (2017) Türkçe öğretmeni adayları üzerinde yaptığı araştırmaya bakıldığında ise öğrencilerin neredeyse tamamı $(\% 97,5)$ kitap okumayı meslekleri için gerekli gördüklerini belirtmiş̧lerdir. Bu bağlamda Türkçe öğretmenlerinin kitap okuma amaçları ile Türkçe öğretmeni adaylarının okuma amaçlarının örtüştüğü söylenebilir. İncelenen bütün bu çalışmalarda okuma amacı olarak en çok "kendini geliştirmek, bir şeyler öğrenmek" cevaplarının verilmesi Türkçe öğretmenlerinin ve Türkçe öğretmeni adaylarının okumaya faydacı bir anlayışla yaklaştı̆̆ sonucunu gösterir. Ayrıca öğretmenlerin lisans eğitimi sonrası kendilerini geliştirme konusuna önem verdikleri de söylenebilir.

Türkçe öğretmenlerinin okuma seçimlerini etkileyen etmenlere bakıldığında; "yazar (\%22,5) içerik (konu) $(\% 20,7)$, yorum ve tavsiyeler $(\% 11,2)$, dil ve anlatım $(\% 10,2)$, biçim $(\% 10,2)$, tür $(\% 7)$, eğitici-öğretici nitelik $(\% 5,3)$, edebi değer $(\% 4,2)$, ilgi alanı, merak $(\% 3,5)$, çok okunanlar listesi $(\% 2,8)$ " gibi etmenlerin öğretmenlerin okuma seçimlerinde etkili olduğu görülmüsştür. Bu bulgulara göre "yazar" ve "içeriğin (konunun)" öğretmenlerin okuma seçimini etkilediği sonucuna ulaşılabilir. Yine Fırat ve Coşkun'un (2017) öğretmen adaylarının okuma kültürleri üzerinde yaptıkları çalışmaya bakıldığında öğretmen adaylarının okuma seçimlerini etkileyen etmenlerin "içerik (konu) $(\% 84,3)$, yazar $(\% 80,6)$, dil ve anlatım özelliği $(\% 51,2)$, kitabın adı (\%50)” olduğu görülmüştür. Ayyıldız, Bozkurt ve Canlı'nın (2006) yaptığı çalışmada ise öğretmen adaylarının çoğunluğun (\%46,7) "kitap alırken yazara dikkat ederim" ayrıca "etrafımdaki okurlar tarafından önerilen kitaplara dikkat ederim (\%57,7), çok satanları takip ederim (\%26)" cevaplarını verdikleri görülmüştür. Bütün bu çalışmalar kıyaslandığında Türkçe öğretmenleri ile Türkçe öğretmeni adaylarının okuma seçimi ile ilgili tercihlerinin yakın olduğu söylenebilir. Kültür ve Turizm Bakanlığının (2011) 26 farklı ilde uygulama yaparak hazırladığı Türkiye Okuma Kültürü Haritası sonuçlarına bakıldığında ise kitaplar rastgele seçiliyor ve düzensiz okunuyor $(\% 45,3)$. Ayrıca düzenli olarak izlenen bir yazar yok $(\% 84,2)$. Bu bağlamda Türkçe öğretmenlerinin ve öğretmen adaylarının okuma seçimi konusunda toplumun eğitimle ilgilenmeyen kesimine göre daha bilinçli hareket ettikleri söylenebilir. Öğretmenlerin okuma seçimlerini yaparken belli kriterleri dikkate almaları ve bu kriterlere göre seçimler yapmaları onların belli bir okuma kültürüne sahip olduklarını göstermektedir.

Türkçe öğretmenlerinin okuma materyallerini temin etme yollarına bakıldığında; "satın alarak (internetten, kitapevlerinden, sahaflardan ve kitap fuarlarından) $(\% 65,9)$, ödünç alarak $(\% 17,6)$ ve kütüphanelerden $(\% 15,4)$ " okudukları kitapları temin ettikleri görülmüştür. Bu durumda Türkçe öğretmenlerini en çok tercih ettiği temin yolunun "satın alma" olduğu söylenebilir. Bu tespite göre araştırmaya katılan öğretmenlerin sadece okumayı değil, okunan materyale sahip olmayı da sevdikleri söylenebilir. Furat ve Coşkun'un (2017) Türkçe öğretmen adayları üzerinde yaptıkları çalışmada öğretmen adayları okuyacakları kitapları temin etme yolu tercihlerini "kütüphaneden ödünç alarak $(\% 84,3)$, satın alarak $(\% 79,3)$, çevreden ödünç alarak $(\% 70,6)$ " olarak belirtmişlerdir. Özkaya ve Çetin'in (2014) öğretmen adaylarının okuma alışkanlıkları ve kütüphane kullanımları üzerinde yaptıkları çalışmada öğretmen adayları okuyacakları kitapları temin etme yolu tercihlerini "kütüphaneden ödünç alırım $(\% 48,2)$, satın alırım $(\% 39,8)$, arkadaştan ödünç alırım $(\% 8,4)$ " olarak belirtmişlerdir. Bu çalışmalar karşılaştırıldığında Türkçe öğretmenlerinin okuma materyallerini daha 
çok satın alma yolu ile; öğretmen adaylarının ise kütüphane kullanımı yolu ile temin ettikleri görülmektedir. Öğretmenlerin ve öğretmen adaylarının okuma materyallerini farklı yollardan temin etmelerinde ekonomik faktörler etkili olabilir. Düzenli bir geliri olan öğretmenler okuma materyallerini satın alma yolu ile temin edebilmektedir. Öğrenciler ise henüz ekonomik bağımsızlıklarını elde etmedikleri için okuyacakları kitapları kütüphaneden ücretsiz olarak almayı tercih edebilmektedir. Başka bir bakış açısı ile bakılacak olursa Türkçe öğretmenleri kütüphane kullanımına önem vermemekte ya da ulaşabilecekleri zengin bir kütüphane bulunmamaktadır. Üniversite öğrencilerinin ise zengin üniversite kütüphanelerinden faydalanabilme avantajına sahip olduğu söylenebilir.

Türkçe öğretmenlerinin okumak için tercih ettiği ortamlara bakıldığında; "ev (salon, yatak odas1, çalışma odası, balkon vb.) (\%64,5), sessiz sakin ortamlar (sahil, orman, kütüphane vb.) $(\% 17,2)$, okul $(\% 14,2)$, yolculuk $(\% 3,6)$, bir kısmı ise yer seçmediklerini her yerde $(\% 13,6)$ " okudukları görülmüsşür. Bu bulgulardan yola çıkarak Türkçe öğretmenlerinin okumayı en çok tercih ettiği ortamın "ev" olduğu söylenebilir. Tercih edilen okuma ortamları kişinin okuma kültürünü yansıtması bakımından önemlidir. Manguel'e (2002) göre kitap okumak için herkesin bir köşesi vardır. İster önce kitabı seçilip, sonra köşe bulunsun; ister önce köşe seçilip, hangi kitabın köşenin havasına uyacağına bakılsın, zaman içinde okuma, okuma eylemi için belirli bir yer isteyecektir. Bu iki eylem arasında güçlü bir ilişki vardır. Örneğin koltuklarda okunan kitaplar vardır, masada, metroda, tramvayda okunan kitaplar vardir.

Türkçe öğretmenlerinin okuduklarını öğrencileri ile paylaşma yollarına bakıldığında; "anlatma $(\% 29,2)$, tavsiye etme $(\% 28,5)$, işlenen konu ile bağlantı kurma $(\% 23,6)$, alıntı yapma $(\% 13,9)$, kitap ödünç verme $(\% 2,8)$ ve sosyal medyada paylaşma $(\% 2,1)$ " gibi yollarla paylaşımda bulundukları görülmüştür. $\mathrm{Bu}$ durumda öğretmenlerin en çok okudukları kitabı "anlatarak" öğrencileri ile paylaşımda bulundukları söylenebilir. Kıdem boyutunda ise paylaşma yollarında farklılıklar olduğu görülmüştür. 1-5 yıl ve 6-10 kıdemde en çok "tavsiye etme" yolu ile paylaşımda bulunulurken 11 y1l ve üzeri kıdemde en çok "anlatma $(\% 38,7)$ " yolu kullanılarak paylaşımda bulunulduğu görülmüştür.

Öğrencilerle birlikte okunan kitaplar hakkında; anlatım, sorgulama, değerlendirme ve çıkarımlar yapmak önemlidir. Bunun için öğrencilerle birlikte okunan kitaplar tartışılmalıdır. Bu tartışmalar öğrencinin kişisel görüş geliştirmesine ve okunanları anlamasına yardım eder (Güneş, 2017). Bu bağlamda okunan kitapların sınıfta anlatılmasının öğrencilerin okuma kültürünü geliştirmeye faydalı olacağı söylenebilir. Öğretmenin okuduğu kitabı öğrencilerine tavsiye etmesi öğretmenini rol-model alan öğrencileri olumlu yönde etkileyecek ve onların yeni kitaplarla tanışmalarını sağlayacaktır. Derste işlenen konular ile ilişkili metinlerin ya da kitapların okunmasın derslere yardımcı nitelikte faydalı olabileceği söylenebilir.

Türkçe öğretmenlerinin okuma kültürlerinin oluşmasında etkili olan etmenlere bakıldığında; “öğretmenler $(\% 21,8)$, aile $(\% 18,8)$, arkadaşlar $(\% 13,4)$, kendini geliştirme isteği $(\% 12,1)$, meslek $(\% 7,9)$, merak, ilgi $(\% 7,1)$, okul yaşantısı $(\% 5)$, kitap sevgisini ve okuma alışkanlığını erken yaşta kazanmış olmak $(\% 4,6)$, toplumun sosyokültürel yapısı $(\% 2,1)$, ekonomik etmenler $(\% 1,7)$, doğru kitaplarla karşılaşmış olmak $(\% 1,7)$, edebi haz alma isteği $(\% 1,3)$, kitle iletişim araçları $(\% 0,8)$, kütüphane kullanma alışkanlığı $(\% 0,8)$ " gibi etmenlerin etkili olduğu görülmüştür. Bu bulgulara göre Türkçe öğretmenlerinin okuma kültürlerinin oluşmasında en önemli etmenin "öğretmen" olduğu söylenebilir. Fırat ve Coşkun'un (2017) yaptıkları çalışmada öğretmen adaylarının okuma kültürünün gelişmesinde etkili olan kişiler "öğretmen (\%64,3), aile (anne-baba-kardeş) $(\% 50,1)$, arkadaş (\%43,9)" olarak tespit edilmiştir. Arı ve Demir'in (2013) çalışmasında öğretmen adayları okuma alışkanlığı edinmelerinde "kendi istekleri (\%40), arkadaş etkisi (\%22), öğretmen (\%19), aile (\%17)" etmenlerinin etkili olduğu görülmüştür. Yalman, Özkan ve Kutluca' nın (2013) eğitim fakültesi öğrencileri üzerinde okuma sevgisi aşılamada etkili olan etmenler ile ilgili çalışmasında 
öğretmen adayları; "kişinin istekli olması $(\% 58,18)$, anne-baba $(\% 19,09)$, öğretmenler $(\% 11,82)$, arkadaşlar $(\% 7,27)$ " cevaplarını vermişlerdir. Ayrıca insan hayatında okuma alışkanlığının kazandırılması gereken çağ için "okul öncesi $(\% 26,36)$, ilkokul $(\% 54,55)$, ortaokul $(\% 10,9)$, lise $(\% 4,5)$, üniversite $(\% 3,64)$ " cevaplarını vermişlerdir. Bütün bu çalışmaların sonuçlara göre okuma kültürü oluşturma sürecinde bireylerin kendilerine model aldıkları ve okuma kültürü oluşumuna erken yaş dönemlerinde başlanması gerektiği sonucuna ulaşılabilir.

\section{Öğrencilerde Okuma Kültürü Oluşturabilmek Adına Türkçe Öğretmenleri Tarafından Yapılan Etkinliklere Dair Elde Edilen Tespitlere Dair Sonuçlar ve Tartışmalar}

Türkçe öğretmenlerin öğrencilerine kitap okutma sıklıklarına bakıldığında; "haftada bir saat $(\% 51,4)$, her gün $(\% 14,9)$, haftada bir kitap $(\% 12,2)$, ayda bir kitap $(\% 9,5)$, ayda iki kitap $(\% 7,4)$ " cevaplarının alındığı görülmüştür. Öğretmenlerin bir kısmı $(\% 3,4)$ kesin bir süre belirlemediklerini, okutma sıklı̆̆ının öğrencinin "seviyesine göre değiştiğini" belirtmişlerdir. Bu bulgulara göre öğretmenlerin yarısından fazlasının en az "haftada bir saat" öğrencilerine kitap okuttukları tespit edilmiştir. $\mathrm{Bu}$ durumda öğretmenlerin okul ortamında okumaya çok zaman ayırmadıkları söylenebilir. 1-5 yıl kıdemdeki öğretmenlerin kitap okutma sıklıklarını belirlerken öğrencilerin seviyelerini dikkate almadıkları görülmüştür. Ayrıca sadece 11 yıl ve üzeri kıdemdeki öğretmenler öğrencilere bu konuda "karışmam, serbest bırakırım" $(\% 2,2)$ demektedir. Buna göre mesleki tecrübenin öğrencilere kitap okutma sıklığını etkilediği söylenebilir. 1-5 y1l kıdemdeki öğretmenlerin "öğrencilerin seviyesini dikkate almaması" ancak diğer iki kademedeki öğretmenlerin öğrenci seviyesini önemsemeleri mesleki tecrübe arttıkça öğretmenlerin bu konuda daha ilgili ve dikkatli olmalarıyla ilgili olabilir. Ayrıca sadece 11 yıl ve üzeri kıdemdeki öğretmenlerin "öğrencilere karışmam" cevabını vermiş olmaları mesleki tecrübe ve yaş arttıkça öğretmenler tarafından öğrenci profilinin daha iyi tanındığı ve öğrencilerin seçimlerine, bireysel farklılıklarına daha çok saygı gösterildiği söylenebilir.

Kültür ve Turizm Bakanlığının (2011) hazırladığı Türkiye Okuma Kültürü Haritasına göre 7-14 yaş grubu bireyler yılda ortalama 12 kitap okuyor. Can, Türkyılmaz ve Karadeniz'in (2010) ortaokul ve lise öğrencileri üzerinde yaptıkları araştırmada öğrenciler "her zaman $(\% 12,1)$, sıklıkla $(\% 23,8)$, ara sıra $(\% 45,8)$, nadiren $(\% 14,8)$, hiçbir zaman $(\% 3,2)$ " kitap okudukları cevaplarını vermişlerdir. Bu tespitlere bakılarak Türkçe öğretmenlerinin öğrencilerine kitap okutma sıklığının yetersiz olduğu söylenebilir. Öğretmenlerin kitap okutma sıklı̆̆ının yetersiz olmasının bazı nedenleri olabilir. Türkçe öğretmenlerinin ders saatleri sınırlıdır ve bu saatleri planlı kullanmaları gerekmektedir. Ayrıca öğrenciler sadece sınıfta öğretmenlerinin gözetiminde değil evde veya dışarıda da kitap okuyabilmektedir. Kurnaz ve Yıldız'ın (2015) ortaokul öğrencileri üzerinde yaptığı araştırmada, okunan kitap sayısının artmasının okuma motivasyonu da arttırdığı tespit edilmiştir. Bu nedenle Türkçe öğretmenleri öğrencilerine okutma sıklıklarını arttırmalıdır.

Türkçe öğretmenlerinin öğrencilerine okutacakları kitapların seçimini etkileyen etmenlere bakıldığında; öğrencilerin "seviyelerini (yaş ve sınıf) (\%27), ilgi alanlarını $(\% 18,5)$, yorum ve tavsiyeleri (\%14), 100 temel eseri (\%9)" dikkate alarak kitap seçimi yaptıkları görülmüştür. Bazı öğretmenler öğrencilerin kitap seçimlerine karışmadıklarını $(\% 8,6)$ görülmüştür. "içerik $(\% 7,2)$, klasikler $(\% 5)$, kitabın eğitici ve öğretici niteliği $(\% 4,1)$, dil ve anlatım $(\% 1,4)$, biçim $(\% 1,4)$, tür $(\% 1,4)$, güncellik $(\% 0,9)$, yazar $(\% 0,9)$, ders kitaplarındaki temalar $(\% 0,9)$ " da kitap seçiminde etkili olan diğer unsurlar olarak belirlenmiştir. Buna göre öğretmenlerin kitap seçiminde en çok "öğrenci seviyesini (yaş ve sınıf), ilgi alanlarını ve tavsiyeleri” dikkate aldıkları söylenebilir. Öğrencilerin okuma kültürlerinin oluşmasında seviye, ilgi alanı ve tavsiye gibi faktörlerin etkili olduğu sonucuna ulaşılabilir. Ayrıca araştırmaya katılan öğretmenlerin öğrencilerinde okuma kültürü oluşturma konusunda bilgili ve bilinçli oldukları söylenebilir.

Kültür ve Turizm Bakanlığının (2011) hazırladığı Türkiye Okuma Kültürü Haritasına bakıldığında; en çok tavsiye edilen kitapların okunduğu (\%61,5), kitap seçiminde yayınevi tercihi 
yapılmadığı $(\% 90,1)$ görülmüştür. Bu sonuçların yapılan çalışma ile örtüştüğü söylenebilir. Türkçe öğretmenlerinin de tavsiye edilen kitaplara önem verdiği ancak yayınevini önemsemedikleri görülmüştür.

Öğretmenlerin sadece \%9’unun 100 Temel Eseri önerdiği görülmektedir. Ak Başoğul (2018) çalışmasında ise Türkçe öğretmenlerinin kitap önerisi konusunda genellikle 100 Temel Eser listesini kullandığı tespit edilmiştir. Bu bağlamda iki çalışma arasındaki sonuçlar uyuşmamaktadır. Ak Başoğul'un çalışmasında konuya ilişkin öğretmen eleştirilerine göre Türk edebiyatından seçilen kitapların çocuklar tarafından sıkıcı bulunduğu ve zevk alınarak okunmadığı, anlaşı1ır ve güncel olmadığı, okuma alıșkanlığı kazandırmaya uygun olmadığı, öğretmeni kısıtladığı, çocukların düzeyinin üstünde olduğu ayrıca sadeleştirme ve çeviri sorunlarına sahip olduğu görülmüştür. Kimi öğretmenler ise MEB onaylı olduğu için kendisini koruma amaciyla sadece 100 Temel Eser listesinden kitap önerdiklerini söylemişlerdir. Bu durumda Muğla il sınırları içerisinde görev yapmakta olan Türkçe öğretmenlerinin kitap seçimi konusunda kendilerini baskı altında hissetmeden daha rahat kitap tavsiyesinde bulunabildikleri söylenebilir.

Türkçe öğretmenlerinin; "rol model olmak için $(\% 53,6)$, okuma saati $(\% 7,1)$ olduğu için, okumaya teşvik etmek için $(\% 6,4)$, öğretmen- öğrenci paylaşımını arttırma $(\% 5,7)$ ve okumada devamlılık sağlama $(\% 0,7)$ " gibi nedenlerle öğrenciler ile okudukları görülmüştür. Buna göre araştırmaya katılan birçok Türkçe öğretmenin öğrencilerine rol model olmanın öneminin farkında olduğu ve sorumluluk duygusu ile hareket ettiği sonucuna ulaşılabilir. Yılmaz'a (2009) göre de öğretmen öğrencilerine okuma kültürü konusunda iyi bir model olmalıdır. Okumayan bir öğretmenden okuyan öğrencilere sahip olması ihtimali beklenilemez. Francois'in (2011) ortaokul öğrencilerinin okuma kültürleri ile ilgili yaptığ okumasının okumayı olumlu etkilediği görülmüştür.

Araştırmaya katılan öğretmenlerin tamamı öğrencileri ile kitap okuduğunu belirtmiştir. Anacak yaklaşık dörtte birinin $(\% 26,4)$ neden öğrencileri ile kitap okuduklarına dair bir açıklama yapmaması dikkat çekicidir. Bu bağlamda araştırmaya katılan bazı öğretmenlerin öğrencilerine okuma konusunda rol model olmanın öneminin farkında olmadığı söylenebilir.

Türkçe öğretmenlerinin kitap okuma konusunda öğrencilerin örnek olma durumlarına bakıldığında; "öğrencileri ile kitap okuyarak $(\% 38,1)$, kitap önererek $(\% 22,2)$, yanlarında hep kitap taşıyarak (\%19), öğrencilerin görebileceği yerlerde okuyarak (\%11,9), kitabın önemini ve faydalarını anlatarak $(\% 6,3)$ ve okumaya teşvik eden etkinlikler düzenleyerek $(\% 2,4)$ " öğrencilerine örnek oldukları görülmüştür. Ülper'in (2011) ilköğretim ve ortaöğretim öğrencileri üzerinde yaptığı araştırmada ilköğretim öğrencilerinin "sık sık" öğretmenleri tarafından gerçekleştirilen güdüleyici etmenlerle karşılaştıkları belirtilmiştir. Öğrenciler bu konu hakkında: "öğretmenlerimi kitap okurken görürüm, öğretmenlerim okudukları çeşitli kitapları önerirler, öğretmenlerim okudukları kitapları anlatırlar, öğretmenlerim okudukları kitabı tanıtırlar, öğretmenlerim derslerde çeşitli okuma etkinlikleri yaptırır, öğretmenlerim okumaya teşvik eder, öğretmenlerim kitap okuyanları över ve kitap hediye eder." ibarelerini kullanmışlardır. Bu bağlamda her iki çalışmanın da sonuçlarının örtüştügü, öğretmenlerin öğrencilerine kitap okuma konusunda örnek olarak onları güdüledikleri söylenebilir.

1-5 yıl kıdemdeki öğretmenlerin "kitabın önemini ve faydalarını" anlatmamaları; 11 yıl ve üzeri kıdemdeki öğretmenlerin ise "öğrencilerin görebileceği yerlerde kitap okumamaları" ve "okumaya teşvik eden etkinlikler düzenlememeleri” dikkat çekicidir. 1-5 y1l kıdemdeki öğretmenlerin bu tutumu mesleki tecrübe yetersizliği olarak değerlendirilebilirken, 11 y1l ve üzeri kıdemdeki öğretmenlerin bu konudaki tutumu mesleki yorgunluk ve bıkkınlık olarak değerlendirilebilir. Bu durumda öğrencilerine okuma konusunda örnek olma konusunda en çok 6-10 y1l kıdemdeki öğretmenlerin etkili olduğu söylenebilir. 
Türkçe öğretmenlerinin neredeyse hepsi $(\% 97,1)$ öğrencilerine okuyacakları kitaplar konusunda önerilerde bulunmaktadır. Ancak kitap önerisinde bulunan öğretmenlerin büyük bir kısmı $(\% 40,2)$ neden okuma önerisinde bulunduklarına dair bir açıklama yapmamışlardır. Bu bağlamda araştırmaya katılan bazı öğretmenlerin öneride bulunurken bilinçli hareket etmediği söylenebilir. Öğretmenlerin kitap önerisinde bulunma nedenlerine bakıldığında: "ilgi ve seviyelerine uygun kitapları seçebilmeleri için $(\% 34,1)$, fikirlerimi önemsiyorlar $(\% 12,1)$, bu konuda yardım istiyorlar $(\% 12,1)$, okumayı alışkanlık haline getirmeleri için $(\% 0,8)$, okuma kültürleri açısından çeşitlilik kazanmaları için $(\% 0,8)$ " cevaplarını verdikleri görülmüştür. Bu bulgulara göre öğretmenlerin öğrencilerin kendilerine yaş ve seviye olarak uyun kitapları seçebilmeleri için öğrencilerine rehberlik yaptıkları, öğrencilerin de öğretmenlerinin bu konudaki fikirlerini önemsedikleri ve öğretmenlerinden yardım istedikleri sonucuna ulaşılmaktadır. Ak Başoğul'un (2018) Türkçe öğretmenlerinin ve önerdikleri kitapların okuma kültürü üzerindeki etkisini araştırdığı çalışmasında Türkçe öğretmenlerinin öğrencilerine önerdiği kitaplarla öğrencilerine saygılı, zararsız, uzlaşmacı, faydalı, kültürlü, çalışkan, sorgulayan, gelişime açık, dürüst, duyarlı, sevgi dolu, mutlu, kendisine yetebilen, sorumluluk sahibi, empati kuran, iyi niyetli, değerlerine sahip çıkan ve özgüven sahibi insan tipi yetiştirmeyi amaçladıkları ve amaç doğrultusunda kitaplar önerdikleri görülmüştür. $\mathrm{Bu}$ bağlamda Türkçe öğretmenlerinin kitap önerisinde bulunurken öğrencilerine birtakım değerleri de kazandırmayı amaçlamaları gerekmektedir.

Araştırmaya katılan 1-5 y1l kıdemdeki öğretmenlerin hepsi kitap önerisinde bulunma nedenlerine ilişkin açıklamalarda bulunmuşlardır. Bu durum 1-5 yıl kıdemdeki öğretmenlerin öneride bulunma konusunda diğer kıdemlere göre öğrencilerine daha bilinçli yönlendirmelerde bulunduğunu göstermektedir. Bu kıdemdeki öğretmenlerin kitap önerisinde bulunma nedenlerinde en çok öğrencilerin "bu konuda yardım istemeleri" (\%33,3) etkili olmuştur. 1-5 yıl kıdemdeki öğretmenlerin öğrencilerinin isteklerini ve ihtiyaçlarını dikkate alarak öneride bulundukları söylenebilir. 6-10 yıl ve 11 yıl ve üzeri kıdemdeki öğretmenlerin yanıtlarına bakıldığında ise kitap önerisinde bulunurken öğrencilerinin "okumayı alışkanlık haline getirmelerini" ve "okuma kültürleri açısından çeşitlilik kazanmalarını" önemsemedikleri görülmüştür.

Türkçe öğretmenlerinin kitap önerisinde bulunmama nedenlerine bakıldığında ise; "kendi seçimlerini kendileri yapmaları $(\% 66,6)$ " düşüncesi ile "siyasi ve maddi açıdan yanlış anlaşılmalara neden olabilir $(\% 33,3)$ " düşüncelerinin yer aldığı görülmüştür. Burada dikkat çeken ise sadece 11 yıl ve üzeri kıdemdeki bazı öğretmenlerin bu düşünceler nedeni ile öneride bulunmaktan çekinmesidir. Bulut'un (2018) çalışmasında öğretmenler pek çok yayının yasaklanması nedeniyle sıkıntı yaşadıklarını dile getirmişlerdir. Öğretmenleri bu konudaki görüşleri şöyledir: "Yasaklı bir yayın okulun içine hiçbir zaman giremez. Eskiden okullar yayınevleriyle anlaşıyordu, biz olayın maddi boyutuna karışmıyorduk. Devlet bunu yasakladığından beri zor durumda kalıyoruz." Bu kıdemdeki öğretmenlerin kitap önerme konusunda böyle bir kaygı duymalarının nedeni geçmiş yaşantılarında şahit oldukları olumsuz durumlar ve devletin koyduğu yasaklamalar olabilir. Yine burada 11 yıl ve üzeri kıdemdeki öğretmenlerin mesleki tecrübeleri nedeni ile böyle bir tutum sergiledikleri söylenebilir.

Türkçe öğretmenlerinin önerdikleri kitaplar ile ilgili öğrencileri ile paylaşımda buluma yollarına bakıldığında; "kitap hakkında sohbet ederek $(\% 45,7)$, kitap ile ilgili sorular sorarak $(\% 24,3)$, özet çıkarttırarak $(\% 12,1)$, kitaptan alıntı yaparak $(\% 5)$ ve kitap tanıtımı yaptırarak $(\% 3,6)$ " sınıf içerisinde paylaşımda bulunulduğu görülmüştür. Türkçe öğretmenlerinin en çok "kitap hakkında sohbet ederek" öğrencileri ile paylaşımda bulundukları tespit edilmiştir. Kuş ve Türkyılmaz'ın (2010) öğretmen adayları üzerinde yaptıkları araştırmada, öğretmen adayları okudukları kitabı paylaşma durumları konusunda, en çok "bitirdikten sonra paylaşırım (sohbet ederek/tartışarak) (\%53)" cevabını vermişlerdir. Bu bağlamda her iki çalışmanın da sonuçlarının örtüştügü görülmektedir. Yılmaz'a (2009) göre de öğrencilere eleştirel okuma becerisi kazandırabilmek için okunan kitaplar sınıfta tartışılmalıdır. Öğrencilerin eleştirel okuma becerilerini 
geliştirebilmek için okunan kitapların sınıf ortamında konuşulmasının ve tartışılmasının önemli olduğu sonucunu çıkarılabilir.

1-5 y1l kıdemdeki sınıf ortamında "kitaptan alıntı" yapmadıkları görülmüştür. 6- 10 y1l kıdemdeki öğretmenlerin ise "kitap tanıtımı" yaptırmayı tercih etmedikleri görülmüştür. $\mathrm{Bu}$ bağlamda kıdem boyutunda, kitap paylaşımı konusunda öğretmenlerin farklı uygulamalar yaptıkları söylenebilir.

Öğrencilerin okumaktan en çok hoşlandığı edebi türlere bakıldığında; "hikâye $(\% 28,9)$ roman $(\% 25,1)$, masal $(\% 20,1)$, şiir $(\% 8,4)$, anı $(\% 7,9)$, gezi yazısı $(\% 5,4)$, biyografi $(\% 2,7)$, deneme $(\% 1,1)$ " türleri olduğu görülmüştür. Öğrencilerin "makale" ve "söyleşı" türünü okumayı tercih etmedikleri tespit edilmiştir. Buna göre öğrenciler en çok "hikâye" ve "roman" türlerini okumaktan hoşlandıkları belirlenmiştir. Öğrencilerin de öğretmenler gibi olaya dayalı nesir türlerini okumayı tercih ettikleri sonucuna ulaşılabilir. Deniz (2015) ortaokul öğrencilerinin okuma alışkanlıkları üzerine yaptığı çalışmasında öğrencilerin "roman $(\% 49,2)$, hikâye $(\% 38,8)$, şiir $(\% 4,2)$, deneme $(\% 1,8)$ " türlerini okumaktan hoşlandıklarını belirlemiştir. Temizyürek, Çolakoğlu ve Coşkun'un (2013) 9.sınıf öğrencilerinin okuma alışkanlıkları üzerine yaptıkları araştırmada öğrencilerin "roman (\%66), çizgi roman $(\% 13,6)$, hikâye $(\% 12,2)$, şiir $(\% 5,3)$ " türelerini okumaktan hoşlandıkları belirlenmiştir. Can, Türkyılmaz ve Karadeniz'in (2010) ortaokul ve lise öğrencileri üzerinde yaptıkları araştırmada ise öğrenciler "her zaman roman okurum $(\% 27,6)$, her zaman hikâye okurum $(\% 20,3) "$ demiştir. Bu bağlamda yapılan çalışmalar ile sonuçların örtüştüğü söylenebilir.

Türkçe öğretmenlerinin öğrencilerine hangi amaçlarla kitap okuttuğuna bakıldığında; "okuma sevgisi kazandırabilmek $(\% 20,6)$, anlama ve anlatma becerisini geliştirmesi $(\% 19,3)$, kendisini geliştirmesi $(\% 17,2)$, başarısını arttırmak (\%14,5), keyifli zaman geçirmesi $(\% 13,1)$, edebi haz duyabilmesini sağlamak $(\% 10,6)$, güncel olayları takip edebilmesini sağlamak $(\% 4,3)$ " gibi amaçlar güttükleri görülmüştür. Can, Türkyılmaz ve Karadeniz'in (2010) ortaokul ve lise öğrencileri üzerinde yaptıkları araştırmaya bakıldığında, öğrenciler okuma nedenleri olarak "öğrenmek için $(\% 39,1)$, boş zamanımı değerlendirmek için $(\% 22)$, rahatlamak için $(\% 10,7)$, eğlenmek için $(\% 7)$ " cevaplarını vermişlerdir. Bu bağlamda Türkçe öğretmenlerinin öğrencilerine kitap okutma amaçları ile öğrencilerin kitap okuma amaçları arasında bazı farklılıklar olsa da genel olarak cevapların örtüştüğü görülmüştür. Türkçe öğretmenleri "okuma sevgisi kazandırmak, anlama ve anlatma becerisini geliştirmek, öğrencinin kendisini geliştirmek, başarıyı arttırmak, güncel olayları takip etmek" gibi daha çok faydacı amaçlar ile "keyifli zaman geçirmelerini ve edebi haz duyabilmelerini sağlamak" gibi duyuşsal amaçlar hedeflemişlerdir. Öğrencilerin de yine en çok "öğrenmek için" diyerek faydacı bir amaç güttükleri söylenebilir. Sonrasında "boş zaman değerlendirmek, rahatlamak ve eğlenmek" cevapları ile duyuşsal nedenlerle de kitap okuduklarını göstermektedir.

Öğretmenlerin kitap okutma konusunda faydacı bir anlayış benimsemelerini Ak Başoğul'un yaptığı araştırma sonucu da destekler niteliktedir. Ak Başoğul (2018) çalışmasında Türkçe öğretmenlerinin çocuk edebiyatının ve kitabın öneminin farkında olduğu ve bu durumun okuma kültürü bağlamında olumlu etkiler yarattığı sonucuna ulaşmıştır. Bu bağlamada öğretmenlerin çocuklara fayda sağlaması amacı ile kitap okuttuğu görüşü önem kazanır.

Türkçe öğretmenlerinin okuma konusunda öğrencilerin birbirlerini olumlu etkilemesi için yaptırdığı etkinliklere bakıldığında; "kitap okuma yarışması (\%21,3), sınıfta, kütüphanede, açık havada vb. yerlerde birlikte kitap okuma saati düzenleme $(\% 14,9)$, okunan kitabı sınıfta anlattırma $(\% 11,3)$, kitap tanitım $1(\% 10,6)$, kitap sohbetleri $(\% 8,5)$,birbirine kitap hediye etme $(\% 7,1)$, arkadaşımın kitabını okuyorum etkinliği (\%5,7), okunan kitabı sınıfta canlandırma etkinliği (\%5), kitap kahramanlarını tanıtan görseller hazırlama $(\% 0,7)$, kitabın devamını tahmin etme oyunu $(\% 0,7)$, kitap çekilişi $(\% 0,7)$, kitap kapağı tasarlama $(\% 0,7)$ ” gibi etkinlikler düzenlendiği görülmüştür. Öğretmenlerin en çok okuma yarışması ve birlikte kitap okuma etkinlikleri 
düzenledikleri görülmüştür. Bazı öğretmenlerin soruyu yanıtlamayarak "boş $(\% 12,8)$ " bırakması ise her Türkçe öğretmenin okuma etkinliği yaptırmadığını göstermektedir.

Yaratıcı drama, bireyin birçok yönünü geliştirerek bütün bir öğrenme sağlar. Çocukları harekete, okumaya, rol oynamaya, grup çalışmasına özendirir. Çocukları rollerini araştırma ihtiyacı ile okuma sürecine sokabilir (Adıgüzel, 2009). Bu görüş, okunan kitabın sınıfta canlandırılmasının okumayı olumlu etkileyebileceğini göstermektedir.

Öğretmenlerin öğrencilerin okuma konusunda birbirini olumlu etkileyen etkinlikler düzenlemeleri çocuklar üzerine arkadaş (akran) boyutunun önemini göstermektedir. Ortaokulda ergenlik döneminde olan çocuklar üzerinde arkadaş çevresinin olumlu ya da olumsuz büyük etkileri vardır. Ülper'in (2011) ilköğretim öğrencileri üzerinde yaptığı çalışmada okumanın arkadaş boyutu ile "ara sıra" karşılaştıkları belirtilmiştir. Öğrencilerin çoğu "arkadaşlarımda okuduğumuz kitapları değişiriz, arkadaşlarımı kitap okurken görürüm, arkadaşlarım okudukları kitabı bana önerirler, arkadaşlarım beni okumaya teşvik eder, arkadaşlarım okudukları kitapları bana tanıtır, arkadaşlarım bana kitap hediye eder." ibarelerine "ara sıra" cevabını vermişlerdir. Bu bağlamda iki çalışmada da okuma konusunda arkadaş etkisinin önemli olduğu söylenebilir.

Türkçe öğretmenlerinin okuma ile ilgili yaptıkları etkinliklere bakıldığında öğretmenlerin; "sınıf kitaplığından faydalanılması (\%18), kitap hediye etme $(\% 16,9)$, okul kütüphanesinden faydalanılmasının sağlanması $(\% 16,8)$, kitap okuma ile ilgili proje ödevi verme (\%16)" etkinlik seçeneklerine evet yaparım cevabını vermişlerdir. Yine tablo geneline bakıldığında öğretmenlerin; "kitap fuarlarına götürme $(\% 25,2)$, imza günlerine götürme $(\% 23,2)$, şair ve yazar söyleşilerine götürme $(\% 22,2)$, süreli yayın takibi için teşvik etme $(\% 10,8)$ " etkinlik seçeneklerine ise hayır cevabını verdikleri görülmüştür. Öğretmenlerin okulun sahip olduğu imkanlar ile yapılabilecek etkinlikleri daha çok yaptırdıkları ancak okul dışındaki fuar, imza günleri gibi etkinlikleri daha az yaptırdıkları söylenebilir.

Sınıf ve okul kitaplıklarının kaliteli bir öğrenme ortamının yaratılmasında önemli bir yeri vardır. Öğretmenler çalıştıkları okullarda kitaplık kurma ve zenginleştirme konusunda gerekli çabayı göstermelidir. Öğrencilerine çocuk kitaplıklarından yararlanma yollarını da öğretmelidirler (Kavcar, Oğuzkan ve Sever, 1995). Buna göre öğretmenleri sadece \%18'inin sınıf kitaplığının kullanılmasını sağlamasının çocukların okumalarını etkilemekte yetersiz olduğu söylenebilir.

Konan'ın (2013) çalışmasında okul yöneticilerinin “\%5,7'sinin her firsatta, \%10,6'sının çoğunlukla, \%51,8'inin bazen” öğrencilere kitap hediye ettiği görülmüştür. Öğrencilere hediye olarak kitap verilmesi konusunda idarenin bakış açısı ve maddi desteği çok önemlidir. Öğretmen her zaman kendi maddi imkânları ile kitap satın alamayabilir. Bu bağlamda iki çalışmanın sonuçlarının örtüştüğü söylenebilir. Türkçe öğretmenlerinin sadece \%16,9'unun öğrencilerine hediye olarak kitap vermesinin yetersiz olduğu söylenebilir.

Okul kütüphanesi, öğrencilerin sorumluluk sahibi vatandaşlar olmalarını sağlar, onları yaşam boyu öğrenme becerisiyle donatır ve hayal güçlerini geliştirir. Okul kütüphanesi hizmetleri okulun bütün üyelerine dil, din, yaş, rrk, cins, millet, meslek ve sosyal durum gözetilmeksizin eşit olarak sağlanmalıdır. Kütüphane hizmetlerini kullanamayacak durumda olanlara özel hizmetler sunulmalıdır (IFLA, 1994). Bu bilgi her okulda bir kütüphanenin bulunmasının ve öğrencilerin bu kütüphaneden faydalanmasının ne kadar önemli olduğunu ortaya koymuştur. Türkçe öğretmenlerinin yalnızca \%16,8'inin okul kütüphanesinden faydalanılmasını sağlaması okul kütüphanelerine gereken önemin verilmediğini göstermektedir. Deniz'in (2015) öğrencilerin okul kütüphanelerini kullanma sıklıklarını araştırdığ çalışmasında; "her gün $(\% 8,6)$, haftada bir $(\% 13,4)$, ayda bir $(\% 6,3)$, nadiren $(\% 30,6)$, hiçbir zaman $(\% 41,1)$ ” cevaplarının verildiği görülmüştür. Bu çalışma da okul kütüphanelerinden yeterince faydalanılmadığı sonucunu destekler niteliktedir. 
Öğretmenlerin \%16'sı kitap okuma ile ilgili "proje ödevi veririm” cevabını vermiştir. Öğretmenler bu konuda okumanın ödev olmasının öğrenciyi okumaya karş1 soğuttuğu görüşünü benimsedikleri için bu konuda ödev vermeyi tercih etmediklerini belirtmişlerdir. Bu bağlamda okumanın ödev olmasının öğrenciyi olumsuz etkilediği söylenebilir. Yılmaz'a (2009) göre de öğretmen kitap okuma öğrenciye ödev gibi gösterilmemeli ve bu konuda ölçülü bir zorlama içinde olunmalıdır.

Araştırmaya katılan öğretmenlerin büyük çoğunluğu "öğrencileri kitap fuarına götürür müsünüz?" sorununa "hayır $(\% 25,2)$ " demiştir. Çocuk Vakfının (2006) araştırmalarına göre de ortaokuldaki öğrencilerde fuara gitme alışkanlığı yoktur. Yine aynı şekilde öğretmenlerin çoğu "imza günlerine $(\% 23,2)$ ve şair ve yazar söyleşilerine götürmem $(\% 22,2)$ demiştir. Öğretmenlerin fuar, imza günü, söyleşi gibi etkinliklere öğrencilerini götürmedikleri ya da götüremedikleri sonucuna ulaşılabilir.

Öğrencilerin okuma zevk ve alışkanlıklarını geliştirmelerinde çocuk gazete ve dergilerinin önemli bir yeri vardır. Öğrencilerin yazılı anlatım açısından da iyi yetişmelerine imkân tanıyan sınıf ve okul gazeteleri üzerinde durulmalı, çocuk dergilerinden de yararlanılmaya çalışılmalıdır (Kavcar, Oğuzkan ve Sever, 1995). Öğretmenlerin öğrencilerini süreli yayınlara teşvikinin $(\% 10,8)$ de yetersiz olduğu görülmektedir. Konan'ın (2013) okul yöneticileri ile yaptığı çalışmasında okul yöneticilerinin sadece \%26,2'sinin herhangi bir dergiye abone olduğu, \%73,8'inin hiçbir dergiye abone olmadıkları görülmüştür. Ayyıldız, Bozkurt ve Canlı' nın (2006) öğretmen adayları üzerinde yaptığı çalışmada öğretmen adaylarının sadece \%25,5'inin en az bir tane aylık/haftalık dergi takip ederim dedikleri görülmüştür. $\mathrm{Bu}$ durumda öğretmenlerin de süreli yayınları takip etmediği görülmektedir. Öğretmenlerin öğrencilerini süreli yayınlara teşvik edebilmesi için öncelikle kendilerinin süreli yayınları düzenli olarak takip etmesi gerektiği sonrasında bu konuda öğrencilerine rehberlik yapması gerektiği sonucuna ulaşılabilir.

Öğretmenler fuar, imza günleri, şair ve yazar söyleşileri ve süreli yayınların takibi gibi etkinlikleri çok fazla düzenleyememelerinin nedeni olarak "imkân yetersizliği (maddiyat ve ulaşım), yakın çevrede böyle etkinliklerin yapılmaması, izin almanın zor olması (aile ve MEB)" gibi nedenler belirtmişlerdir. İl merkezinde ve ilçelerde bu tarz etkinliklerin düzenlenmemesi, diğer illerde düzenlenen etkinliklere katılımlarda veli ve MEB kaynaklı izin engelleri ile karşılaşılmasının öğretmenlerin bu tarz etkinlikler düzenlemesine engel olduğu söylenebilir. Bu engeller öğretmenlerin istekleri dışında karşılaştıkları engellerdir. Kalkınma Bakanlığ (2017) tarafından Kop Okuyor Projesi kapsamında gerçekleştirilen Okuma Kültürü ve Farkındalık Çalıştayı'nda okumayla ilgili kırsal kesimlerde sosyokültürel faaliyetler eksikliği sorunu üzerinde durulmuş ve bu sorunun giderilmesi için kitap fuarlarının yapılmasına, çeşitli etkinliklerle okur-yazar buluşmasının sağlanmasına, yerel festivallerde okuma ve kitap ile ilgili etkinliklere yer verilmesine yönelik önerilerde bulunulmuştur.

\section{Öğrencilerin Okumayı Bir Kültür Haline Getirebilmeleri İçin Türkçe Öğretmenlerinin Verdiği Önerilerden Elde Edilen Tespitlere İlişsin Sonuçlar ve Tartışmalar}

Araştırmaya katılan Türkçe öğretmenlerinin öğrencilerinde okuma kültürü oluşturabilmek adına bulundukları önerilere bakıldığında çoğunlukla; "öğrencilerin ilgi alanlarına ve seviyelerine uygun kitaplarla buluşmaları sağlanmalı $(\% 16,2)$, aile bireyleri (anne, baba, kardeşler vb.) rol model olmalı (\%15,7), okuma üzerine etkinlikler (fuarlar, söyleşiler, drama, münazara, imza günleri, kitap günleri vb.) düzenlenmeli $(\% 11,3)$, öğretmen rol model olmalı $(\% 10,3)$ önerileri görülmüştür. Öğretmenlerin ise bir kısmının (\%12,7) soruyu yanıtlamayarak boş bırakmışlardır. Öğretmenlerden bazılarının öğrencilerinde okuma kültürü oluşturabilmek adına öneride bulunmaması; anket sorularına verdikleri cevapları yeterli gördüklerini ve okuma kültürü oluşturma süreci ile ilgili farklı bir fikre sahip olmadıklarını göstermektedir. 
Öğrencilerin okumayı içselleştirmeleri ve bir kültür haline getirebilmeleri adına Türkçe öğretmenleri en çok öğrencilerin ilgi alanlarına ve seviyelerine göre kitaplarla buluşturulması $(\% 16,2)$ gerektiğini düşünmektedir. Yılmaz'a (2009) göre de öğretmen öğrencisinin nasıl bir okuyucu olduğunu ve hangi türleri okumaktan hoşlandığını takip etmeli, öğrencisinin ilgi alanlarını ve düzeyini bilmeli, bu yönde öğrencilerine kitap seçiminde yardım etmelidir.

Öğretmenler; aile bireyleri $(\% 15,7)$ ve öğretmenlerin $(\% 10,3)$ öğrencilere rol model olmas1 gerektiği görüşünü belirtmişlerdir. Deniz'in (2015) çalışmasında ortaokul öğrencilerinin okumalarında en çok "aile $(\% 36,1)$, öğretmen $(\% 25,1)$, arkadaş $(\% 19,9)$, TV-medya $(\% 9,5)$ " unsurlarının etkili olduğu görülmektedir. Yılmaz'ın (2011), Ankara'da yaptığı bir araştırmaya göre okuma konusunda ailenin etkisine bakıldığında ailelerin büyük bölümü $(\% 32,9)$ hiç kitap okumazken, ailede kitap okuyan bireylerde en düşük oran en büyük öneme sahip anne ve babalara $(\% 13,9)$ aittir. Bireylerin kitap okuyup okumamaları konusunda ailelerin çoğunlukla $(\% 65,1)$ tepkisiz ve ilgisiz oldukları görülmüştür. Arıcı'nın (2005) 2000 öğrenci üzerinde yapmış olduğu araştırmada öğrencilerin \%57,3'ü kitap okuma fikrini öğretmeninden aldığını söylemektedir. \%17,9’u annemden görüp alıştım, \%13,4'ü babamdan görüp alıştım, demiştir. Öğrencilerin \%35,4'ü okudukları ilk kitabı öğretmenlerinin verdiğini söylemiştir. Bu araştırma kitap okuma konusunda ailelerin çocuklarına iyi bir model olamadıklarını göstermektedir. Ülper'in (2011) ilköğretim öğrencileri üzerinde yaptığı araştırmasında, öğrencilerin aile boyutuna ilişkin güdüleyici etmenlerle "ara sıra" karşılaştıkları görülmüştür. Öğrencilerin çoğu "ailem çeşitli okuma materyalleri alır, evimizde kitap okuma saatleri belirlenir, ailemi kitap okurken görürüm, ailem okuduklarını anlatır, okuduklarımı anlatmamı ister, ailem beni kitap okumaya teşvik eder, ailem beni okuduğum için över ve kitap armağan eder." ibarelerine "ara sıra" cevabını vermiştir. Bu durum genel olarak ailelerin bu konuda duyarlı olmadığını göstermektedir. Bütün bu araştırmalar çocuklara okuma kültürü edindirmede ailenin ve öğretmenin rol model olmasının önemli olduğunu sonucunu göstermiştir.

Türkçe öğretmenleri illerinde ve ilçelerinde okumaya teşvik edici etkinlikler düzenlenmemesini, öğrencilerde okuma kültürü oluşturabilmek adına bir eksiklik olarak görmeleri nedeniyle okuma üzerine etkinlikler (fuarlar, söyleşiler, drama, münazara, imza günleri, kitap günleri vb.) düzenlenmeli $(\% 11,3)$ önerisinde bulunmuşlardır. Bu durum öğretmenlerin aslında bu tarz etkinliklere öğrencilerini dahil etmek istediğini ancak imkân yetersizliği nedeniyle dahil edemediklerini göstermektedir. Fuar, söyleşi gibi etkinliklere öğrencilerin dahil edilmesi konusunda okul idaresi, il ve ilçe milli eğitim müdürlükleri de destek olmalı, bütün illerde bu tarz etkinliklerin düzenlenmesi sağlanmalıdır. Ayrıca sınıf içerisinde canlandırma, drama gibi çalışmaların da okumayı olumlu etkilediği söylenebilir. Bulut'un (2018) çalışmasında öğretmenler, çocukların ilgisini çekmek için canlandırma, ses tonunu kullanma yollarını izlediklerini söylemişlerdir.

Öğretmenlerin \%6,9’u okumanın faydaları öğrencilere anlatılmalıdır önerisinde bulunmuştur. Yalman, Özkan ve Kutluca' nın (2013) eğitim fakültesi öğrencileri üzerinde yaptıkları araştırmada, okumanın faydaları "sözcük hazinemi arttırır $(\% 27,2)$, kendime güven duymamı sağlar $(\% 25,4)$, diğer insanlardan kültürlü olmamı sağlar $(\% 20,9)$, hayal dünyamı geliştirir $(\% 20,9)$, toplumda takdir edilmemi sağlar $(\% 5,4)$ " olarak belirlenmiştir. Okumanın faydalarının anlatılması öğrenciyi okumaya teşvik edecektir sonucuna ulaşılabilir.

Öğretmenler okuma sevgisi ve alışkanlığının erken yaşta kazandırılmasını $(\% 2,5)$ önemi üzerinde durmuşlardır. Sever ve diğerleri (2013) okuma kültürünün oluşmasının ve gelişmesinin okulöncesi dönemde okuma sevgisi ve bilincinin kazandırılmasına bağlı olduğunu belirtmişlerdir. Fırat ve Coşkun'un (2017) çalışmasında öğretmen adaylarının okuma alışkanlığı kazanılması gereken döneme ilişkin görüşlere bakıldığında; adayların \%63,7'si ilkokul, \%21'i okulöncesi, $\% 15,3$ 'ü ise ortaokul döneminde kazanılması gerektiği cevabını vermişlerdir. Bu bağlamda okuma sevgisi ve alışkanlığının erken yaşlarda kazandırılmasının okuma kültürünün oluşmasında önemli bir etken olduğu söylenebilir. 
Öğretmenler kitap fiyatları düşürülmeli (\%2) önerisinde bulunmuşlardır. Bulut’un (2018) 30 öğretmen üzerinde yaptığı araştırmasında öğretmenlerin "Zaten okulun ekonomik gücü yok. Son yıllarda pek kitap alamadık. Evden getirdiğimiz kitapları koyduk kitaplığa. Çocuklar da getiriyor bazen. O kitaplar da seviyenin üstünde ya da çok altında olabiliyor." dedikleri görülmüştür. Bu durum kitap fiyatlarının okumayı olumsuz etkilediğini göstermektedir.

Öğretmenler her evde kitaplık bulunmalı $(\% 0,5)$, kütüphane kullanımı kültür haline getirilmeli $(\% 0,5)$, kitaplık ve kütüphaneler güncellenmeli $(\% 0,5)$ önerilerinde bulunmuşlardır. Yılmaz (2009) öğretmenin sınıfta iyi ve işlevsel bir sınıf kitaplığı oluşturması gerektiğini söyler. Kurnaz ve Yıldız (2015) ortaokul öğrencileri üzerinde yaptıkları araştırmada evde kitaplık bulunmasının öğrencilerin okuma motivasyonunu olumlu yönde etkilediğini tespit etmişlerdir. Yılmaz' a (2004) göre bir çocuğun okuma ve kütüphane kullanma alışkanlığını kazanmasında ve geliştirmesinde etkili birçok bireysel ve toplumsal etmen vardır. Bu etmenler: ülkenin kültür yapısı, eğitim sistemi, düşünce özgürlüğü, medya gibi toplumsal etmenlerin yanı sıra aile, öğretmen, kütüphaneci, arkadaş grubu gibi yakın çevrenin etkisi gibi etmenlerdir. Özellikle öğretmen kütüphaneci iletişimi bu bakımdan çok önemlidir. Manguel'e (2002) göre her insanın bir okuma kategorisi vardır. Fakat kategoriler kısıtlayıcıdır ve okuma değildir. Nasıl bir sınıflandırma yapılmış olursa olsun, kütüphane okuma eylemini baskı altına alır ve okuru dikkatli-tetikte olan okuru kendi kategorisinden kurtarmaya zorlar. Kütüphane kullanımının önemi üzerinde bu kadar durulmasına rağmen kütüphane kullanımı konusunda az sayıda öğretmenin öneride bulunmuş olması, öğretmenlerin okuma kültürü oluşturma sürecinde kütüphanenin önemini kavramamış olduklarını göstermektedir. Kültür ve Turizm Bakanlığının (2011) hazırladığı Türkiye Okuma Kültürü Haritasına göre halk kütüphanelerinin varlığı biliniyor (\%77) ancak genellikle halk kütüphanelerinden yararlanma ihtiyacı duyulmuyor.

\section{Öneriler}

Okuma kültürü oluşum sürecinin başarılı olabilmesi için uygulayıcılara (devlet, eğitim kurumları, öğretmenler) yönelik olarak: Okumayı farklı yöntem ve tekniklerle sevdirmeyi sağlayacak kurslar açılabilir, kütüphane sayıları arttırılabilir, kütüphaneler zenginleştirilebilir ve daha ilgi çekici hale getirilebilir, kütüphanelerdeki, okullarda kitaplık ve kütüphaneler için ek bütçeler ayrılabilir, farklı mekanlarda (otobüs, metro, hapishane, parklar vb.) okuma alanları oluşturulabilir, ülke genelinde kitap fuarları, imza günleri, yazar ve şair söyleşileri düzenlenmesi sağlanabilir, kitap vergileri ve fiyatları düşürülebilir, televizyon dizilerinde okumayı özendirici sahnelere yer verilebilir, okuma sevgisi aşılayan ve okumaya özendiren belgeseller çekilebilir, toplumda okuyan bireylerin toluma faydaları vurgulanabilir, ailelere çocuklarını okuma konusunda nasıl eğitebileceklerini anlatan seminerler düzenlenebilir, Türkçe öğretmenleri okuma kültürü oluşturabilmek adına farklı etkinlikler düzenleyebilir. Araştırmacılara yönelik olarak ise: Kütüphane kullanımının okuma kültürü oluşturma sürecindeki önemi dikkate alınarak kütüphane kullanımının okuma kültürü oluşturma sürecine etkisini araştıran çalışmalar yapılabilir. Çalışma okuma kültürünün erken yaşlarda ailede oluşmaya başladığını göstermiştir. Bu bağlamda ailelerin çocuklarında okuma kültürü oluşturabilmek adına yapabileceklerini araştıran çalışmalar yapılabilir. Çalışmada okuma ortaokul düzeyinde öğrencilerin okuma kültürü oluşturmuş olmalarının gerektiği görülmüştür. Ortaokul öğrencilerinin okuma kültürü oluşturup oluşturmadığı araştırılabilir ve öğrenciler üzerinden okuma kültürü oluşturabilmek için yapılacaklar araştırılabilir önerilerinde bulunulabilir. 


\section{Kaynakça}

Adıgüzel, H. Ö. (2009). Yaratıcı dramanın dramatizasyon, rol içinde yazma ve rol kartları tekniklerinin okuma kültürü ile ilişkisi. Çocuk ve Okuma Kültürü Sempozyumu. 24-25 Mayıs 2008. Eğitim Sen Yayınları.

Ak Başoğul, D. (2018). Türkçe ögretmenlerinin ve önerdikleri kitapların söylemleri bağlamında okuma kültürü anlayışı: bir durum çalışması, [Yayımlanmamış yüksek lisans tezi]. Marmara Üniversitesi, Eğitim Bilimleri Enstitüsü.

Arı, E. \& Demir, M. K. (2013). İlköğretim bölümü öğretmen adaylarının kitap okuma alışkanlıklarının değerlendirilmesi. Anadili Ĕ̆itimi Dergisi, 1(1), 116-128. $\quad$ Erişim adresi http://www.anadiliegitimi.com/download/article-file/14890

Arıcı, A. F. (2005). İlköğretim ikinci kademe ögrencilerinin okuma durumları, [Yayımlanmamış doktora tezi]. Atatürk Üniversitesi, Sosyal Bilimler Enstitüsü.

Ayyıldız, M., Bozkurt, Ü. \& Canlı, S. (2006). Okuma kültürü üzerine bir araştırma. Milli Eğitim Dergisi, 34(169), 277-296. Erişim adresi http://dhgm.meb.gov.tr/yayimlar/dergiler/milli_egitim_dergisi/169/mustafa.pdf

Bulut, S. (2018). Okulöncesi eğitim ortamlarında çocuk kitaplarıyla gerçekleştirilen uygulamaların okuma kültürü edindirme bağlamında incelenmesi, [Yayımlanmamış yüksek lisans tezi]. Ankara Üniversitesi, Eğitim Bilimleri Enstitüsü.

Bulut, Z. (2011, Ocak). Öğretmen ve öğrenci okuma alışkanlıkları. Okuma Kültürü̈ Sorunlar ve Çözüm Yolları Sempozyumu, 55-75. Eğitim Sen Yayınları.

Can, R., Türkyılmaz, M. \& Karadeniz, A. (2010). Ergenlik dönemi öğrencilerinin okuma alışkanlıkları. Ahi Evran Üniversitesi Eğitim Fakültesi Dergisi, 11(3), 1-21. Erişim adresi http://dergipark.gov.tr/aeukefd/issue/1412/16923

Çocuk Vakfi, (2006). Türkiye'nin okuma alışkanlığı karnesi. Erişim adresi http://cocukvakfi.org.tr/wpcontent/dosya/raporlar/13_okuma_aliskanligi_karnesi2006.pdf

Deniz, E. (2015). Ortaokul öğrencilerinin kitap okuma alışkanlıkları. Okuma Yazma Eğitimi Araştırmaları, 3(2), 46-64. Erişim adresi http://www.rrwi.org/article/view/5000166532

Francois, C. (20r11). The social dimensions of an individual act: situating urban adolescent students reading growth and reading motivation in school culture, (Unpublished Doctorial Dissertation). Harvard University.

Fırat, H. (2017). Türkçe öğretmeni adaylarının bölümde okumaya başladıktan sonra kitap okuma durumlarında meydana gelen değişimler. Turkish Studies- International Periodical for the Languages, Literature and History of Turkish or Turkic, 12(4), 193-216. doi: 10.7827/TurkishStudies.11298

Fırat, H. \& Coşkun, M. V. (2017). Türkçe öğretmeni adaylarının kitap okuma kültürü: Muğla Sitkı Koçman Üniversitesi örneği. Eğitim Bilimleri Araştırma Dergisi, 7(1), 145-162. Erişim adresi ebad- jesr.com/images/MAKALE_ARSIV/C7_S1makeler/5.7.1.TR.pdf

Gündüz, O. \& Şimşek, T. (2011). Uygulamalı okuma eğitimi (anlama teknikleri 1). Grafiker Yayınları.

Güneş, F. (2017). Türkçe ögrretimi yaklaşımlar ve modeller (5. Baskı). Pegem Akademi Yayınları.

IFLA/UNESCO, (1994). Okul kütüphanesi bildirgesi. Erişim adresi http://kutuphaneci.org.tr/bildirgeler/ifla-unesco-okul-kutuphanesi-bildirgesi/ 
İnce Samur, Ö. (2014). “Bireye” okuma kültürü edindirme izlencesi, (Yayımlanmamış Doktora Tezi). Ankara Üniversitesi, Eğitim Bilimleri Enstitüsü.

İnce Samur, Ö. (2016). Okuma kültürü nasıl kazandırılır? Anı Yayınc1lık.

İpek Eğilmez, N. \& Özşavli, G. (2018). Kitap okumaya yönelik tutum ölçeğinin geliştirilmesi: geçerlik ve güvenirlik çalışması. Turkish Studies Educational Sciences, 13(11), 727-744. doi: http://dx.doi.org/10.7827/TurkishStudies.13165

Kalkınma Bakanlığı, (2017). KOP Okuyor Projesi, Okuma kültürü ve farkındalık çalıştayı sonuç raporu (6-7 Ekim). Erişim adresi http://kopsosyal.kop.gov.tr/haber/okuma-kulturu-vefarkindalik- calistayi-sonuc-raporu/9

Karasar, N. (1999). Bilimsel araştırma yöntemi. Nobel Yayınları.

Kasap, B. (2019). Yaratıcı okuma-yaratıcı yazma çalışmalarının yaratıcı okuma, okuduğunu anlama, yazma ve yaratıcı yazma erişisine etkisi, [Yayımlanmamış doktora tezi]. Pamukkale Üniversitesi, Eğitim Bilimleri Enstitüsü.

Kavcar, C., Oğuzkan, F. \& Sever, S. (1995). Türkçe öğretimi. Engin Yayınevi.

Konan, N. (2013). İlköğretim okulu yöneticilerinin okuma alışkanlıkları. Kuram ve Uygulamada Ë̆itim Yönetimi, $19(1), \quad 31-59 . \quad$ Erişim http://www.kuey.net/index.php/kuey/article/view/958

Körkuyu, S. (2014). Okuma kültürü edindirme sürecini etkileyen temel değişkenlerin incelenmesi, [Yayımlanmamış yüksek lisans tezi]. Ankara Üniversitesi, Eğitim Bilimleri Enstitüsü.

Kurnaz, H. \& Yıldız, N. (2015). Ortaokul öğrencilerinin okuma motivasyonlarının çeşitli değişkenlere göre değerlendirilmesi. Türkiye Sosyal Araştırmalar Dergisi, 19(3), 53-70. Erișim adresi https://s3.amazonaws.com/academia.edu.documents/41635406/2._ORTAOKUL_OGREN CILERININ_OKUMA_MOTIVASYONLARI.pdf

Kuş, Z. \& Türkyılmaz, M. (2010). Sosyal bilgiler ve Türkçe öğretmeni adaylarının okuma durumları: (ilgi, alışkanlık ve okuma stratejilerini kullanım düzeyleri). Türk Kütüphaneciliği, 24(1), 11 32. Erişim adresi http://www.tk.org.tr/index.php/TK/article/viewFile/503/496

Kültür ve Turizm Bakanlığı, (2011). Türkiye okuma kültürü haritası. Erişim adresi http://www.kygm.gov.tr/Eklenti/55,yonetici-ozetipdf.pdf?0

Manguel, A. (2002). Okumanın tarihi (2. Bask1), çev., Elioğlu, F. Yapı Kredi Yayınları.

M.E.B. Ölçme Değerlendirme ve Sinav Hizmetleri Genel Müdürlüğü, (2015). PISA 2015 ulusal raporu. Erişim adresi http://pisa.meb.gov.tr/wpcontent/uploads/2014/11/PISA2015_UlusalRapor.pdf

Miles, M. B., Huberman, A. M. (2015). Genişletilmiş bir kaynak kitap: nitel veri analizi, çev., Akbaba Altun, S., Ersoy, A. Pegem Akademi Yayınları.

OKUYAY, (2019). Türkiye Okuma Kültürü Araştırması. Erişim adresi http://okuyayplatformu.com/wp-content/uploads/2020/02/okuma-kulturu-arastirmasi.pdf

Özkaya, P. G. \& Çetin, D. (2014). Türkçe öğretmeni adaylarının okuma alışkanlıkları ve kütüphane kullanımlarına ilişkin bir inceleme (Muğla Sitkı Koçman Üniversitesi Eğitim Fakültesi Örneği). Muğla Sıtkı Koçman Üniversitesi Eğitim $\quad$ Fakültesi Dergisi, 1(1), 1121. Erişim adresi http://www.edergi.mu.edu.tr/index.php/efdergi/article/view/17/10 
Sever, S. (2007). Okuma kültürü edinme sürecinde Türkçe öğretiminin sorumluluğu. Okuma Kültürü ve Okullarda Uygulama Sorunları Toplantısl, 108-126. MEB Yayınları.

Sever, S. (2010). Çocuk ve edebiyat. Tudem Yayınc1lık.

Sever, S., İnce Samur, Ö., Doğan, B. N., Çıldır, B. \& Bulut, S. (2013, Kasım). İlkokul 4. sınıf öğrencilerinin okuma kültürü edinme düzeyleri ile kitle iletişim araçlarını kullanma alışkanlıklarının incelenmesi. 1. Çocuk ve Medya Kongresi, C.1, 371- 397.

Temizyürek, F., Çolakoğlu, B. K. \& Coşkun, S. (2013). Dokuzuncu sınıf öğrencilerinin okuma alışkanlıklarının bazı değişkenlere göre incelenmesi. Türk Eğitim Bilimleri Dergisi, 11(2), 114-150. Erişim adresi http://dergipark.gov.tr/tebd/issue/26092/274942

Ungan, S. (2008). Okuma Alışkanlığımızın kültürel altyapısı. Gaziantep Üniversitesi Sosyal Bilimler Dergisi, 7(1), 218-228. Erişim adresi http://dergipark.gov.tr/download/articlefile/223512

Ülper, H. (2011). Öğrencilerin, okumaya isteklendirici etmenlerle karş1laşma durumu: öğretmen, aile, arkadaş ve kitap boyutları üzerinden bir araștırma. Buca Eğitim Fakültesi Dergisi, 30,

Erișim adresi http://acikerisim.deu.edu.tr/xmlui/bitstream/handle/20.500.12397/146/pdf_124.pdf?sequen $\mathrm{ce}=1 \&$ isAllowed $=\mathrm{y}$

Yalman, M., Özkan, E. \& Kutluca, T. (2013). Eğitim fakültesi öğrencilerinin kitap okuma alışkanlıkları üzerine betimsel bir araştırma: Dicle üniversitesi örneği. Bilgi Dünyası, 14(2), 291-305. Erişim adresi http://bd.org.tr/index.php/bd/article/view/379

Yıldırım, A. \& Şimşek, H. (2005a). Sosyal bilimlerde nitel araştırma yöntemleri. Seçkin Yayınları.

Yıldırım, A. \& Şimşek, H. (2005b). Sosyal bilimlerde nitel araştırma yöntemleri. Eğitimde Kuram ve Uygulama, 2(2), 113-118. Erişim adresi http://dergipark.gov.tr/download/articlefile/63326

Yılmaz, B. (2004). Öğrencilerin okuma ve kütüphane kullanma alışkanlıklarında ebeveynlerin duyarlılı̆̆ı. Bilgi Dünyasl, 5(2), 115-136. Erişim adresi http://bd.org.tr/index.php/bd/article/view/229

Yılmaz, B. (2009, Mayıs). Çocuklarda okuma kültürünü geliştirmede ebeveyn ve öğretmenin rolü. Çocuk ve Okuma Kültürü Sempozyumu, 133-141. Eğitim Sen Yayınlar1.

Y1lmaz. B. (2011, Ocak). Okuma kültürü: Ankara örnekliğinde sosyolojik bir yaklaşım. Okuma Kültürü Sorunlar ve Çözüm Yolları Sempozyumu, 18-33. Eğitim Sen Yayınları.

\section{Beyan ve Açıklamalar (Disclosure Statements)}

1. Araştırmacıların katkı oranı beyanı / Contribution rate statement of researchers: Birinci Yazar/First author \%60, İkinci Yazar/Second author \%40

2. Yazarlar tarafından herhangi bir çıkar çatışması beyan edilmemiştir (No potential conflict of interest was reported by the authors). 